<special sorts: $\{\#\}$ (space); flat sign ( $\{\mathrm{fl}\}$ in file); sharp sign ( $\{\mathrm{sh}\}$ in file); natural sign ( $\{$ na $\}$ in file); double flat sign ( $\{2 \mathrm{fl}\}$ in file [these flats are close together, not spaced]); mensuration sign cut-C $(\{\mathrm{C} /\}$ in file; see $\mathrm{pdf}>$

<running heads: John T. Brobeck | A Music Book for Mary Tudor, Queen of France> Early Music History (2016) Volume 35. (c) Cambridge University Press doi: $10.1017 / \mathrm{S} 0261127916000024$

JOHN T. BROBECK

Email: brobeck@email.arizona.edu

\title{
A MUSIC BOOK FOR MARY TUDOR, QUEEN OF FRANCE
}

Frank Dobbins in memoriam

In 1976 Louise Litterick proposed that Cambridge, Magdalene College, Pepys Library MS 1760 was originally prepared for Louis XII and Anne of Brittany of France but was gifted to Henry VIII of England in 1509. That the manuscript actually was prepared as a wedding gift from Louis to his third wife Mary Tudor in 1514, however, is indicated by its decorative and textual imagery, which mirrors the decoration of a book of hours given by Louis to Mary and the textual imagery used in her four royal entries. Analysis of the manuscript's tabula and texts suggests that MS 1760 was planned by Louis's chapelmaster Hilaire Bernonneau (d. 1524) at the king's behest. The new theory elucidates the content and significance of Gascongne's twelve-voice canon Ista est speciosa, which appeared beneath an original portrait of Mary Tudor and was intended to mirror the perfection of the Blessed Virgin and her 'godchild' Mary.

Although there is general agreement within the scholarly community that the well-known music manuscript Cambridge, Magdalene College, Pepys MS 1760 was created at the French royal court during the first two decades of the sixteenth century, scholars have not been able to agree about the specific circumstances that inspired its creation. ${ }^{1}$ The manuscript (which

1 A facsimile edition of Pepys MS 1760 was published by Howard Mayer Brown in 1988 as volume 2 in his series Renaissance Music Sources in Facsimile (New York: Garland, 1988- ). 
was part of the personal library of the English naval administrator, diarist, musician and bibliophile Samuel Pepys, 1633-1703, and contains his bookplates on the front and back flyleaves) gives every appearance of having been created either for the personal use of a monarch or as an expensive gift to a member of the nobility. At a mere $222 \mathrm{~mm}$. by $147 \mathrm{~mm}$. it is one of the smallest of the nearly 3,000 volumes in the Pepys Library. ${ }^{2}$ Because of its original gold cloth covers it is one of only twenty-two volumes for which Pepys did not provide his own full leather binding, but rather added a partial leather binding covering just the spine of the manuscript to make it resemble the other volumes in his collection. Every page of the parchment manuscript possesses illuminated majuscules or other fine artwork, most prominently on folios $\mathrm{I}^{\mathrm{v}}$ and $\mathrm{II}^{\mathrm{r}}$, whose borders are completely covered in depictions of flora and fauna set against a gold background. There are no obvious cancellations or corrections in the manuscript, which appears to have been copied by one hand (unless the text and music scribes are different). ${ }^{3}$

More recently the manuscript has been published online in colour by the Digital Image Archive of Medieval Music (DIAMM), which may be seen at http://www.diamm.ac.uk/jsp/Descriptions?op=SOURCE\&sourceKey=1671\#imageList. The images are used here by permission of the Pepys Library, Cambridge University. Much of the relevant scholarly literature pertaining to the dating and provenance of the manuscript is identified in its entry in the Census-Catalogue of Manuscript Sources of Polyphonic Music 1400-1550, Renaissance Manuscript Studies, 1, gen. ed. C. Hamm, University of Illinois Musicological Archives for Renaissance Manuscript Studies, 5 vols. (Neuhausen-Stuttgart: American Institute of Musicology/Hänssler-Verlag, 1979-88). All music manuscripts mentioned in this article are cited according to their sigla in the Census-Catalogue. The sigla of printed books refers to the listing in Recueils imprimés $X V I^{e}-X V I I e$ siècles, ed. F. Lesure (Répertoire international des sources musicales; Munich-Duisberg, 1960).

2 The Pepys Library at Magdalene College, Cambridge is of considerable importance for scholars in many disciplines, and has been widely discussed in the scholarly literature. The entire contents of the library are exhaustively catalogued and described in Pepys Library, Catalogue of the Pepys Library at Magdalene College, Cambridge, gen. ed. R. Latham, 7 vols. (Cambridge, 1978-92). The principal description of MS 1760 is in volume 4 of this series. An earlier published catalogue of the portion of the collection including Pepys 1760 appears in M. R. James, Bibliotheca Pepysiana: A Descriptive Catalogue of the Library of Samuel Pepys, Part 3, Mediaeval Manuscripts (London, 1923). A pictorial introduction to the Pepys Library and a useful discussion of its history appears in A. Hobson, Great Libraries (New York, 1970), pp. 213-21.

3 It is not clear if the music and text were written by the same or different scribes. All the music appears to have been copied by a single hand, and all the texts appear to have been copied by a single hand, but the music clefs clearly were written with a pen having a wider nib than the pen used for the texts (my thanks to Bonnie Blackburn for pointing this out). The text hand used throughout the MS includes elements found in both bâtarde handwriting and humanistic book script. Humanistic elements include, among others, straight-backed d; use of tall s; roundness of aspect, well separated letters; use of two compartment g; and the use of the ct ligature. For examples of batârde and humanistic book scripts, see M. P. Brown, A Guide to Western Historical Scripts from Antiquity to 1600 (London, 1990), pp. 108-11, 126-7, and 130-1. Iain 
That MS 1760 originated at the French royal court is strongly suggested by its musical content, since the great majority of its fifty-seven chansons and motets can be attributed to musicians who worked for one or more of three royal patrons, King Louis XII of France (r. 1498-1515), his queen Anne of Brittany (r. 1491-1514) and King Francis I of France (r. 1515-47) (see Table 1 and the complete concordance for MS 1760 in Appendix I). Over half the compositions in the manuscript can be assigned to either Antoine de Févin or Mathieu Gascongne. Févin served as a priest and singer for King Louis XII from at least 1506 until his death in late 1511 or early 1512 . That he was a particular favourite of the king is suggested by a letter written by Louis on 18 April 1507 from Asti, Italy to his friend Guillaume de Montmorency in France to request that a chanson of Févin's and a portrait painted by the court painter Jean Perréal (c. 1450-c. 1530) be sent to him. ${ }^{4}$ Gascongne’s only documented professional affiliation was with the French royal court, and several of his motets published in Pierre Attaingnant's 1534-5 series of motet prints contain textual references suggesting that he was an intimate of the court during the second decade of the century, after Févin's death. ${ }^{5}$ Curiously, however, he was not one of the thirty singers in Louis XII's or Anne of Brittany's chapels who were named in papal supplications between

Fenlon stated that MS 1760 was written by a single hand throughout in his description of the manuscript in Cambridge Music Manuscripts, 900-1700 (Cambridge, 1982), pp. 123-6. He described the script as 'a finely formed bâtarde hand'.

4 The most thorough analysis in print of the meagre evidence pertaining to Févin's biography and the de Févin family of Arras remains E. Clinkscale, 'The Complete Works of Antoine de Févin' (Ph.D. diss., New York University, 1965), pp. 1-25. Archival evidence placing Févin in Blois in 1506 appeared in T. Dumitrescu, 'The Chapel Musicians of Louis XII and Anne de Bretagne at Blois: New Documents, New Singers, and a Prioris Problem', paper presented at the Annual Meeting of the American Musicological Society, Québec City (Nov. 2007).

5 For example, his motet Caro mea vero est cibus appears to have been composed in 1512-13 as a royal response to Louis XII's excommunication by Pope Julius II; Christus vincit Christus regnat sets a version of the Laudes regiae, a text recited at Francis I's coronation in Jan. 1515; and the militaristic text of Deus regnorum, which begs God to give peace and 'da servo tuo Francisco regi nostro de hoste triumphum' may well have been inspired by Francis's victorious Italian campaign of 1515-16. Concerning Caro mea see J. T. Brobeck, 'Style and Authenticity in the Motets of Claudin de Sermisy', Journal of Musicology, 16 (1998), pp. 26-90. For discussion of the style of Gascongne's motets and an alphabetical list of concordant sources by piece see Brobeck, 'The Motet at the Court of Francis I' (Ph.D. diss., University of Pennsylvania, 1991), pp. 467-91. M.A. Colin, 'The Motets of Mathieu Gascongne: A Preliminary Report', in T. Schmidt-Beste (ed.), The Motet around 1500: On the Relationship of Imitation and Text Treatment? (Turnhout, 2012), pp. 335-81 provides a detailed discussion of the motet texts and an updated list of concordant sources that is arranged chronologically. 
1509 and 1514, ${ }^{6}$ nor does he appear in a well-known list of royal chapel singers who performed for Louis XII's funeral and obsequies in January $1515 .^{7}$ The only archival notices mentioning the composer date from 1517-18, when he was listed near the head of a yearly payment roster of royal chapel singers, in several documents pertaining to the SainteChapelle du Palais in Paris, and in a papal supplication that identifies him as one of the king's singers. ${ }^{8}$

Of the other composers cited in MS 1760, Josquin's tenure at the royal court is both more problematic and somewhat earlier, though its significance for the dating and provenance of the Pepys MS is minimised by the extremely broad dissemination of his works and the fact that all five of his pieces in the Pepys manuscript (the five motets of the cycle $O$ admirabile commercium) consistently circulated together during the sixteenth century. ${ }^{9}$ Prioris (Denis Prieur), Jean Mouton and Jean Richafort demonstrably served the royal court during the first two decades of the century, and although Robert de Févin is not known to have been in royal service, he can be linked to the court through his brother Antoine de Févin. ${ }^{10}$ Antoine Brumel worked at Notre Dame in Paris from 1498 to 1500 and was described as 'dudum cantoris regii' (recently a singer of the king) in a document from the court of Savoy dated 1 June 1501. ${ }^{11}$ Louis l'Ormeau dit Bontemps was in regular contact

6 R. Sherr, 'The Membership of the Chapels of Louis XII and Anne de Bretagne in the Years Preceding their Deaths', Journal of Musicology, 6 (1988), pp. 60-82.

7 A corrected transcription of the names in the 1515 chapel list was first presented in Brobeck, 'The Motet', 17; additional discussion in Brobeck, 'Musical Patronage in the Royal Chapel of France under Francis I (r. 1515-1547)', Journal of the American Musicological Society, 48 (1995), pp. 187-239. The unnamed maître de chapelle in the 1515 compte was correctly identified as Hilaire Bernonneau by Cristelle Cazaux in La Musique à la cour de François I ${ }^{\text {er }}$ (Paris, 2002), pp. 71, 343.

8 The 1517-18 chapel list was first described in Brobeck, 'The Motet', pp. 9-30, and is discussed and transcribed in Brobeck, 'Musical Patronage', pp. 190-201, 236-38. The chapel list is also transcribed in Cazaux, La Musique, pp. 237-39. Documents pertaining to Gascongne from the Sainte-Chapelle appear in M. Brenet, Les Musiciens de la Sainte-Chapelle (Paris, 1910, repr. Geneva, 1973), pp. 69-71. Concerning Gascongne’s papal supplication, see Sherr, 'The Membership of the Chapels', p. 81.

9 The most complete summary of musical and archival evidence pertaining to Josquin's biography appears in D. Fallows, Josquin (Centre d'études supérieures de la Renaissance, Collection Épitome musical; Turnhout, 2009), passim.

10 Concerning Prioris, see T. Dumitrescu, 'Who was Prioris? A Royal Composer Recovered', Journal of the American Musicological Society, 65 (2012), pp. 5-65. For biographical information and scholarly literature on Mouton, Richafort and Robert de Févin, see the articles in Grove Music Online.

11 M.-T. Bouquet, 'La cappella musicale dei duchi di Savoia dal 1450 al 1500', Rivista Italiana di Musicologia, 3 (1968), pp. 233-85. See also C. Wright, 'Antoine Brumel and Patronage at 
with numerous royal chapel singers in Blois between 1494 and $1508 .^{12}$ And recent scholarship has tended to credit Il mest advis que je voy perrichon (fols. LXVII $-\mathrm{LXVIII}^{\mathrm{r}}$ of MS 1760) to Hilaire Bernonneau, who served as the chapelmaster of the king's chapel from 1510 to 1515, notwithstanding a late attribution to Antoine de Févin in HerdF 9821. ${ }^{13}$

Only five pieces are attributed in MS 1760 to composers not known to have been directly associated with the French royal court. The composer of one of these, Pierrequin de Thérache, served from 1492 to 1527 at the ducal court of Lorraine, which maintained close ties with the royal court during the first two decades of the sixteenth century. ${ }^{14}$ Moreover, the scholarly literature generally credits Antoine de Févin and not Ninot le Petit with the authorship of J'ayme bien mon amy (fols. LXII - LXIII'), a work attributed to Févin both in the table of contents and by one of the scribes who entered attributions into the body of the manuscript. Ultraviolet inspection of the attribution to le Petit given above the music on fol. LXII ${ }^{\mathrm{v}}$ reveals that it was written over an original attribution to 'Anth. de fevin' that was

Paris', in I. Fenlon (ed.), Music in Medieval and Early Modern Europe: Patronage, Sources and Texts (Cambridge, 1981), pp. 37-60.

12 Archival documents placing this musician at the church of St-Sauveur in Blois, along with numerous other members of the royal chapel who held benefices there, are described in Dumitrescu, 'The Chapel Musicians'.

13 In 1971 Edward Lowinsky suggested that the composer 'Hyllayre’ was Hilaire Penet (b. 1501), a view countered by Lawrence F. Bernstein, who argued that the composer in MS 1760 was the Ferrarese singer Hilaire Tuleron (Lowinsky, ‘A Music Book for Anne Boleyn’, in J. G. Rowe and W. H. Stockdale (eds.), Florilegium historiale: Essays Presented to Wallace K. Ferguson (Toronto, 1971), pp. 161-235, at pp. 162-4 (repr. in E. E. Lowinsky, Music in the Culture of the Renaissance, ed. B. J. Blackburn (Chicago, 1989), pp. 483-538, at pp. 484-5); and Bernstein, 'La Courone et fleur des chansons a troys: A Mirror of the French Chanson in Italy in the Years between Ottaviano Petrucci and Antonio Gardano', Journal of the American Musicological Society, 26 (1973), p. 8, n. 31). Given the heavily French royal court orientation of the music in MS 1760, more recent scholarship has pointed to Hilaire Bernonneau as the author of this chanson. See Sherr, 'The Membership of the Chapels', pp. 61-4; Brobeck, 'The Motet', pp. 5778; Brobeck, 'Musical Patronage', pp. 196-8, 238-9; Cazaux, La Musique, pp. 342-3; Dumitrescu, 'Chapel Musicians', and Dumitrescu, 'Who was Prioris', 53-4. Il mest advis que je voy perrichon is attributed to 'Antho. Fevin' in HerdF 9821, fols. [281 ${ }^{\mathrm{v}}-282^{\mathrm{v}}$ ]. The most complete analysis of the Herdringen manuscript appears in D. Fallows, 'The Content of the Herdringen Scores', in M. J. Bloxom, G. Filocamo, and L. Holford-Strevens (eds.), Uno gentile et subtile ingenio: Studies in Renaissance Music in Honor of Bonnie J. Blackburn (Centre d'études supérieures de la Renaissance, Collection Épitome musical; Turnhout, 2009), pp. 217-32.

14 On links between the ducal court of Lorraine and the French royal court, see R. Freedman, 'Music, Musicians, and the House of Lorraine during the First Half of the Sixteenth Century' (Ph.D. diss., University of Pennsylvania, 1987), and Freedman, 'The Chansons of Mathieu Lasson: Music at the Courts of Lorraine and France ca. 1530’, Journal of Musicology, 8 (1990), pp. 316-56. 
erased. ${ }^{15}$ The nature of Johannes Brunet's relationship with the French royal court is not clear. As Jeffrey Dean has noted, the unicum Hellas madame que i'ayme (fols. LXXIX ${ }^{\mathrm{v}}$ iiii $^{X X I r}$ ) is squarely in the style of Févin’s three-part arrangements, which suggested to him that it may have been the work of a close contemporary of Févin named Johannes Brunet, who was a Benedictine priest from Brittany of noble family. This Brunet was a member of the papal household in Rome from 1486 until 1493 and served as organist of San Pietro in Rome in 1490-1, meanwhile becoming the abbot of the monastery of St Mathieu-deFinistère in Brittany, where he died on 6 June $1515 .{ }^{16}$ Nothing certain is known about the musician named Johannes Boytel who wrote the fragmentary canonic motet that opens MS 1760, unless he can be identified with Maître Jean Boitel, a vicar in the cathedral of Tours, who received a surplice from a bequest made by a canon of the church on 8 November 1503. ${ }^{17}$ Of the fifty-seven compositions in MS 1760, Jacob Obrecht's motet Parce Domine

15 On the authorship of J'ayme bien mon amy, see L. Litterick, 'Who Wrote Ninot’s Chansons?', in R. Sherr (ed.), Papal Music and Musicians in Late Medieval and Renaissance Rome (Oxford and Washington, 1998), pp. 240-69; and the Grove Music Online article on Ninot le Petit by D.

Fallows and J. Dean. The chanson was not included in the Ninot le Petit opera omnia edition of Barton Hudson (Ninot le Petit: Collected Works, ed. B. Hudson (Corpus Mensurabilis Musicae, 87; n.p., 1979). My most sincere thanks go to Dr Julia Craig-McFeely, the Director and Project Manager of the Digital Image Archive of Medieval Music (DIAMM), who provided me with ultraviolet photographs of this and numerous other folios in MS 1760.

16 Brunet's biography was first explored in detail in C. Reynolds, 'Musical Careers, Ecclesiastical Benefices, and the Example of Johannes Brunet', Journal of the American Musicological Society, 37 (1984), 49-97. The biography and musical output of the composer named Johannes Brunet were re-evaluated in J. Dean, 'Johannes Brunet and Nato canunt omnia', Revista de musicología, 16, no. 5, del XV Congreso de la Sociedad Internacional de Musicología: Culturas Musicales del Mediterráneo y sus Ramificaciones, 5 (1993), pp. 2656-72.

17 The orthography of Boytel's name in the tabula of MS 1760 requires comment, since the downward extender has been omitted from the ' $y$ '. A trace of the missing extender is clearly visible from an ultraviolet photograph of the tabula. For a similar ' $y$ ' in the tabula without a downward extender see the orthography of On a mal dit de mon amy on fol. $3^{\mathrm{r}}$. Concerning the Jean Boitel who was a vicar of Tours, see Tours, Archives Départementales, 37, Cote: G/1023 (www.bvh.univ-tours.fr/Minutes/resrecherche.asp?motclef=lad\&offset=120). The name Jean Boitel was not uncommon during the first half of the sixteenth century. An individual named Jean Boitel wrote Coustumes generalles du bailliage d'Amiens avec celles des prevostez de Monstroeul, Beauquesne, Foullois, Saint Riquier, Doullens et Beauvoisis nouvellement publiées (Paris, 1516). This Jean Boitel was a greffier in the bailliage of Amiens in 1507. See Manuscrits de Pagès, marchand d'Amiens, écrits à la fin du $17^{e}$ et au commencencement du $18^{e}$ siècle sur Amiens et la Picardie, i, ed. L. Douchet (Amiens, 1856), p. 477. Another Johannes Boytel served as a perpetual vicar at the altar of the Holy Cross and Saints Philip and James Apostles in the church of Saint Mary the Virgin in Prempfzlow, Pomerania, in 1493 (R. Klempin, Diplomatische Beiträge zur Geschichte Pommerns aus der Zeit Bogislafs $X$ (Berlin, 1859), pp. 91, 182). Finally, in 1541 a 'Jean Boitel' prepared a compte of 'cens et rentes' due to the Abbey of St-Éloi of Noyon for the abbé commendataire, the Cardinal de Tournon, who also was serving as the maitre de chapelle for the French royal chapel at that time (Inventaire sommaire des Archives 
populo tuo is the only work that might seem out of place in a manuscript containing the musical repertory of the French royal court. But even if it is not clear how Obrecht's motet entered into the court's musical repertory, there is reason to suppose that it did circulate alongside court music during the early decades of the sixteenth century, since it appears in four of the eight music manuscripts that provide the greatest number of concordances with MS 1760, CopKB 1848 (Lyon, c. 1520), LonBL 35087 (Bruges, 1505-6), SGallS 463 (Glarus, c. 1540) and UppsU 76a (Lyon? c. 1498-1505, with later additions). ${ }^{18}$

\section{THE DECORATION OF MS 1760}

Scholarly analysis of the decoration of MS 1760 corroborates French court provenance. In an unpublished paper offered at the 1970 national meeting of the American Musicological Society in Toronto Herbert Kellman noted that some of the continuation signs used in MS 1760 resemble an ermine tail, the principal heraldic device of the duchy of Brittany from the thirteenth through to the sixteenth centuries, which also appears on the arms used by Anne of Brittany, queen of France from 1491 until her death 9 January $1514 .{ }^{19}$ The first detailed

Departementales antérieures à 1790, Oise, Archives ecclésiastiques, série H, ii, ed. E. Roussel (Beauvais, 1897), p. 142).

18 The other four manuscripts are FlorBN Magl. 117, LonBLH 5242, FlorBN II.I.232 and FlorL 666. The latter two manuscripts appear on this list because they contain all five motets in Josquin's $O$ admirabile commercium cycle. Concerning the dating and provenance of the manuscript sources mentioned here and in the Appendix, see the literature cited in the Census-Catalogue and also P. W. Christoffersen, French Music in the Early Sixteenth Century: Studies in the Music Collection of a Copyist of Lyons; The Manuscript 'Ny kgl. Samling $18482^{\circ}$ in the Royal Library, Copenhagen (Copenhagen, 1994); Cristoffersen, 'The Uppsala Chansonnier MS 76a: Dating and Function’ (http://uppsala.pwch.dk/Dating.html); I. Kraft, Einstimmigkeit um 1500: Der Chansonnier Paris, BnF f. fr. 12744 (Beihefte zum Archiv für Musikwissenschaft, 64; Wiesbaden, 2009), p. 69; and Joshua Rifkin's review of Kraft's work in Speculum, 86 (2011), pp. 516-18. Obrecht's motet may have entered into French circulation during the final decade of the fifteenth century, to judge from an archival record from Antwerp discovered by Eugeen Schreurs revealing that Obrecht made an extended visit to France in 1492-3. See R. C. Wegman, Born for the Muses: The Life and Masses of Jacob Obrecht (Oxford, 1994), p. 310, n. 54.

19 Kellman, 'Musical Links between France and the Empire, 1500-1530', paper read at the Annual Meeting of the American Musicological Society, Toronto, Canada, 1970. The precise significance of the ermine tail continuation signs has been questioned by Louise Litterick, who argued that their use in MS 1760 'cannot be considered more than incidental' since ermine tails constitute a distinct minority of such signs in the manuscript (Litterick, 'The Manuscript Royal 20.A.XVI of the British Library' (Ph.D. diss., New York University, 1976), p. 50, n. 30). That the whole and half ermine tails in MS 1760 were not merely decorative, however, is suggested by the fact that they are the only continuation signs in the manuscript that employ imagery used in contemporaneous heraldry. The following seven continuation signs appear in MS 1760: three-

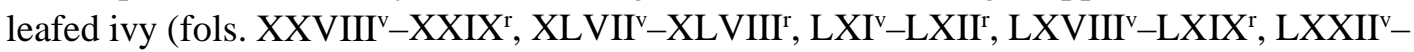

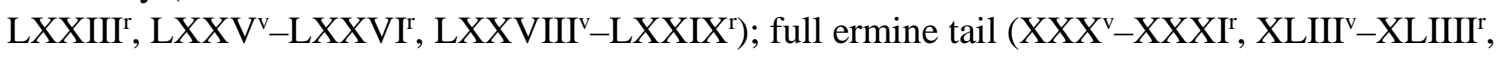

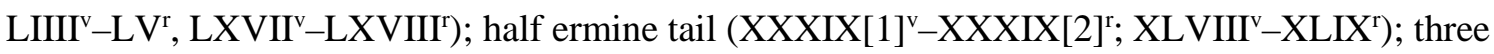


analysis of the manuscript's illuminations was published in 1976 by Louise Litterick, who pointed out that the decorative borders of fols. $\mathrm{I}^{\mathrm{V}}$ and $\mathrm{II}^{\mathrm{r}}$ and the majuscules throughout the manuscript closely resemble the work of the French court painter Jean Bourdichon (14571521), and in particular his Grandes heures d'Anne de Bretagne (Paris, Bibliothèque nationale de France, lat. 9474). ${ }^{20}$

The accuracy of Litterick's observations may be confirmed through comparison of the two decorated borders of MS 1760, fols. $\mathrm{I}^{\mathrm{V}}$ and $\mathrm{II}^{\mathrm{r}}$, with similar borders appearing in the Grandes heures d'Anne de Bretagne and a single decorated border in another book containing Bourdichon's art, the Hours of Mary of England (Lyon, Bibliothèque municipale, MS 1558), which was owned by Anne's successor as Queen of France, King Henry VIII's younger sister Mary Tudor (r. 5 November 1514-Jan. 1515; see Figure 1). ${ }^{21}$ The Grandes heures, which was prepared by Bourdichon between 1503 and $1508,{ }^{22}$ is one of the major works of art from the court of Louis XII, and its 238 folios present a wide variety of paintings based on religious or botanical subjects. The folio from Anne's hours shown in Figure 1a depicts roses ('Rosa rubea'), lilies ('Lilium’), butterflies, a ladybird and other fauna found in the fields around Tours, where Bourdichon and members of the School of Tours worked during the late fifteenth and early sixteenth centuries. These are very similar to the roses, lilies, butterfly and ladybird appearing on fol. $\mathrm{I}^{\mathrm{v}}$ of MS 1760, and dragonflies, strawberry plants, forget-me-nots, hazelnut and chickpea flowers closely resembling those on fol. II ${ }^{\mathrm{r}}$ of Pepys 1760 may be found scattered throughout Anne's book. ${ }^{23}$ Fol. $8^{\mathrm{r}}$ of Mary's book contains similar paintings of a rose, lilies, two varieties of forget-me-nots, strawberries, a chickpea flower, and a dragonfly, butterflies and a ladybird. ${ }^{24}$ The motif of rose and lily

dots $\left(\mathrm{XL}^{\mathrm{v}}-\mathrm{XLI} \mathrm{I}^{\mathrm{r}}\right)$; cross $\left(\mathrm{LI}^{\mathrm{v}}-\mathrm{LII}{ }^{\mathrm{r}}\right)$, three white rectangles $\left(\mathrm{LII}-\mathrm{LIII}{ }^{\mathrm{r}}\right)$; and aix $\left(\mathrm{LXXVII}{ }^{\mathrm{v}}-\right.$ LXXVIII $)$.

${ }^{20}$ Litterick, 'The Manuscript Royal 20.A.XVI', pp. 46-57. For an introduction to Bourdichon's biography and works, see D. Mac Gibbon, Jean Bourdichon: A Court Painter of the Fifteenth Century (Glasgow, 1933). Concerning MS Latin 9474, see J. P. Harthan, Books of Hours: With Historical Survey and Commentary (London [c1977], repr. New York, [1982]), pp. 128-33. Paris, Bibliothèque nationale de France (hereafter $\mathrm{BnF}$ ), lat. 9474 has been published online by the Bibliothèque nationale de France at http://gallica.bnf.fr/ark:/12148/btv1b52500984v/f1.item, and is published here by permission.

21 The image is taken from http://bvmm.irht.cnrs.fr/consult/consult.php?VUE_ID=1333077, and is published here by permission of the Bibliothèque municipale de Lyon.

22 Harthan, Books of Hours, p. 128.

23 The following folios in Anne's book depict plants painted on fol. II $^{\mathrm{r}}$ of MS 1760: fol. 27v , forgetme-nots; fol. $34^{\mathrm{r}}$, hazelnut; fol. $48^{\mathrm{r}}$, chickpea; fol. $54^{\mathrm{r}}$, strawberry plant. Two dragonflies appear on fol. $34^{\mathrm{r}}$ along with the hazelnut.

24 The two varieties of forget-me-nots, 'Ne me obliez mie' and 'Souviens vous de moy', may be found on fols. $27^{\mathrm{v}}$ and $29^{\mathrm{v}}$ in the Grandes heures". Fol. $8^{\mathrm{r}}$ of Mary's book also has a starflower and 
dominates fol. $\mathrm{I}^{\mathrm{v}}$ in MS 1760 and even appears within the illuminated initial that begins Gascongne’s motet Ista est speciosa.

The close correspondence between the imagery used on the two decorated borders of Pepys 1760 and the single decorated border of MS 1558 is particularly suggestive because of the known history of Mary’s book. According to the art historian Roger Wieck, MS 1558 was initially prepared by the royal court painter Jean Poyet (fl. Tours, 1483-1503) between 1495 and 1500 for an anonymous owner, but in 1514 additional folios were added by Bourdichon and an unknown court painter employed by Claude de France (1499-1524), daughter of Anne of Brittany and later wife of King Francis I. That the decorative border on fol. $8^{\mathrm{r}}$ was one of the additions in 1514 is strongly suggested by the fact that it is the only folio in the manuscript containing this type of floral art and is in an artistic style markedly different from any other folio. Wieck describes the reason for the 1514 alterations as follows:

$<$ EXT $>$ Inscriptions within the manuscript indicate that it had been given by Louis XII after the death of Anne de Bretagne, the king's second wife, to Mary Tudor of England, his third wife. The manuscript had apparently been picked up by Louis secondhand as a ready gift for his new wife. Returning to England after the quick death of her spouse, Mary then gave the book again, as an inscription tells us, to her brother the king, Henry VIII. The fact that the later remodeling, which must have been around the time the manuscript became a bridal gift, was executed by artists other than Poyet might be significant. ${ }^{25}</$ EXT $>$

The redecoration of Mary's book in the autumn of 1514, when England and France temporarily ceased their warfare to celebrate the marriage of Henry's VIII's younger sister to the king of France, suggests that the choice of lilies and roses for the border of fol. $8^{\mathrm{r}}$ of MS 1558 may not have been accidental, since in the early sixteenth century these flowers were strongly associated with French royalty and the House of Tudor respectively.

ENGLISH OWNERSHIP OF MS 1760

\footnotetext{
a daisy at the bottom of the page, which appear in the Grandes heures on fols. $18^{\mathrm{r}}$ and $44^{\mathrm{v}}$, respectively. The majuscules on fols. $31^{\mathrm{v}}, 43^{\mathrm{r}}, 52^{\mathrm{r}}, 54^{\mathrm{v}}, 64^{\mathrm{r}}, 82^{\mathrm{v}}$ and $93^{\mathrm{r}}$ of Mary's book look like Bourdichon's work. This manuscript is discussed in R. S. Wieck, 'The Artist Jean Poyet and his Oeuvre', in The Hours of Henry VIII: A Renaissance Masterpiece by Jean Poyet, ed. R. Wieck, W. M. Voelkle, and K. M. Hearne (New York, 2000), pp. 26-7. It is published in Bibliothèque virtuelle des manuscrits médiévaux (http://bvmm.irht.cnrs.fr/consult/consult.php?COMPOSITION_ID=7232\&corpus=decor\&page=).

25 Wieck, 'The Artist Jean Poyet', pp. 26-7. The two inscriptions are on fols. 36r and 95r.
} 
Although the repertory of MS 1760 and the illuminations on fols. $\mathrm{I}^{\mathrm{v}}$ and $\mathrm{II}^{\mathrm{r}}$ leave little doubt that the Pepys manuscript was created at the French royal court, other aspects of its decoration indicate that it became the property of the English royal court prior to 1528. Pepys titled the volume 'K. Hen. 7 [King Henry VII]/ Musick' in gold lettering on the new leather half-spine he added to the original cloth-of-gold covers. Moreover, the opening illuminated folios contain two shields bearing the Cross of St George (red cross on a white shield; see Figure1b), heraldry that formed an integral part of the hoists and standards used by the English kings from the Middle Ages through the sixteenth century. That the manuscript had entered the English royal library by not later than 1528 is suggested by two pieces of evidence. In the upper right corner of the opening flyleaf appears the shelf number 'No. 1281', a number that has been crossed out with red ink (see Figure 2). As Ian Woodfield first noted, during the sixteenth century this number was a shelfmark used by the English royal library at Westminster Palace. ${ }^{26}$ More recently the historian James P. Carley has confirmed that MS 1760 probably was a part of the Westminster Palace library collection in $1542 .{ }^{27}$ The fact that the same shelf number, written by the same or a similar scribal hand, also appears in a roughly contemporaneous music manuscript produced by the French royal court but currently a part of the Royal Collection of the British Library, LonBLR 20 A. xvi, led Woodfield, Carley and other scholars to conclude that during the sixteenth century the two manuscripts were shelved side by side in the Westminster Palace library. ${ }^{28}$ A terminus

26 Woodfield marshalled much of the evidence linking MS 1760 to the English royal court in his 1973 MMus dissertation 'The Pepys Manuscript 1760: A Critical Study of the Manuscript and its Origins, and a Transcription on the Works of Matthieu Gascogne Contained Therein' (MMus, University of London, King's College, 1973). I am indebted to Prof. Woodfield for generously sending me a copy of his master's document, which sparked my own thinking about the history of the manuscript after its arrival at the English court. Since my copy of his study does not have pagination, I have added my own page numbers when referring to this source. The opening flyleaves of MS 1760 provide three early crossed-out shelf numbers for the manuscript, 'No. 1281' (1542 Westminster Palace Library number), '973B' (original Pepys number) and '1065' (1693 Pepys catalogue number). Although the original 1693 catalogue is no longer extant, that 1065 was the 1693 number is indicated by Pepys's 1700 catalogue, the catalogue Supellex Literaria Samuelis Pepys, which provides both 1693 and 1700 numbers. See the facsimile edition of the 1700 catalogue in Catalogue of the Pepys Collection, vii, pts. 1-2. MS 1760 references occur on pp. 89 and 161 of pt. 1 and pt. 2, p. 177.

27 Henry VIII's libraries have been comprehensively catalogued and evaluated in several works written by J. P. Carley, including The Libraries of King Henry VIII (London, 2000) and The Books of King Henry VIII and his Wives (London, 2004). The 1542 library inventory is described and the contents of the Westminster Library are catalogued in The Libraries, pp. 30-226. Carley describes Pepys 1760 as a part of Henry’s library in The Books of King Henry VIII, pp. 21-2.

28 Woodfield. 'The Pepys Manuscript', pp. [24]-[25]. Carley, The Libraries, p. 213. MS 1760 and LonBLR 20 A. xvi are listed on p. 213 of Carley's catalogue. Carley suggests that these manuscripts correspond to 'No. 37' of the 1542 inventory, 'A pricke songe booke of masses and 
ante quem of 1528 for the acquisition of MS 1760 by the English royal court is provided by the royal heraldry appearing at the head of the tabula on fol. $2^{\mathrm{v}}$ of the opening section (see Figure 3). English royal heraldry employing the red dragon of Cadwallader as a dexter supporter and the white greyhound of the Nevills as a sinister supporter, surrounding the symbol of the Order of the Garter and royal arms over green and white Tudor livery, is primarily associated with King Henry VII (r. 1485-1509), but as Lawrence F. Bernstein pointed out in 1973, his son Henry VIII also used this heraldry from his coronation as king of England in 1509 through to 1528, evidence extending the possible range of dates for the incorporation of MS 1760 into the English royal library almost two decades into the younger Henry’s reign. ${ }^{29}$

Attempts to determine which English ruler inspired this heraldry are complicated by the existence of a now-missing portrait that once graced fol. I ${ }^{\mathrm{v}}$ of MS 1760. An expanded version of the information provided by Samuel Pepys on the spine of MS 1760 was published in 1697 by the Oxford scholar Edward Bernard in his Catalogi librorum manuscriptorum Anglie et Hibernie. On page 208 of this catalogue appears the following description of MS 1760: ‘6806. 87. Vocal Musick (of different Styles) compos’d by the most Eminent Masters, English and Forrein, in the time of King Hen. VII. for the then Prince of Wales; being the Prince’s Original Book, elegantly prickt and illuminated with his Figure in Miniature. Pergam. ${ }^{30}$ This is the earliest source to mention that MS 1760 once contained a portrait of a member of the English royal family, seemingly one of King Henry VII's two sons, Prince Arthur (d. 1502) or his younger brother, Henry (1491-1547), who was Prince of Wales from 1502 until his accession to the royal throne in 1509. To judge from the rough

anthemes' (Carley, The Libraries, pp. 38 and 213). For a photograph of a very similar shelf number from the Westminster library c. 1548, see J. P. Carley, 'The Royal Library under Henry VIII', ch. 13 of L. Hellinga and J. B. Trapp (eds.), The Cambridge History of the Book in Britain (Cambridge, 1999), p. 276. Photographs of other royal manuscripts containing old royal library shelf numbers from the 1540s or earlier may be found in British Library, Digitised Manuscripts (www.bl.uk/manuscripts/). See, for example, Royal MS 20 B. xx, 'no. 475'; Royal MS 19 B. xv, 'no. 22'; Royal MS 19 C. iv, 'no. 437'; Royal MS 16 C. ix, 'no. 1414'; and Royal MS 20 A. ii, 'no. 1046'.

29 Bernstein, 'La Courone et fleur', p. 8, n. 31. Bernstein drew his information concerning Henry VIII's heraldry from C. Davenport, English Heraldic Book Stamps (London, 1909), p. 220. The heraldry in MS 1760 must refer to a king and not a Prince of Wales, since Henry VIII's arms while he was Prince of Wales (1502-9) included a label of three points argent over quarterly France and England. See J. H. and R. V. Pinches, The Royal Heraldry of England (London, 1974), p. 139. Lowinsky was the first to observe that the arms must be those of the king and not the Prince of Wales ('A Music Book for Anne Boleyn', pp. 162-4).

30 In Bernard's entry 6806 is his catalogue number for the Pepys Library and 87 is his number for MS 1760. 
excision of a rectangle of parchment on fol. $\mathrm{I}^{\mathrm{v}}$ of the main body of MS 1760, this portrait was located right above the single notated part for Gascongne's twelve-voice canonic motet Ista est speciosa (see Figure 1b). Its excision also removed from fol. $\mathrm{I}^{\mathrm{r}}$ virtually all of Boytel's canonic motet Ave Maria and the first stave of Févin's canonic motet Quae est ista quae ascendit. The information in Bernard's catalogue appears to have come directly from Pepys, since the latter's correspondence indicates that in the autumn of 1694 he sent duplicate listings of the manuscripts in his library to two scholars intimately involved in the compilation of the Catalogi librorum manuscriptorum, Edmund Gibson and Arthur Charlett. $^{31}$

Woodfield's researches suggest that the now-missing portrait may still have been in place as late as 1779, when the music historian Charles Burney travelled to Cambridge in search of new material for the second volume of his history of music. Correspondence between Burney and his friend the Revd Thomas Twining indicates that he made the trip in September 1779 to look for new early music manuscripts, and that after the trip he sent Twining the canonic inscription appearing above Gascongne's twelve-voice canon, 'Epithoniza bina tempora pausando vel econverso', whose translation baffled Twining. Twining was not alone in his confusion, for he noted that Burney had told him that 'the music, you say, is as unintelligible as the title'. ${ }^{32}$ Burney subsequently demonstrated close familiarity with MS 1760 through several detailed references to its content in his General History of Music (1782-9), which not only are much more accurate than Pepys's description as given in the Bernard catalogue, but also unequivocally identify the manuscript as the property of Prince Henry prior to his accession to the English royal throne in $1509 .{ }^{33}$

${ }^{31}$ Pepys's relationship with the compilers of Bernard's catalogue and some of the correspondence concerning his contribution are discussed in The Catalogue of the Pepys Library at Magdalene College Cambridge, v: Manuscripts, pt. 1: Medieval, compiled by R. McKitterick and R. Beadle (Cambridge, 1992), p. xi; see also vii, pt. 1, p. xxvi. Other letters of Pepys to friends from 1694 concerning the catalogue appear in Letters and the Second Diary of Samuel Pepys, ed. R. G. Howarth (London, Toronto and New York, 1933), pp. 244-51. Concerning the biographies of Gibson, Bernard and Charlett, see the Oxford Dictionary of National Biography (ODNB; www.oxforddnb.com).

32 Woodfield, 'The Pepys Manuscript', pp. [37]-[40].

33 Ibid. The originals quoted by Woodfield may be viewed in Burney, A General History of Music, bk. 2 (1782) (http://javanese.IMSLP.info/files/imglnks/usimg/5/55/IMSLP72267-PMLP144843Burney.pdf): 'In the music book of Prince Henry afterwards Henry VIII., which is preserved in the Pepys collection at Cambridge, there are several of his [Josquin’s] compositions' (p. 738); ibid., 'About the first year of Henry the Sixth, 1422, French and English seem pretty equally balanced, and to have been used indifferently; however, very little improvement was made in our language and versification from the time of Edward the Fourth, to that of Henry the Eighth. Indeed, few English songs are to be found, which were set to original music during that period; it 
Whether he had seen the miniature portrait himself, or had talked with librarians who had seen it, Burney clearly did not share the uncertainties of modern scholars, who have debated whether the missing portrait portrayed Prince Arthur or Prince Henry. ${ }^{34}$

The spine inscription, the English royal arms above the tabula, the missing miniature of Henry VIII, the St George shields and Burney’s observations are not the only evidence linking MS 1760 to the English royal court, since there are several inscriptions on the pastedown pages at the beginning and end of the manuscript that document its continued presence in England into the 1540s and beyond. The opening paste-down provides two inscriptions that are written upside down (see Figure 2). The first is in the numeric/letter code '1 13.13.5.18.19.1.13.8.14.15. $\therefore$ 9.18.12.9.8.14.15.5. $\therefore$ ', which scholars have long recognised may be translated as 'Anne Stanhop $\therefore$ is mi hope $\therefore$ '. Just underneath the code appears what may be a date, '1.1.53', written in a different colour of ink, and under these numbers is written the following anathema against anyone who might attempt to steal the book: 'He that stelle thys boke a shalle be / hangked up on a hoke nouther be watter nor / be lond bot wyt a fayer hempyng bond.' On the back paste-down one may faintly discern 'For my lade anne', followed by a cancelled word, now indistinguishable. Anne Stanhope Seymour (c. 1510-87) was the second wife of Edward Seymour (c. 1500-52), Lord Protector of England after Henry VIII's death and the brother of Queen Jane Seymour. ${ }^{35}$ Anne was a

having been the fashion for the great to sing none but French words, as appears by the Music Book of Prince Henry, son of Henry the Seventh, in which all the songs are in French, Italian, or Latin' (p. 784). A third citation of MS 1760 appears in the next volume of Burney's history, which was published in 1789: 'John Richefort, or Ricciafort, is placed by Walther in the middle of the sixteenth century; but he was certainly a composer many years before that period, as we find his name not only in the second book of the Motetti de la Corona . . . but to a motet in a musicbook, preserved at Cambridge, of Henry VIII, when prince of Wales’. Burney, A General History of Music, from the Earliest Ages to the Present Period (1789), critical notes by Frank Mercer (New York, 1935), ii, p. 246.

34 The following scholars have argued that MS 1760 was compiled for Arthur, Prince of Wales prior to his death in 1502: A. T. Merritt, 'A Chanson Sequence by Fevin', in Essays on Music in Honor of Archibald Thompson Davison by his Associates (Cambridge, Mass., 1957), pp. 91-9; J. R.

Braithwaite, 'The Introduction of Franco-Netherlandish Manuscripts to Early Tudor England: The Motet Repertory’ (Ph.D. diss., Boston University, 1967) , i, pp. 54-5; ii, passim; v, pp. 79-200; and S. R. Charles, 'Hillary-Hyllayre: How Many Composers?', Music \& Letters, 55 (1974), pp. 61-9.

35 Concerning Anne Stanhope Seymour, see S. Alford, Kingship and Politics in the Reign of Edward VI (Cambridge, 2002); A. F. Pollard, England under Protector Somerset: An Essay (London, 1900; repr. New York, 1966), pp. 16, 92, 112n., 182, 285n., 289, 319n.; and C. Armbruster, 'A Woman for Many Imperfections Intolerable: Anne Stanhope, the Seymour Family, and the Tudor Court' (Master's thesis, Louisiana State University, 2013) (http://etd.lsu.edu/docs/available/etd11072013-100517/unrestricted/armbruster_thesis.pdf). 
literary patron and the beneficiary of more literary dedications than any other woman in early Tudor England. Both Anne and her husband were arrested and charged with treason and felony in 1551, charges that led to the execution of Edward Seymour on 22 January 1552. Anne remained incarcerated until she was freed by Queen Mary in August 1553. Woodfield and other scholars have noted that these inscriptions suggest that Anne Stanhope Seymour once owned MS 1760. That she possessed it up until the time of her death in 1587 is suggested by a will she created in July 1586 in which she left the following bequest to Honora Rogers, daughter of Sir Richard Rogers of Bryanstone, Dorset and the wife of her grandson Edward Seymour, Viscount Beauchamp (1561-1612): 'Item, I geve to my sonne Beuchampes wife a booke of gould kept in a grene purse, and a payer of bracelets without stones. 36

\section{OVERPAINTING AND ERASURES IN THE MS}

Signs of overpainting and erasure in the manuscript add another layer of complexity to attempts to determine the original purpose for which it was created. As Louise Litterick first noted, ${ }^{37}$ the St George crosses on fols. $\mathrm{I}^{\mathrm{r}}$ and $\mathrm{II}^{\mathrm{r}}$ were painted over slightly larger shields surmounted by trifoliated crosses that had dark backgrounds and white crosses. The original dark shields are clearly visible on the verso side of these folios because of paint bleedthrough (see Figure 4a). ${ }^{38}$ Litterick proposed that the original shields were red with white crosses, heraldry associated with the military order of the French nobility during the fifteenth and sixteenth centuries, the Order of St Michael. Figure 4b shows the device on a French flag at the Battle of the Spurs in a painting from 1513; similar colours and design appear on a depiction of a shield held by Saint Michael in Jean Fouquet's well-known painting of the founding of the Order of Saint Michael by King Louis XI (r. 1461-83), in which the white cross outlines a smaller blue cross. ${ }^{39}$ Ultraviolet photography reveals that a white cross that might have been intended for a third shield of Saint Michael once graced the bottom of the

36 The will is transcribed in S. Higginbotham, 'The Last Will of Anne Stanhope, Duchess of Somerset', www.susanhigginbotham.com/blog/posts/the-last-will-of-anne-stanhope-duchess-ofsomerset/. On Honora Rogers and Edward Seymour, Viscount Beauchamp, see the Oxford Dictionary of National Biography, s.v. 'Edward Seymour' (www.oxforddnb.com).

37 Much of the evidence presented in this paragraph has been drawn from Litterick, 'The Manuscript Royal 20.A.XVI', pp. 46-57.

38 Figure 4b is taken from www.royalcollection.org.uk/collection/406784/the-battle-of-the-spurs. Detail from Anon., Flemish School (c. 1513), the British Royal Collection. Royal Collection Trust / (C) her Majesty the Queen Elizabeth II 2016. Figure 4c is taken from https://en.wikipedia.org/wiki/Order_of_Saint_Michael\#/media/File:Louis_XI_pr\%C3\%A9side_le _chapitre_de_Saint-Michel.jpg. Original Paris, BnF f. fr. 19819, fol. 1.

39 See Paris, BN MS f.fr. 19819, fol. $1^{\mathrm{r}}$ (http://gallica.bnf.fr/ark:/12148/btv1b8427226q/f9.image). 
folio immediately prior to fol. $\mathrm{I}^{\mathrm{r}}$ in MS 1760, although it now is erased (see Figure 5a). It also reveals that several lines of what appears to be French writing have been erased from the top of the first flyleaf (Figure 5b), and that the English royal coat of arms was painted over what appears to have been the beginning of the Latin inscription 'In laudem celestis regine' written in red ink below the tabula on fol. $2^{\mathrm{v}}$ (Figure $5 \mathrm{c}$ ). ${ }^{40}$ This evidence of overpainting and erasure suggested to Litterick that

$<$ EXT $>$ while an English king or Prince of Wales was clearly the ultimate recipient of this manuscript, he was not the one for whom it was originally intended ... Both the ermine tails and the Crosses of Saint-Michel, if such they are, confirm the strong indication of French court origin already provided by the decoration of the manuscript and suggest further that the volume may have been originally intended for Louis XII himself, or for the royal couple [Louis XII and Anne of Brittany]. ${ }^{41}</$ EXT $>$

Errors in the English royal heraldry appearing above the tabula of MS 1760 suggested to Litterick that the manuscript was redecorated in France and not England (see Figure 3). Building upon earlier analysis presented by Kellman and Bernstein, she pointed out the following errors in the Pepys coat of arms: (1) the rim of the crown is decorated solely with trefoils, without alternating fleurs-de-lis and crosses-pattée; and (2) the garter is white instead of blue and does not have its requisite looped end. She also noted that crowns decorated with nothing but trefoils 'are not uncommon in French paintings and manuscripts of this period'. On this basis she suggested 'these inaccuracies would seem to indicate that the heraldry was entered into the manuscript some place other than England' ${ }^{42}$ Although this hypothesis may well be correct, the inaccuracies in the royal heraldry also might have

40 The only way to see the overpainted portion of the inscription on fol. $2^{\mathrm{v}}$ is to look at the back side of the tabula folio (fol. 2r) under ultraviolet light, as appears in Figure 5(c). The image has been flipped so that the overpainted text can be read as if one were reading it from fol. $2^{\mathrm{v}}$. Most of the overpainted text is illegible, but a word that might be 'Celestis' appears underneath the red dragon, and what may be 'egregie' is visible under the right side of the garter on the same line. Ian Woodfield was the first to employ ultraviolet photography to examine the overpainting and erasures in MS 1760.

${ }^{41}$ Litterick, 'The Manuscript Royal 20.A.XVI', pp. 48, 51.

42 Ibid., p. 48. For a roughly contemporaneous depiction of the royal arms that is more accurate than the Pepys MS but still presents errors in the royal crown see the opening folio of LonBLR 8 G. vii, a music manuscript created in the workshop of Petrus Alamire in Mechelen at the behest of Margaret of Austria that probably was presented to Henry VIII and his first wife, Catherine of Aragon, between 1513 and 1525. See the Census-Catalogue entry and also British Library, Catalogue of Illuminated Manuscripts, Royal 8 G. vii (www.bl.uk/catalogues/illuminatedmanuscripts/record.asp?MSID=6516\&CollID=16\&NStart=80 707). 
stemmed from other factors, since there are Continental manuscripts from about the same time that accurately depict the details of Henry VII’s heraldry. For example, British Library, Royal MS 17 F. v, a history of Godefroy, Duc de Bouillon and King of Jerusalem, that was created in Bruges by the Master of the Dresden Prayer Book during the last quarter of the fifteenth century, provides an almost textbook example of Henry VII's arms on fol. $3{ }^{43}$

Thanks to the painstaking research on MS 1760 conducted by Litterick, Woodfield, Kellman, Lowinsky, Bernstein, Fenlon and others, there now is a measure of scholarly consensus concerning the early history of MS 1760. It is widely accepted that the manuscript originally was created in France sometime during the early sixteenth century, probably at the royal court of Louis XII. Prior to 1528 it was modified to make it a suitable gift for either Henry VII or one of his two sons, Arthur or Henry VIII. At the time of this change in ownership, its two Crosses of Saint Michael were overpainted with the English national emblem of Saint George and a version of the royal coat of arms used by both Henrys was added above the tabula. Probably these changes were made in France and not England, since the royal arms are defective in several details. Finally, Burney's testimony that MS 1760 was the personal property of Henry VIII greatly strengthens the position of scholars who have argued that the central decoration of MS 1760, the missing miniature on fol. I ${ }^{\mathrm{v}}$, depicted Henry VII's second son and not his older brother Arthur. Burney's evidence (which is in keeping with Henry VIII's passionate love of music) reduces the time span within which the manuscript was obtained by the English royal court to the period 1502-28. This may be limited even further, if one will grant that the presence of arms used by Henry VIII after his accession to the royal throne, and not the arms he used as Prince of Wales, provides very strong evidence that MS 1760 came into his possession in 1509 or later, notwithstanding Bernard's and Burney's identification of the missing miniature as a 'Prince of Wales'. We shall return to this point later in this essay.

Over the past fifty years there have been a number of attempts to further specify the purpose or purposes that led to the creation and modification of MS 1760. Lowinsky suggested that it might have been 'written for' Henry VIII in 1516 to celebrate the birth of

43 See British Library, Catalogue of Illuminated Manuscripts, Royal 17 F. v (www.bl.uk/catalogues/illuminatedmanuscripts/record.asp?MSID=7687\&CollID=16\&NStart=17 0605). This heraldry obviously does not include the dragon and greyhound supporters, but it does have the looped Garter and the alternating fleurs-de-lis/crosses-pattée. The dragon and hound figures are often omitted from heraldry on Henry VII's and Henry VIII's manuscripts in the Royal Collection of the British Library. 
his daughter Mary. ${ }^{44}$ Bernstein proposed that it probably was compiled for Henry VIII $c$. 1509-16, but he was not willing to entirely rule out the possibility that it was created for him prior to his accession to the royal throne in $1509 .{ }^{45}$ As noted previously, Louise Litterick argued that the manuscript originally was 'intended' for Louis XII, or possibly Louis and Anne of Brittany, but then was redirected to England. ${ }^{46}$ She proposed the coronation of Henry VIII in June 1509 as a likely occasion for such a gift, a conclusion echoed by Iain Fenlon in 1982. ${ }^{47}$ In 2006-7 I argued in several conference papers that MS 1760 was created as a wedding gift from the French royal court to Mary Tudor in late 1514. The same argument was made independently by Frank Dobbins at a MedRen conference in Cambridge in the summer of 2006. ${ }^{48}$ Finally, in 2009 Alexander Robinson adopted the argument that MS 1760 was given as a gift to Mary Tudor in 1514, but modified it by arguing that repertorial evidence within the manuscript indicated that it originally had been prepared for Louis XII around 1512. ${ }^{49}$ Each of these hypotheses will be evaluated in due course. But first we will consider new evidence drawn from the manuscript's organisation, structure, decoration and content.

\section{THE ORGANIZATION AND STRUCTURE OF MS 1760}

One may deduce from the organisation and structure of MS 1760 that that the manuscript was created over a limited period of time by a small group of musicians and artisans who

44 Lowinsky, 'A Music Book for Anne Boleyn', pp. 162-4.

45 Bernstein, 'La Courone et fleur', pp. 8, 13.

46 Litterick, 'The Manuscript Royal 20.A.XVI', pp. 46-57.

47 Fenlon, Cambridge Music Manuscripts, p. 125.

48 Brobeck, 'A Missing Portrait and Mathieu Gascongne's Canonic Motet Ista est speciosa: New Evidence for a Reinterpretation of the Origins of Pepys MS 1760', paper read at the Annual Meeting of the American Musicological Society, Québec, Canada, 2007. Also presented at the Annual Meeting of the Central Renaissance Conference, San Antonio, Tex. (2007) and the Annual Meeting of the Rocky Mountain Chapter of the American Musicological Society, University of Denver (Apr. 2006). Frank Dobbins outlined his theory of the manuscript to me in an email dated 20 Apr. 2007: 'My ideas on Pepys 1760 were outlined in MedRen 2006 at Cambridge in context of an edition of Harley 5242 which I have prepared for RRMR. Basically they revolve around the illumination and repertoire which suggest that the ms was compiled at Blois for Louis XII, who offers it as wedding gift to Mary Tudor, who brings it to England, passes it to her brother, whence it is further decorated and offered to Jane Seymour.' Prof. Dobbins and I independently arrived at the conclusion that MS 1760 was prepared by Louis XII for Mary Tudor in 2005-6.

49 Alexander Robinson, 'Le Manuscrit “Magdalene College Pepys 1760” de Cambridge: Un miroir de la cour française pendant le règne de Louis XII (1498-1515)' (Master 2 diss., Université Paris IV Sorbonne, 2009). I am grateful to Mr Robinson for graciously sharing his dissertation with me in the summer of 2014, after I had been unable to obtain a copy of the document. 
worked according to a pre-existing plan. The entire musical contents of the Pepys MS fit neatly onto eleven quaternions of parchment, each consisting of four bifolios (see Tables 2 and 3). After the three canonic motets and Prioris's Dulcis amica dei on fols. I and $\mathrm{II}^{\mathrm{r}}$, all subsequent pieces begin on the verso side of the opening indicated by the foliation in the tabula on fols. $2^{\mathrm{v}}-3^{\mathrm{v}}$, and all are systematically organised according to genre and number of voices. Fol. II ${ }^{\mathrm{v}}$ starts a sequence of four-voice motets that extends up to fol. XXXVIII ${ }^{\mathrm{r}}$, a sequence broken briefly in fols. XXVIII $-\mathrm{XXXI}^{\mathrm{r}}$ in order to keep the $a 3$ second Lesson of the Lamentations in place between Lessons 1 and 3. Six three-voice motets ('Tabula aliorum verborum a3') fill fols. XXXVIII - XLVII ${ }^{\mathrm{r}}$ and end the sacred portion of the manuscript. The secular section of the manuscript ('Tabula Carminum') begins with a sequence of twentythree three-voice chansons (fols. XLVII - iiii $^{\text {XXIr }}$ ), but returns to larger settings for the final folios, which contain four secular songs for four or five voices (fols. iiii $^{\text {XXIv-iiii }}{ }^{\text {XXVIv }}$ ). Overall, the manuscript contents are precisely balanced, with three canons, twenty-seven non-canonic motets, and twenty-seven secular works. Given the amount of sacred music in MS 1760 and the religious inscription in red ink below the tabula, 'In laudem celestis regine', these numbers may not be purely fortuitous, since for millennia Christians have associated the number three (or, in the case of twenty-seven, $3 \times 3 \times 3$ ) with the godhead, with divine perfection. As will be shown later in this article, there is reason to suspect that the numbers of each type of piece included in MS 1760 were intended to have symbolic value.

The staves on all but two folios in MS 1760 appear to have been created with the same rastrum. There are music staves on all eighty-eight folios in the eleven quaternion gatherings, as well as on one unnumbered page (fol. $\left[{ }^{[} 7^{\mathrm{r}}\right]$ ) with different ruling that does not contain music or form a part of an identifiable gathering. With the exception of the two staves on the page that once bore a miniature portrait of Henry VIII, fol. I" , every page in the eleven quaternion gatherings appears to have been ruled with the same rastrum, and all staves are placed in exactly the same position on the page (which on occasion can make it difficult to tell if one is viewing lightly ruled staves or just the ink bleed-through from the staves on the opposite side of the folio). Every page in the eleven quaternions except for fol. $\mathrm{I}^{\mathrm{v}}$ leaves space for exactly eight staves. ${ }^{50}$ The nature of the differences between the ruling on fol. $I^{\mathrm{v}}$ and the rest of the body of the manuscript may be assessed by a comparison of fol. $4^{\mathrm{v}}$, the back side of the first folio of the eleven quaternions, with fol. Iv (see Figure 6) Figure 6

50 There are only seven staves on fol. II ${ }^{\mathrm{r}}$ because of the bottom gold decorative border, though the registration of the staves on the page precisely mirrors the stave registration on all other folios in the eleven quaternion gatherings except for fol. Iv. 
shows both the full ruling of fol. $4^{\mathrm{v}}$ and what one can see of fol. $4^{\mathrm{v}}$ by looking back through the hole left by the missing portrait on fol. $\mathrm{I}^{\mathrm{v}}$. The bottom line of the top stave of fol. $4^{\mathrm{v}}$ is visible through the top of the hole, as are staves $2-5$. It is clear from this view, however, that the two staves used for Gascongne's Ista est speciosa on the bottom of fol. $\mathrm{I}^{\mathrm{v}}$ are not on the same place on the page as the staves on fol. $4^{\mathrm{v}}$. This difference in stave registration also is apparent from the bleed-through of the staves on fol. $\mathrm{I}^{\mathrm{r}}$, which is visible behind Gascongne's canonic motet. Moreover, the two staves on fol. $\mathrm{I}^{\mathrm{v}}$ are slightly narrower than the staves used on fol. $4^{\mathrm{v}}$ and throughout the rest of the manuscript. Since ultraviolet examination yields no evidence that staves were erased from fol. $\mathrm{I}^{\mathrm{v}}$, it seems very probable that this page was not provided with staves when the rest of the manuscript received its ruling, but rather was left blank, with the two staves being added later, perhaps even after the illuminations, to judge from the severe crowding at the end of Gascongne's motet.

That either the current tabula or a comparable listing of the music in MS 1760 existed before the manuscript was copied is indicated by the presence of two distinct staving patterns within the manuscript. The eleven gatherings of music in MS 1760 have been bound to the spine of the book in two independent blocks, the first including gatherings $1-5$ and extending from fol. 4 through to fol. XXXIX[1], and the second including gatherings 6-11 and encompassing fol. XXXIX[2] through to fol. iiii ${ }^{X X V I} \cdot{ }^{51}$ Gatherings $1-5$ consistently have eight ruled staves per page, regardless whether a piece is for three or four voices, with blank spaces for initials on the left side of the first and fifth staves for either majuscules or illuminated flowers. ${ }^{52}$ The same can be said of the recto pages in gatherings $6-10$. But in deference to the fact that only a single voice-part appears on the verso pages in gatherings 610 (since every piece in those gatherings is a three-voice motet or chanson), the fifth staves do not have blank spaces for initials, and frequently there are blank spaces on those pages where staves 6 and 7 would have appeared had there been music for them. ${ }^{53}$ Stave 8 appears to have been consistently included in the verso ruling of gatherings $6-10$ because often the

51 When one opens MS 1760 to the end of gathering 5 at fol. XXXIX[1] ${ }^{\mathrm{v}}$ and the beginning of gathering 6 at fol. XXXIX[2] ${ }^{\mathrm{r}}$, there is a clear space between the gatherings sufficient to allow the reader to see all the way through to the back of the spine of the book. One can get some sense of this gap by looking at the DIAMM slide for fol. XXXIX[1] $]^{v}$, in which one can clearly see the gap as well as the threads used to bind the gatherings to the spine.

52 On several verso pages in gatherings $1-5$ blank spaces for initials on stave 5 have been filled in by hand, i.e., fols. XXXv ${ }^{\mathrm{v}}$ XXXVIII" , and XXXIX[1] $]^{\mathrm{v}}$. These spaces also have been filled in by hand in gathering 11 on fol. iiii ${ }^{\mathrm{XXIIIv}}$ and fol. iiii ${ }^{\mathrm{XXIII}}$, where three majuscules were needed on staves 1 , 4, and 7 for Richafort's a 5 D'amours je suys desheritée.

53 See, for example, fol. XXXIX[2] $]^{\mathrm{v}}$, staves 6-7 missing; fol. XLv , stave 7 missing; fol. XLI ${ }^{\mathrm{v}}$, staves 6-7 missing. 
music for the tenor or bass parts on the bottom recto side of openings could not be accommodated on four staves. Rather than continue the music onto the following verso page (which would have been very wasteful of space and would have wrecked the manuscript's organisational principle of having each piece start on the verso side of the opening indicated by the tabula), for many three-voice pieces the tenor or bass was completed on the bottom of the preceding verso page, with the continuation being indicated with one of the seven continuation signs used by the scribes who prepared MS $1760 .{ }^{54}$ Gathering 11 , which mostly is devoted to four- and five-part works, returns to the ruling pattern of gatherings $1-5$, with blank spaces for initials on staves 1 and 5. The conformity of the staving to the systematic organisation of the tabula leaves little doubt that the space required by the repertory of MS 1760 was calculated with exquisite care before the copying began.

Additional evidence that the total content of the manuscript was planned before MS 1760 was copied may be drawn from the relationship of the gathering structure to the individual compositions. Since there are no blank folios in the eleven quaternions of music after the tabula foliation starts, and since every piece after fol. II $^{\mathrm{r}}$ begins on the verso side of an opening, every gathering in MS 1760 except for the first begins with the completion of a piece that started in the preceding gathering, and all but the final quaternion end with the beginning of a piece that is completed on the following gathering. Thus not one of the gatherings is completely independent of its neighbouring gatherings. That the scribes were constrained by the limitations imposed by a pre-existent ordering and allocation of space is also evident in the variable spacing of different pieces. For example, the scribes who copied Brumel's Sub tuum presidium (fols. XVII $-\mathrm{XIX}^{\mathrm{1}}$ ) were able to leave entire staves blank and to space the music and text generously across four pages since the tabula granted them the equivalent of two full folios in which to copy the concise motet. In contrast, the spacing is much tighter and there are no blank staves for Mouton's Ave Maria (fols. XVv-XVI ${ }^{\mathrm{r}}$ ), for which the tabula allocates only a single opening of two sides.

The musician or musicians who planned MS 1760 and the scribes who copied it clearly were very concerned about the appearance of the finished product. There are no cancellations or erasures discernible to the naked eye in the music or their texts and there is remarkably little crowding of music, given the technical difficulties of calculating precisely how much space fifty-seven pieces of music would occupy. Gascongne’s single canonic part

54 For a listing of the continuation signs in MS 1760, see above, n. 19. Tenor or bass parts for threevoiced works are completed on the preceding verso pages on fols. XXVIII ${ }^{\mathrm{v}}, \mathrm{XXIX}^{\mathrm{v}}$, XXXIX[1] ${ }^{\mathrm{v}}$, $\mathrm{XL}^{\mathrm{v}}$, XLIII" ${ }^{\mathrm{v}}, \mathrm{XLVII}^{\mathrm{v}}, \mathrm{XLVIII}^{\mathrm{v}}, \mathrm{LI}^{\mathrm{v}}, \mathrm{LII}^{\mathrm{v}}, \mathrm{LIIII}^{\mathrm{v}}, \mathrm{LXI}^{\mathrm{v}}, \mathrm{LXVII}^{\mathrm{v}}, \mathrm{LXVIII}^{\mathrm{v}}, \mathrm{LXXII}^{\mathrm{v}}, \mathrm{LXXV}^{\mathrm{v}}$, LXXVII" and LXXVIII". 
on fol. $\mathrm{I}^{\mathrm{v}}$ had to be shoehorned into the space left by the folio illuminator, to judge from the severe crowding in the final measures of the piece, and crowding also may be discerned on fol. $\mathrm{XVI}^{\mathrm{r}}$ (where the final measures of the contratenor of Mouton's Ave Maria gratia dei plena had to be written at the end of the first stave of the bassus), the bassus on fol. XXVIr the contratenor on fol. XXVIII ${ }^{\mathrm{r}}$, the tenor on fol. XXXIII ${ }^{\mathrm{v}}$, the superius on fol. $\mathrm{XXXV}^{\mathrm{v}}$, the contratenor on fol. XXXVII ${ }^{\mathrm{r}}$, the contratenor on fol. LIIIr, the tenor continuation on the bottom of fol. LIIIIv, and the superius on fol. LVII". These places notwithstanding, the scribe(s) responsible for MS 1760 did a remarkable job of evenly spacing a large quantity of music and text in accordance with the dictates of the foliation given in the tabula. The neatness of their work suggests that by and large they were not copying new repertory, but rather pieces for which they had excellent exemplars.

There is one place, however, in which the music and text scribes could not accommodate the intent of the creator(s) of the tabula. Févin's three-voice motet $O$ preclara stella maris begins on fol. XXXVIII ${ }^{\mathrm{v}}$ and was intended to finish on fol. XXXIX ${ }^{\mathrm{r}}$, to judge from the foliations given in the tabula. In actual copying the motet extended one folio beyond its planned length, however, which required the scribe who wrote the red ink foliations on the upper right corner of each recto folio to introduce not one but two folios numbered XXXIX (see Table 2). Given the regular gathering structure of the manuscript, the doubled folios provide proof that the scribes who copied music and text into MS 1760 completed their portion of the work before the red ink foliation was added. Both the presence of the doubled folios and the fact that the music and text scribes must have copied MS 1760 without the benefit of the ink foliation strongly suggests in turn that the musical contents were copied in order from the beginning to the end of the manuscript. Finally, the doubled folios also suggest that the music and foliation scribes worked from what was considered the definitive version of the tabula when copying the manuscript and not an informal version, since if they had been working from an informal version presumably they would have corrected the foliation to reflect the actual pagination of the manuscript before adding the red ink foliation and making the final tabula.

The introduction of a second folio numbered XXXIX appears to have had ripple effects on the final execution and design of the manuscript. Composer attributions within the manuscript consistently are given above the music on the verso side of the opening beginning each piece, and the first page of each voice part typically begins with an illuminated majuscule drawn from the first word of the text. Continuations of pieces on subsequent folios have illuminations consisting of flowers, not letters, and do not provide attributions. The text scribes normally began the text of each voice part with a capital letter. 
When they were copying the beginning of a piece, they capitalised the second letter in the text, to allow the illuminator to provide the appropriate majuscule for the first letter. When they were copying the text on a second or third folio of a piece, however, where the practice was to provide flower illuminations instead of majuscules, the capital was the first letter of the word. The existence of several places where illuminated initials slightly overpaint music or text suggests that the illuminations normally were added after the music and texts. ${ }^{55}$

That this system occasionally broke down is indicated by a number of minor errors in the texts, illuminations and attributions, several of which appear in the folios surrounding the doubled folios XXXIX. The first error appears at the beginning of the superius part on fol. $\mathrm{XXXV}^{\mathrm{v}}$, the second opening of Mouton's [Benedicite] Dominus. Here the text scribe wrote a capital ' $\mathrm{O}$ ' for 'Dominus' as he had on the preceding pages for the same word at the beginning of Mouton's motet, where there were majuscules to provide the opening letter. He realised that the fol. $\mathrm{XXXV}^{\mathrm{v}}$ superius capital ' $\mathrm{O}$ ' was an error in time to correct it on the other three parts on fols. $\mathrm{XXXV}^{\mathrm{v}}$ and $\mathrm{XXXVI}^{\mathrm{r}}$ (which properly provide a capital 'D'), but rather than erase the capital ' $\mathrm{O}$ ' in the superius, he simply preceded it with a capital ' $\mathrm{D}$ '. This addition subsequently forced the illuminator to indent the lower right corner of the decorated flower that begins the superius part. Other errors in the decoration appear later in the manuscript. For example, on fol. LXXIII ${ }^{\mathrm{v}}$ the illuminator inserted a rose at the beginning of Pastourelle dieu te doint ioye rather than a majuscule, which forced the text scribe to insert an initial letter $\mathrm{P}$ after the illumination was painted. A similar mistake occurred on fol. LXXIX $^{\mathrm{r}}$, the first page of the tenor and bass parts for Gascongne's Celle quy ma demande, where the illuminator painted flowers and not majuscules of the letter ' $\mathrm{C}$ '.

The portion of the manuscript that caused the most problems for the illuminators and the scribes charged with adding majuscules and composer names was folios XXXVIII $-\mathrm{XL}^{\mathrm{v}}$, around the break between gatherings 5 and 6 , and the place where the foliation scribe was forced to insert two folios numbered XXXIX in order to stay with the foliation of the tabula. Févin's O preclara stella maris starts on fol. XXXVIII", in keeping with the tabula foliation of XXXIX for the motet. It does not, however, have a composer attribution above the superius part that opens the work, since the attribution to 'Anth[oine] de fevin' does not come until the following folio, fol. XXXIX[1] $]^{\mathrm{v}}$, which is also the last page in gathering 5 . The following folio, fol. XXXIX[2] $]^{\mathrm{r}}$, which provides the continuation of the tenor and bass parts for $O$ preclara, begins not with the expected floral illuminations, but rather with

55 Illuminations slightly overpaint music or text on fols. $V^{\mathrm{v}}, \mathrm{XI}^{\mathrm{v}}, \mathrm{XIV}^{\mathrm{r}}, \mathrm{XIV}^{\mathrm{v}}, \mathrm{XV}^{\mathrm{v}}, \mathrm{XX}^{\mathrm{r}}, \mathrm{XXII}^{\mathrm{r}}$, XXIII', XXIIII', XXVI ${ }^{\mathrm{r}}, \mathrm{XXXVI}^{\mathrm{v}}, \mathrm{XL}^{\mathrm{v}}$, and XLIr. 
majuscules of the letter ' $\mathrm{H}$ ', as if this were the beginning of another motet. The beginning of the following piece, Gascongne's Dulcis mater, is correctly laid out on fols. XXXIX[2] $]^{\mathrm{v}}$ $\mathrm{XL}^{\mathrm{r}}$ with a composer attribution at the top of the verso folio that starts the piece and majuscules of the letter ' $D$ ' on fols. XXXIX[2] ${ }^{v}$ and $\mathrm{XL}^{\mathrm{r}}$, but the second opening of the superius part on fol. $\mathrm{XL}^{\mathrm{v}}$ begins with a majuscule ' $\mathrm{Q}$ ' rather than the expected floral illumination. It is not clear why these mistakes occurred, though their proximity to the doubled folios XXXIX hints that they may be related to the extension of O preclara stella maris.

The extension of $O$ preclara apparently had one further effect on the structure of MS 1760. Given the tight organisation and execution of the eleven quaternion gatherings, there can be little doubt that the musician who planned the musical contents of the manuscript intended for it to begin with an empty but ruled folio (fol. 4). Had O preclara stella maris occupied the space that he intended there also would have been one empty but ruled folio at the end of the manuscript, a folio that would have been numbered iiii ${ }^{X X V I I}$ on top right recto. Because Févin's motet took up one extra folio, however, there was no blank folio at the end, and Consommo la vita mya was copied onto the back of a folio bearing the number iiii ${ }^{\mathrm{XXV}}$. It may be suggested that the reason one more ruled page, fol. [ $\left.87^{\mathrm{r}}\right]$, was inserted at the end of the manuscript was in order to balance out the opening ruled folio and to more closely match the appearance originally intended by the creator of the tabula order.

Because of the current binding of Pepys 1760 it is impossible to determine how the unruled folios at the beginning and end of the manuscript are physically connected to the 88 ruled folios in gatherings 1-11 (see Table 3), though a few observations can be made. Close examination of the binding reveals that fols. 1-2 and [88]-[89] (trimmed off and now missing) were single folded sheets of parchment. Given the regular structure of the manuscript, it seems possible that the front and rear paste-downs also originally were a single sheet, and the same may be true of fols. 3 and [87]. If these conjectures are correct, the pages surrounding the body of music would originally have comprised exactly one more quaternion of parchment. Given the formative role played by the tabula, these folios were not later additions, but rather were a part of the original conception of the manuscript.

In summation, the physical evidence presented by MS 1760 clearly indicates that the entire structural and musical content of the manuscript (including both the eighty-eight ruled folios and the unruled folios at the beginning and end) was laid out according to a preexistent plan. Given the regularity of the gathering structure and layout of the music, the precompositional existence of a tabula, the organisation of all music in the manuscript 
according to genre and/or scoring, the carefully planned stave ruling, and the uniformity of the original French illuminations and scribal hands throughout, it seems almost certain that its musical repertory and original French decorations were copied in their entirety as part of a single creative process for a particular purpose. The structure and organisation of MS 1760 provide no support for the theory that it was initially prepared for Louis XII but then repurposed as a wedding gift to Mary Tudor. ${ }^{56}$ Indeed, every aspect of the structure, layout and original decoration of the manuscript precisely replicates the characteristics that Joshua Rifkin has noted in connection with manuscripts that were 'written to plan': a high degree of regularity in both appearance and physical structure; uniform gatherings and the same script and decoration throughout; and organisation according to broader principles such as scoring and genre. ${ }^{57}$

\section{THE MISSING PORTRAIT AND THE TEXT 'ISTA EST SPECIOSA’}

Given the care that went into the planning and preparation of MS 1760, it can be demonstrated that the missing portrait of Henry VIII almost certainly was painted over an earlier miniature depicting the original owner of the manuscript. As noted above, the two decorated folios at the beginning of the Pepys manuscript must have been planned and executed at the same time as the rest of the manuscript, and could not have been later additions. Although they clearly belong to the earliest layer of MS 1760, differences in their musical content and decoration set them apart from the remainder of the manuscript, and suggest that they were intended to serve a specific function. These folios provide the only canonic pieces in the manuscript, one of which, Ista est speciosa, employs three to four times as many voice parts as every other piece save one. The canonic pieces and Dulcis amica dei also do not observe the systematic and symmetrical organisation of the remainder of the manuscript, which moves from four-voice motets to three-voice motets, to three-voice chansons, and back to four-voice secular works. Moreover, as we have noted, fol. $\mathrm{I}^{\mathrm{v}}$ was not ruled in the same manner, and probably not at the same time, as the rest of the manuscript, almost certainly because its miniature portrait demanded an organisation and spacing different from the other folios. Finally, fols. $\mathrm{I}^{\mathrm{v}}$ and $\mathrm{II}^{\mathrm{r}}$ provide by far the most elaborate artwork in the manuscript, artwork apparently created by either one of the leading painters at the French royal court, Jean Bourdichon, or a member of his atelier.

The purpose of the opening decorated folios would appear to be to frame and

56 This was recently suggested by Alexander Robinson in 'Le Manuscrit', 54-69.

57 Joshua Rifkin, 'The Creation of the Medici Codex', Journal of the American Musicological Society, 62 (2009), p. 519. 
contextualise their centrepiece, the missing miniature portrait on fol. $\mathrm{I}^{\mathrm{v}}$. Such miniatures are not uncommon in illuminated manuscripts created by and for English royalty during the fifteenth and early sixteenth centuries, a number of which may be found in the British Library, but no other extant French music manuscript from the first two decades of the sixteenth century contains such a portrait. ${ }^{58}$ Although this type of miniature is common in contemporaneous music manuscripts from the Low Countries, few have portraits that dominate the page to the extent of the missing portrait on fol. $\mathrm{I}^{\mathrm{v}}$ of MS $1760 .{ }^{59}$ In illuminated manuscripts from this period miniature portraits often function like the Pepys bookplates in MS 1760, to demonstrate ownership of a book or manuscript. When a manuscript was commissioned by a patron for personal use, the portrait portrays the person who commissioned the work. When manuscripts were gifts, they show the recipient, or sometimes both the giver and the recipient. Devotional books from the French royal court such as the Grandes heures d'Anne de Bretagne, the Hours of Louis XII and the Hours of Charles VIII include elaborate portraits of their royal owners accompanied by various saints, including the founder of the Carolingian line, Charlemagne (see Figure 7). ${ }^{60}$

The fact that the English heraldry on the opening folios of MS 1760 was painted over

58 The following illuminated manuscripts in the Royal Collection of the British Library, among others, contain portraits of English monarchs and members of the royal family: Royal $1 \mathrm{C}$. v; Royal 2 A. xvi; Royal 2 A. xix; Royal 2 V. i; Royal 12 B. vi; Royal 15 E. iv; Royal 15 E. vi; Royal 17 D. iii; Royal 18 E. ii; Royal 19 A. v; Royal 19 A. xxii; Royal 19 C. vi; Royal 19 C. viii; Royal 20 A. ii; Royal 20 B. iv; and Royal 20 B. vi (see the British Library websites www.bl.uk/manuscripts/ and www.bl.uk/catalogues/illuminatedmanuscripts/welcome.htm). A review of the sixteen extant music manuscripts identified by the Census-Catalogue as having originated in France between 1500 and 1525 (v. 278) indicates that Pepys 1760 is the only one that once contained a miniature portrait.

59 The following MSS from the Netherlands court complex of music manuscripts contain donor/owner portraits (see H. Kellman (ed.), The Treasury of Petrus Alamire: Music and Art in Flemish Court Manuscripts 1500-1535 (Ghent and Amsterdam, 1999), pp. 67-167): BrusBR 228; BrusBR 9126; BrusBR 15075; JenaU 3; JenaU 4; JenaU 5; MechAS s.s.; VatS 160; VienNB 1783; VienNB mus. 15495; and VienNB mus. 15947. The essays in Kellman's volume describe all of the portrait subjects as 'donors', although it is clear from the discussion of the manuscripts that these 'donors' owned the manuscript in which their portrait appears.

${ }^{60}$ Concerning the Hours of Louis XII, see the fascinating essays in T. Kern and M. Evans (eds.), $A$ Masterpiece Reconstructed: The Hours of Louis XII (Los Angeles and London, 2005). See also J. Backhouse, 'Hours of Henry VII', in T. Kren (ed.), Renaissance Painting in Manuscripts: Treasures from the British Library (New York, 1983), pp. 1-20; and F. Avril and N. Reynaud, Les Manuscrits à peintures en France 1440-1520 (Paris, 1993), pp. 294-6. On the Hours of Charles VIII, see J. Backhouse, 'Jean Bourdichon and the Hours of Louis XII', in A Masterpiece Reconstructed, p. 7. Anne's picture in the Grandes heures shows her in front, accompanied by her three patron saints, Ursula, Anne and Catherine. Louis XII's hours show him with Saint Michael the Archangel, Charlemagne, Saint Louis and Saint Denis. The owner portrait in Charles VIII's book of hours includes Charlemagne. 
French decoration and text clearly indicates that Henry VIII was not the subject of the original miniature on fol. Iv . Heraldry is used to honour and identify either the person who commissioned a manuscript or the person to whom it was given. ${ }^{61}$ The tightly planned structure of Pepys 1760 could not have arisen from a commission from Henry, since in a manuscript he commissioned for his own use he would have insisted on original shields of Saint George, not the overpainted shields of Saint Michael, and if he commissioned it to give it as a gift he would not have placed a solo portrait of himself in such a prominent place. Likewise, MS 1760 could not have been originally conceived as a gift from a male member of the French nobility to Henry VIII (a possibility suggested by the St Michael shields and the portrait of the king), because in such a gift it would not have been necessary to overpaint the St Michael shields and the English royal arms would not have been painted over a portion of the Latin text above the tabula. Given that MS 1760 almost certainly originated at the French royal court, the presence of original heraldry associated with the French military order strongly suggests that the manuscript was created as the result of a commission by a male member of the French nobility either for his own use or to be used as a gift to another member of the court, although one cannot rule out the possibility that it was commissioned by a female member of the French royal court for presentation to a male member of the court. Regardless which of these two possibilities is correct, Henry's portrait could not have been original artwork, but must have been painted over either an earlier portrait or blank parchment. The latter possibility seems highly improbable, given the detailed planning that went into MS 1760 and the meticulous decoration of fols. $\mathrm{I}^{\mathrm{v}}$ and $\mathrm{II}^{\mathrm{r}}$. That someone at the French royal court commissioned the overpainting of an original portrait, the beginning of the inscription above the tabula, and the Saint Michael shields so that the manuscript could be re-gifted to Henry VIII seems very possible, since owner-portrait overpainting was common at the court of Louis XII when manuscripts changed hands. The king depicted kneeling in front of Charlemagne in Figure 7c actually is Louis XII himself and not Charles VIII, since the former's visage and heraldry was painted on top of the latter's after Louis

61 The following manuscripts from the Netherlands court complex discussed in Kellman, The Treasury of Petrus Alamire, have portraits and heraldry that agree: BrusBR 228; BrusBR 9126; BrusBR 15075; JenaU 3; JenaU 4 (which has ten donor/owner portraits and six coats of arms); JenaU 5; MechAS s.s. (which has a single portrait containing ten figures and four coats of arms); VienNB 1783; VienNB mus. 15495; and VienNB 15497. Kellman's volume describes all of these manuscripts as the property of the subject or subjects depicted in the portrait(s). VatS 160, on the other hand, has a portrait of Pope Leo X (r. 1513-21) and his heraldry, but also heraldry from Portugal and Hungary. The addition of the latter emblems, which are associated with the Habsburgs, suggested to Flynn Warmington that the manuscript was a gift to Leo between 1513 and 1521 from Margaret of Austria or Archduke Charles (Kellman, The Treasury of Petrus Alamire, pp. 135-6). 
acquired the manuscript. Moreover, Louis also had his own face painted over an earlier owner-portrait when after his accession to the throne in 1498 he came into possession of a copy of Ptolemy’s Cosmography that previously had been the property of Louis of Gruuthuse (1422-92). ${ }^{62}$

Analysis of the text appearing directly under the missing portrait on fol. $\mathrm{I}^{\mathrm{v}}$, Ista est speciosa inter filias Jherusalem (She is the most beautiful of the daughters of Jerusalem), argues strongly that the original portrait depicted a woman. Given that Gascongne’s canon appears to have been added to fol. $\mathrm{I}^{\mathrm{v}}$ very late in the copying process, perhaps even after the painting of the illuminated majuscule with its paired rose and lily and the larger lilies, roses and insects on the gold background, and given the specificity and directionality of the motet text, it is difficult not to see it as a caption for the painting immediately above it, one that praises the beauty of the subject of the portrait. The imagery of this text and the one immediately preceding it in MS 1760, Quae est ista quae ascendit per desertum (Who is this that rises up from the desert), are derived from the great biblical love song the Song of Songs. Quae est ista quae ascendit quotes Song of Songs 3:6, which refers to Solomon coming on a litter as a bridegroom to meet his bride. The text of Ista est speciosa does not actually appear in the Song of Songs, though some of its words may be found in chapter 2 . Indeed, the Catholic liturgy from the Middle Ages to the present does not associate these texts with Solomon at all, but rather principally with the Virgin Mary, since during the Middle Ages the text 'Ista est speciosa inter filias Jerusalem' appeared in several different antiphons and responds that were used for a variety of Marian feasts. Given the literal meaning of the text, its strong Marian associations, its placement directly under the missing portrait, and the careful planning and preparation evident throughout MS 1760, it is inconceivable that this particular text would have been placed where it was if the original portrait depicted a man. ${ }^{63}$

The liturgical associations of the 'Ista est speciosa' text with the Virgin Mary might suggest that the original portrait depicted the Blessed Virgin herself. This would be in keeping with the inscription under the tabula, 'In laudem celestis regine'; the depiction on fol. $\mathrm{I}^{\mathrm{v}}$ of a ladybird and a butterfly, insects associated in France with the Virgin Mary and

62 See Backhouse, 'Jean Bourdichon and the Hours of Louis XII', pp. 7-9.

63 Alexander Robinson proposed that the Bernard catalogue description of the missing portrait as a 'Prince of Wales' was mistaken, and that the original portrait depicted Louis XII (Robinson, 'Le Manuscrit', pp. 63-9). This is contradicted by Burney’s testimony as well as the evidence adduced here suggesting that the original portrait depicted a woman. 
marriage as far back as the sixteenth century; ${ }^{64}$ and the domination of the first part of the manuscript by motets that refer to Mary. Every one of the first fifteen motets in MS 1760 either sets a text used in Marian liturgies or refers to the Virgin, as do five of the six threevoice motets. In all, fully two-thirds of the motets in the Pepys manuscript either explicitly honour the Virgin Mary or employ texts used in Marian liturgies. The main themes expressed by these Marian motets are (1) the Annunciation; (2) Mary’s virginity, fertility and motherhood; and (3) prayers for her intercession. This hypothesis concerning the original subject of the miniature, however, does not explain why MS 1760 also contains Lamentation settings and chansons, nor does it provide any indications for whom the manuscript was prepared at the French royal court, although in contemporary devotional books from the royal court such miniatures uniformly do depict the owner. Finally, it raises the question why a portrait of the Virgin Mary would have been painted over with a portrait of Henry VIII when the manuscript was re-gifted to that monarch.

Further study of the liturgical assignment of 'Ista est speciosa' yields an alternative hypothesis concerning who originally was depicted in the missing miniature. According to Carl Marbach’s Carmina scripturarum, this text traditionally was used as a respond sung at the processional entrance of queens and empresses. ${ }^{65}$ The same liturgical assignment may be found for Ista est speciosa in the Processionale monasticum ad usus congregationis gallicae Ordinis Sancti Benedicti and in the Pontificalis liber (1485) of Patrizi Piccolomini (143595), secretary to Pope Pius II and President of the College of Ceremonies at the papal court in $1485-8 .{ }^{66}$ The latter source provides the following description of the liturgy for the

${ }^{64}$ On associations of the ladybird and butterfly with the Virgin Mary and marriage, see P. Sébillot, Le Folk-lore de France, iii: La faune et la flore (Paris, 1906), pp. 308, 321-2. According to Sébillot, the ladybird traditionally was called bête du Paradis (creature of Paradise) in Hainaut and petite bête de la vierge (little creature of the Virgin) in Flanders. For more on European folk associations of the ladybird with the Virgin Mary, see H. Gradl, 'Zur kunde deutscher Mundarten’, Zeitschrift für vergleichende Sprachforschung auf dem Gebiete des Deutschen, Griechischen und Lateinischen, 19 (1870), p. 57, and A. F. Pott, 'Religiöse Beziehungen in Namen von Naturgegenständen', Zeitschrift für vergleichende Sprachforschung auf dem Gebiete des Deutschen, Griechischen und Lateinischen, 4 (1855), pp. 174-5.

65 'R. Ista est speciosa in Ordine ad recipiendam processionaliter Imperatricem vel Reginam'. C. Marbach, Carmina scripturarum scilicet antiphonas et responsoria ex sacro scripturae fonte in libros liturgicos Sanctae Ecclesiae Romanae (Strasbourg, 1907; repr. Hildesheim and New York, 1994), p. 277.

66 Processionale monasticum ad usus congregationis gallicae Ordinis Sancti Benedicti (Solesmes, 1893), pp. 312-13; Il 'Pontificalis liber' di Agostino Patrizi Piccolomini e Giovanni Burcardo (1485), ed. M. Sodi (Monumenta studia instrumenta liturgica; Vatican City, 2006), pp. 537-9. 
Processional Reception of an Empress or Queen: ${ }^{67}$

$<$ EXT $>$ Order for the Processional Reception of an Empress or Queen, when the Empress or Queen goes to any city or notable town. The clergy shall go in procession to meet her outside the gate. The Empress or Queen shall kiss the cross, which shall be offered by the prelate. Next she shall be led under the baldachin up to the church in the customary order. In the meantime shall be sung the responsory 'Ista est speciosa inter filias hierusalem. Sicut vidisti eam plenam caritate et dilectione in cubilibus et in ortis aromatum. V. Ista est speciosa quae ascendit de deserto deliciis affluens. Sicut vidisti. V. Gloria patri. Sicut vidisti.’ Next let there be sung hymns or other more pleasing songs. When the Empress or Queen enters the church the priest, having taken the aspergillum, should sprinkle her. Next the others according to their kind, and they should proceed up to the main altar. Here the Empress or Queen should genuflect upon the faldstool prepared for her there and pray. The priest however should ascend before the same altar, where, standing facing the one in prayer, with uncovered head, and says: V. Save your handmaiden, Lord. R. My God, trusting in you ... [prayers] ... Next the priest, if he is a bishop or greater, solemnly blesses the people. Then, the clergy having put away their robes, the Empress or Queen is accompanied to the guest room. $<$ EXT/>

Given the consistent evidence provided by the musical repertory and decoration of MS 1760, the liturgical use of Ista est speciosa as the first song sung at the Processional Reception of an Empress or Queen raises the possibility that the original subject of the miniature portrait was one of two women who ruled France as queen during the reign of

67 The full passage reads as follows: 'Ordo ad recipiendam processionaliter Imperatricem vel Reginam. Quando Imperatrix vel Regina ad aliquam urbem aut insigne oppidum venit. Clerus processionaliter obviam dat ei extra portam. Imperatrix vel Regina osculatur crucem que per prelatum sibi porrigitur. Deinde sub baldachino ducitur usque ad ecclesiam ordine consueto. Interim cantatur responsorium. Ista est speciosa inter filias hierusalem. Sicut vidisti eam plenam caritate et dilectione in cubilibus et in ortis aromatum. V. Ista est speciosa quae ascendit de deserto deliciis affluens. Sicut vidisti. V. Gloria patri. Sicut vidisti. Deinde cantentur hymni vel alia cantica magis placentia. Cum Imperatrix vel Regina ecclesiam intrat prelatus accepto aspersorio aspergat eam. Deinde alios in genere, et procedant usque ad altare maius. Coram quo Imperatrix vel Regina genuflectat super faldistorio ibidem sibi parato et oret. Prelatus vero ascendat ante idem altare. Ubi stans versus ad orantem, detecto capite dicat: V. Salvam fac ancillam tuam Domine. R. Deus meus sperantem in te. . V. Dominus vobiscum. R. Et cum spiritu tuo. Oremus. Deus cuius providentia in sui dispositione non fallitur. Ineffabilem clementiam tuam supplices ex oramus ut sicut Hester Reginam Israelitice plebis causa salutis ad Regis Assueri thalamum, regnique sui consortium transire fecisti, ita hanc famulam tuam Christiane plebis salutis gratia, ad gratiam tuam transire facias ut tibi super omnia iugiter placere desideret, et te inspirante, que tibi placita sunt toto corde perficiat, et dextera tue potentie illam semper vicet ubique circumdet. Per Christum Dominum nostrum. R. Amen. Deinde prelatus si sit episcopus vel maior solemniter populo benedicat. Tum sacris dimissis vestibus, Imperatricem vel Reginam usque ad hospicium comitetur.' 
Louis XII, Anne of Brittany or Mary Tudor.

The possibility that the original miniature depicted Queen Anne is initially appealing on several counts. Much of the musical repertory in the manuscript appears to have been created for the delectation of the French royal court during the period that she reigned over France (queen consort 1491, crowned queen of Charles VIII at St-Denis on 8 Feb. 1492, re-crowned queen of Louis XII 18 November 1504, died 9 Jan. 1514), and since over a third of the manuscript's contents were written by one of her husband's favourite composers, Antoine de Févin, it requires no great stretch of the imagination to hypothesise that Pepys 1760 was commissioned by Louis XII so that he could present his wife with a gift of his favourite music. In this hypothesis, the heavy emphasis on texts emphasising the Virgin Mary's virginity and fecundity could have stemmed from the king's desire to encourage the queen in her attempts to bear a royal heir for the French throne, a process that was her central occupation during the twenty-four years of her marriages first to Charles VIII and then to Louis. ${ }^{68}$ The identification of Anne as the recipient also is in keeping with the appearance of the motet Adiutorium nostrum on fols. XXIII $-\mathrm{XXV}^{\mathrm{r}}$, a work that has been linked to her pilgrimages in 1508 and following to a chapel in the church of Angers devoted to St René, patron saint of mothers desiring sons. ${ }^{69}$ This theory might explain, too, why three lessons' worth of the Lamentations of Jeremiah as well as Richafort's somber motet Sufficiebat nobis were included, since the loss of numerous infants demonstrably deeply affected both Anne and Louis, and the text of the latter motet employs biblical words of lamentation spoken by Anna, wife of Tobias, when her only son left home in the company of the angel Raphael. Given the poignant subtext of Sufficiebat nobis, 'Mon souvenir my faict mourir' (My remembrance makes me die), and the existence of a papal supplication from the royal court in November 1512 requesting a benefice in Brittany for the composer, it seems possible that the motet was inspired by the death of a stillborn son to Louis and Anne in January 1512. ${ }^{70}$

68 Alexander Robinson suggested that Marian texts related to birth could have been included in MS 1760 in reference to Anne's attempts to produce an heir; 'Le Manuscrit', pp. 59-63.

69 On the Angers pilgrimage see S. Bonime, 'Anne de Bretagne (1477-1514) and Music' (Ph.D. diss., Bryn Mawr College, 1975), pp. 73-5; Brobeck, 'The Motet', pp. 204-6 and 'Antoine de Févin and the Origins of the Parisian Motet', in Thomas Schmidt-Beste (ed.), The Motet around 1500: On the Relationship between Imitation and Text Treatment? (Centre d'études supérieures de la Renaissance, Collection Épitome musical ; Turnhout, 2012), p. 320. The presence of Adiutorium nostrum in MS 1760 forms an important part of Alexander Robinson's argument that MS 1760 was originally prepared for Louis, then repurposed as a wedding gift to Mary Tudor.

70 On evidence linking Richafort to Louis XII and Anne of Brittany see the article on Richafort in Grove Music Online. The stillborn son of 1512 was Anne's sixteenth and final pregnancy. Sufficiebat nobis quotes Tobias 5:25, 5:24 and 10:4, portions of the biblical account that stress the 
Nevertheless, this hypothesis leaves unanswered questions. If the manuscript was intended for Anne, why is fol. $\mathrm{I}^{\mathrm{v}}$ dominated by the royal emblems of England and France, even in the majuscule of Ista est speciosa? Moreover, the presence of Adiutorium nostrum indicates that MS 1760 dates from not earlier than the final six years of Anne’s life and reign. Although the queen undoubtedly was beautiful to her husband and subjects at the end of her life, ardent texts drawing upon the imagery of the Song of Songs such as Ista est speciosa, Que est ista que ascendit, Quam pulchra es and Nigra sum are surprising in a gift from an aging monarch who was in poor health to his increasingly infirm queen, whose looks are reported to have rapidly faded after her marriage to Louis in 1499. Moreover, it is not clear why the musician or musicians who planned the manuscript would have inserted Nobilis progenie, a motet about Remegius, the founder of the French coronation rite, in a gift for Anne (who had been crowned queen of France not once but twice and who had reigned far longer than Louis); nor why he or they started the secular section of the manuscript with Févin's chanson cycle, which is devoted to the pitfalls of a couple mal marié; nor why the entire manuscript ends with a somber text speaking of unfulfilled desire such as Consommo la vita mya. Finally, if Anne was the original recipient and owner of Pepys 1760, it still remains to be explained how and when it was acquired by Henry VIII prior to 1528.

\section{MARY TUDOR’S ENGAGEMENT AND MARRIAGE TO LOUIS XII}

Review of the particular circumstances surrounding the lead-up to Mary Tudor's marriage to Louis XII on 9 October 1514 provides a more compelling explanation for the physical appearance and structure of MS 1760, the selection of its repertory, and the transference of the manuscript to England. When Anne died on 9 January 1514 Louis deeply and publicly mourned her passing, and even went into seclusion for several days. He supposedly told his courtiers 'go make the vault . . . big enough for us both. Before the year is over I'll be with her. ${ }^{71}$ The king wore black in mourning (which was against tradition for a French monarch, who always wore white for mourning), and insisted that anyone who spoke to him also be dressed in black. He even extended the mourning period well beyond the customary forty days into early May, which meant that all those who attended the wedding of his daughter

distress suffered by Anne the mother of Tobias fils when he left home in the company of the angel Raphael and was gone far longer than his parents expected. There is no reference in the motet text to the subsequent joyous homecoming of Tobias fils with his new wife Sara.

71 F. J. Baumgartner, Louis XII (New York, 1994), p. 235, citing P. de Brantôme, Oeuvres complètes, ed. L. Lalanne (Paris, 1864-82), vii, pp. 328-9. The most detailed description of Mary Tudor's engagement and marriage to Louis XII appears in E. A. Sadlack, The French Queen's Letters: Mary Tudor Brandon and the Politics of Marriage in Sixteenth-Century Europe (New York, 2011). 
Claude of France to François d'Angoulême on 14 May 1514 had to wear black. Even while externally in mourning, however, a mere two weeks after Anne's passing the Venetian ambassador to France Marco Dandolo could report that discussions had already begun about the king's remarriage, and that three possible brides had been named, Queen Margaret of Scotland (widow of James IV and sister of Henry VIII), Margaret of Austria and Mary Tudor. $^{72}$ These discussions proceeded rapidly, thanks to the presence at the English court of François Dunois, Duc de Longueville, who had been taken prisoner by the English army at the Battle of the Spurs in August 1513, but also acted as an unofficial liaison between the two royal courts, which had engaged in active warfare since 1511. Negotiations between Henry and the French court over a possible peace treaty and marriage contract were serious enough by late May that Louis sent over Thomas Bohier, one of his top financial advisers, to work out the financial arrangements. In June Henry proposed that Louis cede the cities of Thérouanne, Tournai and St Quentin to the English and pay them 1.5 million ducats in exchange for one of his two sisters, with a discounted price for Margaret, who was twentyfour years old. Louis held out for Mary, who was eighteen, and was widely reputed to be one of the most beautiful princesses in all of Europe. She played the lute and clavichord, and like many members of the English royal court, spoke French. Her beauty was such that Margaret of Austria's ambassador Gerard de Pleine could write: 'I assure you that she is one of the most beautiful girls one could ever wish to see and it doesn't seem to me that I have ever seen one so beautiful, she has very great grace and the most handsome manner that could be devised, in dancing or anything else possible to have, and she is not at all melancholy, but very entertaining. ${ }^{73}$ This opinion of Mary’s looks was widespread among contemporaneous commentators. Louis obtained approval to cede the cities to England from the Council of Notables on 16 July, and gave Bohier and Longueville a commission to sign a treaty of alliance and contract of marriage with Mary on 29 July that reduced the French court's total cash payout to 1 million crowns, to be paid twice a year at a rate of 26,315 crowns. Even this payment may not have been easy for the French government, which was running annual deficits of over 1 million livres tournois at the beginning of 1514, and incurred heavy expenses for Mary Tudor to come to France. ${ }^{74}$ A proxy wedding was conducted between the Duc de Longueville and Mary at Greenwich on 13 August, to be followed by a second proxy wedding in which Louis participated in France on 14 September that Mary did not attend. The actual wedding ceremony between Mary and Louis took place in Abbeville on 9

\footnotetext{
72 Baumgartner, Louis XII, p. 236.

73 Sadlack, The French Queen's Letters, p. 56.

74 Baumgartner, Louis XII, pp. 239, 206-7.
} 


\section{October 1514.}

In order to show his love and concern for his new bride, shortly after the Greenwich proxy wedding Louis sent Jean de Sains, Sieur de Marigny, to England to serve as a special attendant to Mary and to familiarise her with French manners and customs. He also sent his favourite court portrait painter Jean Perréal, who had been commissioned not only to paint a portrait of the 'French queen' but also to assist in the planning of her wardrobe so that it would conform to French tastes. The two men came to the English court bearing rich gifts, including a sensational jewel known as the Mirror of Naples that was described by an Italian merchant as a jewelled diamond as large as a man's finger, with a pear-shaped pearl beneath it 'the size of a pigeon's egg', all of which was assessed at 60,000 crowns. Since Mary had never seen her new husband, Perréal brought a portrait of him, to be given to Henry in exchange for the portrait of Mary that he was to paint and take back to Louis. ${ }^{75}$ Perréal may also have painted a portrait of Henry at this time, as suggested by a 1959 sale of a portrait attributed to the artist that Sotheby's catalogue describes as 'Henry VIII as a young man'. ${ }^{76}$ The earliest account of Perréal's trip to England appears in Werner Rolewinck's Fasciculus temporum, in the version published in Paris in 1524 by Jean Petit:

$<$ EXT $>$ At the same time, Louis hears that Mary, sister of the king of England, is of such great beauty that she would be judged worthy of marriage. The loins of the old man are aroused and his languishing spirit seemed to be revivified. Thus he appoints John of Paris [Perréal], another Apelles, to go to England to portray the form of Mary. By means of which the king, always greatly commending it, wins over his chiefs, otherwise resistant, to his desires. The ambassador [Thomas] Bohier asks in the name of the king that Mary be his consort. Finally at Abbeville they celebrate the wedding. After the nuptials were celebrated, the accompanying French arrived in Paris. When the queen, bringing peace to the extent that she could, was triumphantly received, all prepared to share in

75 A convincing case has been made that an anonymous portrait of Louis XII now in the Royal Collection at Windsor Castle was the portrait brought over to England by Perréal (see below, Figure 9.a). See J. Dupont, 'A Portrait of Louis XII Attributed to Jean Perréal', Burlington Magazine for Connoisseurs, 89, no. 534 (Sept. 1947), pp. 234-9.

76 A portrait attributed to Jean Perréal titled 'Henry VIII as a young man’ was sold as Lot 56 by Sotheby's in London on 25 Feb. 1959 for $£ 160$. See http://artsalesindex.artinfo.com/asi/lots/3258214. Any portrait by Perréal of Henry VIII painted prior to 1519 almost certainly would have depicted him without a beard, as demonstrated by the dendrochronological studies of a series of early portraits of English monarchs conducted by John Fletcher in the 1970s. Much of the relevant recent scholarly literature pertaining to Henry VIII's early portraiture is summarised effectively by Pamela Tudor-Craig in 'Iconography of the Painting', in Martin Biddle (ed.), King Arthur's Round Table: An Archaelogical Investigation (Woodbridge, Suffolk, 2000), pp. 308-15. 
the joy of the king. ${ }^{77}<\mathrm{EXT} />$

When Louis saw the portrait, he said he was 'more pleased to have so beautiful a wife than half his state' and was said 'to yearn hourly for her presence'. ${ }^{78}$ Louis, though fifty-two, sickly and afflicted with gout, was very eager to meet his beautiful young bride, and corresponded with her regularly after the contract was signed.

The match was widely derided throughout Europe. In Flanders the Dutch decried the idea 'that a feeble, old, and pocky man should marry so fair a lady'; and the Emperor Maximilian also pretended horror that Mary should be sacrificed to 'an impotent, indisposed, and so malicious a prince' as the French king. ${ }^{79}$ Moreover, Louise of Savoy, who was intensely protective of her son François d'Angoulême and intended to do everything in her power to make sure that he succeeded Louis after his death, sourly noted in her diary on 22 September that Louis, 'exceedingly old and weak' ('fort antique et débile'), had left Paris to meet 'his young wife' ('sa jeune femme'). On 9 October, the day of Louis and Mary's wedding at Abbeville, she observed with some disgust that the 'amorous wedding' between Louis and Mary took place at 10 in the morning and then that evening they went to bed together. ${ }^{80}$ Perhaps the worst were the law clerks (the basoche) of Paris. The French chronicler Robert de La Mark, Seigneur de Fleurange, identifies them as the source of a quip that circulated in Paris in November 1514, 'le roy d’Angleterre avoit envoyé une haquenée au roy de France,

77 'Eodem tempore, Ludovicus audit Mariam, regis Anglie sororem, tante esse venustatis ut regis thoro digna censeretur. Concitantur senis medulle, et languescens animus redivivus effici visus est. Destinat itaque ad Angliam Johannem Parrhisiensem, alterum Apellem, qui Marie formam effingat. Quam ut accepit rex, semper illam commendans, in sua vota primores alioquin refragantes conciliat, Boheirus caduceator et nomine regis mariam conthoralem fore deposcit. Tandem apud Abbetisvillam hymenea celebrant. Quibus celebratis reduces galli parrhisios adveniunt. Ubi regina ut pote pacem adferens triumphanter excepta est/ ac regis gaudio cuncti considere parabant.' http://gallica.bnf.fr/ark:/12148/bpt6k52505k/f198.image.r=Fasciculus\%20temporum\%20.langEN . My most sincere thanks go to Dr Cynthia White of the University of Arizona for assisting me with this transcription and translation.

78 Baumgartner, Louis XII, p. 240. Other accounts of Perréal's trip to England appear in W. C. Richardson, Mary Tudor, the White Queen (London, 1970), p. 82; M. Perry, The Sisters of Henry VIII: The Tumultuous Lives of Margaret of Scotland and Mary of France (New York, p. 1998), 90; E.-M. Bancel, Jehan Perreal dit Jehan de Paris, peintre et valet de chambre des rois Charles VIII, Louis XII et François I ${ }^{\text {er }}$ : Recherches sur sa vie et son oeuvre (Paris, 1885), pp. 139-41; and R. Maulde de La Clavière, Jean Perréal dit Jean de Paris, peintre de Charles VIII, de Louis XII et de François $I^{\text {er }}$ (Paris, 1896), pp. 52-3. Maulde de La Clavière places Perréal in London in Sept. 1514.

79 Richardson, Mary Tudor, p. 80.

80 Sadlack, The French Queen's Letters, pp. 73-4. 
pour le porter bientost et plus doucement en enfer ou en paradis' (the king of England had sent a hackney horse to the king of France to carry him more swiftly and more sweetly to Hell or to Paradise). As Charles Giry-Deloison has observed, this is a somewhat more acidic comment than appears at first glance, since in both English and French the term hackney could mean not only a filly, but also a prostitute. ${ }^{81}$

\section{THE SYMBOLISM OF MARY TUDOR’S ROYAL ENTRÉES AND MS 1760}

Mary crossed the English Channel on 2 October 1514 in rough weather that scattered her accompanying flotilla. After she reached France her appearance was celebrated with royal entries into four cities, Boulogne on 2 October, Montreuil-sur-mer on 5 October, Abbeville on 8 October (where her official wedding to Louis was enacted the following day), and Paris on 6 November. We know quite a bit about these entries, since contemporary accounts have survived for all four. ${ }^{82}$ Charles Giry-Deloison has studied these documents in depth, and not only has identified several main themes, but also convincingly explained much of the symbolism present in the entries. ${ }^{83}$ These themes included passage; youth and beauty; the Garden of Eden; and the Virgin Mary. One of the principal props used in three of the four entries was a ship or boat, which symbolised the crossing of borders. Ships were the only physical link between England and France, and thus they symbolised crossing the divide that had separated the two kingdoms during their recent warfare. The boat also symbolised crossing the gap between youth and old age, as represented by Mary and Louis. One of the main themes in the entries was Mary's beauty, which all commentators agreed upon. At Boulogne she was described as 'la belle et triumphant pucelle, plaine d'honneur, de biauté et

81 C. Giry-Deloison, “"Une haquenée ... pour le porter bientost et plus doucement en enfer ou en paradis”: The French and Mary Tudor's Marriage to Louis XII in 1514', in D. Grummitt (ed.), The English Experience in France c. 1450-1558: War, Diplomacy, and Cultural Exchange (Aldershot, 2002), pp. 132-4.

82 The Boulogne entry is described in Jacques Leest, Entrée solennelle de Marie d'Angleterre seconde femme de Louis XII en la ville de Boulogne le . . . septembre 1514, ed. Abbé D. Haigneré (Almanach de Boulogne ; Boulogne, 1863), pp. 85-90. Haigneré republished Leest's account in 'Réception solennelle de Marie d'Angleterre à Boulogne', Recueil historique du Boulonnais (notices, articles, éphémérides), 1845-1893, III (Boulogne-sur-mer: G. Hamain, 1899), 71-5. The account of the Monstreuil entry appears in F. Wormald, 'The Solemn Entry of Mary Tudor to Montreuil-sur-mer in 1514', in J. Conway Davies (ed.), Studies Presented to Sir Hilary Jenkinson (London, 1957), pp. 471-9. Several archival and published accounts of the entries into Abbeville and Paris are summarised in Giry-Deloison, “'Une haquenée”', pp. 139-43.

83 Giry-Deloison, “'Une haquenée”, pp. 152-8. The following two paragraphs summarise and closely paraphrase Giry-Deloison’s superb analysis of Mary’s four entries. For additional insight into Mary's preparations for France, and the specific circumstances surrounding her trip in Oct. 1514, see also Sadlack, The French Queen's Letters. 
de sens', at Monstreuil 'doulce et debonnaire', at Abbeville 'très belle honeste \& joyeuse', at Paris 'belle et bonne', and she was also praised for her 'beaulté excellente . . . eminente'. Maître du Breul of the University of Paris noted that her beauty was not only physical, but also spiritual, and reflected her possession of 'beaulté en l'âme'. Since the entries describe war as a 'monstre merveilleux et dommaigeable', Mary's beauty was seen as the opposite, as the epitome of peace, and the entries uniformly credit her with creating peace. Peace also was represented by the allegoric union of the lily of France and the rose of England, and Mary herself is described as a rose (e.g., the creator of the seven pageants for the Parisian entry, Pierre Gringore, described her as 'la rose figurant Marie’). The pageant at the Holy Innocents in Paris compared France to a pleasant garden full of lilies, where roses could happily flourish. In the rhetoric of the entries, the union of the lily and the rose brought together the parc de France and the pays d'Angleterre, thus recreating on earth the perfection of the Garden of Eden where discord and war were unknown. The desire for peace is also reflected in a pageant by Gringore in which Louis was compared to Solomon and Mary to the Queen of Sheba. The point of the pageant was to express the hope that even as the joining of Solomon and the Queen of Sheba brought peace, so the marriage of Louis and Mary would bring peace.

That Mary Tudor, like the mother of Jesus, was a virgin named Mary was no coincidence to the French, but rather was a gift from God. Her name carried great significance in France, since Louis XII had dedicated his kingdom to the Virgin Mary. Gringore began his first tableau vivant by praising God for the good he had bestowed upon the French people by sending Mary Tudor, and concluded his final tableau with a poem comparing 'Marie au ciel et Marie en la terre'. Maître du Breul referred to the new queen as the 'estoille de la mer' (star of the sea, in Latin stella maris) that saved those in danger of death, and drew parallels between Mary marrying Louis and the Virgin Mary giving birth to the Son of God. Many of the entry pageants emphasised similarities between the Virgin Mary and the new queen, who was described as her 'godchild' and was believed to share her attributes. For example, the third tableau of the Montreuil entry showed the Virgin Mary and the 'Salutacvion [sic] Angelique' (the Annunciation), which frequently is noted in the entries as the model for the marriage of Mary and Louis, and similarly in Paris the last pageant showed the Angel Gabriel saluting the Virgin Mary with the words 'Ave gratia plena' across a swath of lilies while both looked down upon Louis and Mary, who were seated below in a garden of lilies. This visual comparison of the royal marriage with the Annunciation was accompanied by verse that explicitly compared the peace brought between God and mankind through the Annunciation with the peace brought by Mary Tudor through her marriage to the king and 
the French people.

Many of these themes and symbols are readily apparent in a detailed account of the first royal entry at the city of Boulogne recorded by Abbé Jacques Leest of the monastery of StWulmer in Boulogne, after a text written by the prior of the monastery, Leurens Framery (see Appendix II). The Boulogne entry included a boat decorated with roses and fleurs-de-lis that hung above the bridge at the entrance to the town. In this boat was a young girl who was cast in the role of the Virgin Mary and two children dressed as angels. These young people not only bore the town's gift to Mary (a silver swan containing a heart of gold worth 60 écus d'or), but also welcomed her to the town with the words 'Que est ista que ascendit per desertum sicut virgula fumi ex aromatibus mire et thuris?', to which the first angel responded 'Ista est speciosa inter filias', followed by French poetry that compared Mary to 'the flowering rose of beauty' and identified her as the 'filloeulle' (godchild) of the Virgin Mary, who would bring an end to warfare through her marriage to 'the most Christian king'. The second angel noted 'and flowers of rose and lily surrounded her', followed by more poetry mentioning the lily and rose, praise to God, 'the king of Paradise', and a hearty welcome to the new queen. After this the queen entered the town and walked up to the church of Notre Dame, where presumably the remainder of the liturgical Order for the Processional Reception of an Empress or Queen as recorded in the Pontificalis liber (1485) was enacted.

The Boulogne entry of Mary Tudor closely mirrors the texts and imagery of the opening folio of MS 1760. The boat, like fol. $\mathrm{I}^{\mathrm{v}}$ of the manuscript, was 'bien paint de fleurs de lys et de rozes'. The young woman in the boat who played the part of the Virgin Mary apparently did not speak the first text in the Pepys manuscript, the angelic salutation spoken at the time of the Annunciation, 'Ave Maria gratia plena', since she herself was the object of that text, but she did speak the exact words of the second motet, 'Que est ista que ascendit per desertum sicut virgula fumi ex aromatibus mire et thuris', which were answered by the first angel with the words of the third motet, Gascongne's twelve-voice canon Ista est speciosa inter filias Jherusalem, words directed in the entry to Mary Tudor herself, who stood before the young people at the gate to Boulogne. In MS 1760 this text was reproduced directly underneath a portrait surrounded by 'flores rosarum et lilia convallium' that may well have depicted Mary Tudor, who was famed for her beauty, whose wedding to Louis XII brought together the Tudor rose and the lily of France in peaceful union, and whose portrait would have been readily available to someone at the French royal court who wished to create a gift for a music-loving young queen, thanks to the labours in August and September 1514 of Louis XII's favourite painter Jean Perréal, who had painted Mary in England just a matter of 
weeks prior to her arrival in France. Given the French view of the Virgin Mary and Mary Tudor's status in the entries as her godchild, the ladybird on fol. IV could be a reference to either or both Marys. The butterfly's traditional association in French folklore with marriage would have had clear significance for Mary Tudor.

Although de Leest's account of the entry at Boulogne makes sense of both the textual and decorative content of fol. $\mathrm{I}^{\mathrm{r}-\mathrm{v}}$, it does not provide any indication why the musician(s) who planned MS 1760 selected Prioris’s Dulcis amica dei for the remaining fully decorated folio, fol. II $^{\mathrm{r}}$. The rather somber sentiment of this motet text, 'Dulcis amica dei, rosa vernans, stella decora; Tu memor esto mei dum mortis venerit hora' (Sweet friend of God, blossoming rose, beautiful star; Remember me when the hour of death comes), initially seems out of place in MS 1760 if the manuscript indeed was created as a wedding gift for Mary Tudor. According to Ulysse Chevalier, this text appears as a prayer to the Blessed Virgin in a fifteenth-century book of hours from Angers. ${ }^{84}$ But close parallels between its textual imagery and the language used in Mary’s entries suggests that in late 1514 it also may have been intended to convey a personal message to the new queen.

The tableaux vivants performed during Mary's entries explicitly compare her to the Virgin Mary, address her as amica (friend), and refer to her as a rose or a star. The third tableau vivant of the Parisian entry had the following text written below the platform where the entertainment was presented: 'Veni amica mea, veni coronaberis. Canticorum 40' (Come my friend, Come be crowned. Song of Songs $\left.4^{0}\right) .{ }^{85}$ As previously noted, Gringore called Mary 'la rose figurant Marie' and Maître du Breul identified her as the 'très belle estoille de la mer' (very beautiful star of the sea) who saves those in danger of death. ${ }^{86}$ Further explanation of the significance of the term 'star of the sea' (stella maris) within the Parisian entry is provided by Gringore, who both described and explained his seven pageants in British Library, MS Cotton Vespasian B II, a manuscript dedicated and presented to the new queen that subsequently returned with her to England in the spring of 1515 after Louis died. ${ }^{87}$ Gringore's descriptions are accompanied in the manuscript by paintings illustrative of

84 U. Chevalier, Repertorium hymnologicum: Catalogue des chants, hymnes, proses, sequences, tropes en usage de l'église latine depuis les origines jusqu'à nos jours (Louvain, 1892-1912), iii, no. 25737, iv, no. 36836.

85 Gringore, Les Entrées royales, p. 132.

86 Giry-Deloison,“'“Une hacquenée”, p. 157.

87 British Library, Cotton MS Vespasian B II has been edited and discussed in C. R. Baskervill, Pierre Gringore's Pageants for the Entry of Mary Tudor into Paris: An Unpublished Manuscript (Chicago, 1934). Baskervill states that the MS returned to England with Mary on p. x. 
each pageant. Of particular interest here is his description of the significance of the sixth pageant at the Châtelet, which includes five 'personnaiges' (Phebus, Diana, Bon Accord, Minerva and Stella Maris), and contains contemporary depictions of both Louis (Phebus) and Mary (Stella Maris) (see Figure 8) ${ }^{88}$ Gringore explains that Phebus the sun represents the king, Diana the moon is France, Minerva is Wisdom, and Stella Maris is Mary of England, Queen of France. He goes on to note that even as the moon takes its light from the sun, France is ennobled and illuminated by the powerful virtues, authority and virtuous works of the king. He concludes that it can be seen through the intervention of Minerva that Stella Maris takes her light from Phebus and Diana, and that the coming of the king's good and virtuous spouse has made Good Accord between the two countries.

Since the tableaux vivants of the Boulogne and the Parisian entries draw close parallels between Mary Tudor and the Virgin Mary and refer to the new queen as 'friend', rose and star, it seems possible that Dulcis amica dei was inserted on the second decorated folio not only to serve as a prayer to the Blessed Virgin on behalf of an unidentified person ('mei') who was near death, but also to ask the new queen (her 'godchild') to remember and to pray for that person. The placement of this motet on one of only two fully decorated pages in the manuscript, directly opposite her portrait, suggests that the person offering the prayer was of some importance, and might well have been the person who commissioned MS 1760. The original shield of St Michael at the bottom of the page indicates that this person was a member of the French nobility. The most obvious person for whom such a prayer would have been requested is the aged man who apparently commissioned both this manuscript and the Hours of Mary of England (Lyon, BM MS 1558) as wedding gifts for his new queen, King Louis himself.

When Mary arrived in France Louis was only a few months beyond the official period of mourning for Anne of Brittany, and her death demonstrably affected him deeply. When she died, he knew (as did many other observers throughout Europe) that he, too, would not be long for this world. Prioris's motet, though not composed specifically for MS 1760, was very well known; indeed, along with Févin’s Sancta Trinitas it was one of the most widely disseminated and copied pieces composed by a royal court musician during the late fifteenth and early sixteenth centuries. Since it was no secret at the court that during the final years of his life the king was in very poor health (in fact, he was barely well enough to go to Abbeville to meet Mary, and she spent virtually all of the eighty-two days of their marriage

88 The following summary is drawn from the French original in Baskervill, Pierre Gringore's Pageants, p. 12. 
taking care of her sickly spouse, who was largely bedridden), the relevance of this text to Louis's situation in late 1514 would have been obvious to anyone associated with musicmaking at the royal court, including the court musician(s) who organised and planned MS 1760. It is unlikely that Louis would have objected to the inclusion of this motet in his wedding gift, which clearly was intended for private use, since it called on the Virgin Mary and apparently also his new wife to remember him at the hour of his death. The decoration of fol. II $^{\mathrm{r}}$ supports this interpretation of the text, since it is dominated by blue forget-me-not flowers and strawberry plants (the latter symbolising purity and fecundity). At the bottom of the page is a dragonfly (libellule, also called aiguille-serpent), which in French folklore was a symbol of death. But it is sitting on top of a hazelnut (noisetier), which folk traditions held to be efficacious in killing serpents. ${ }^{89}$ The upper right margin of fol. $\mathrm{II}^{\mathrm{r}}$ contains a flowering chickpea plant, recognised since the Middle Ages as one of the most potent natural male aphrodisiacs. $^{90}$

\section{THE CREATOR OF THE TABULA}

Given the considerable evidence of pre-compositional planning in MS 1760 and the manuscript's almost certain origin at the French royal court during the second decade of the sixteenth century, reconsideration of the attributions in the tabula provides evidence suggestive of the identity of the anonymous musician who planned the manuscript on behalf of Louis XII. The tabula provides composer attributions for fifty-six of its fifty-seven pieces. The only attribution not given in the tabula is for Il mest advis que je voy perrichon, a work ascribed within the manuscript to 'Hyllayre', now generally believed to refer to the master of the chapelle du roi in 1510-15, Hilaire Bernonneau. Archival evidence discovered by Christelle Cazaux in the compte listing expenses for Louis XII's funeral and obsequies in January 1515, Archives Nationales MS KK 89, indicates that Bernonneau directed the court's group of five choirboys in early 1515, a position traditionally held by the overall music director of the royal chapel. ${ }^{91}$ She did not notice, however, that the manuscript entry pertaining to the choirboys in KK 89 identifies them not simply as chapel singers, but rather as 'cinq petitz chantres de la maison et chappelle dud feu sr' (five little singers of the maison and the chapelle of the aforementioned deceased lord). ${ }^{92}$ Since Louis and his successors

89 Sébillot, Le Folk-lore de France, iii, pp. 304, 278.

90 See http://notchesblog.com/2014/06/05/what-was-the-ultimate-medieval-aphrodisiac/.

91 Cazaux, La Musique, p. 343.

92 The entry in AN KK 89, fols. 59 ${ }^{\text {r-v }}$ reads as follows: 'A lui pour avoir faict de __ aulnes de fin drap noir cinq robbes et cinq chapperons de dueil pour cinq des petitz chantres de la maison et 
maintained two separate groups of adult singers, a large group in the royal chapel to perform sacred music at Mass and the Offices, and a small group in the royal household (the maison du roi) who performed secular music in the king's chambers, the entry in AN KK 89 indicates that in 1515 the court's choirboys sang not only the sacred repertory of the court with the royal chapel singers, but also secular music with the household musicians. The choirboys' dual responsibilities can leave little doubt that their director was equally wellversed in the court's sacred and secular musical repertories, knowledge necessary for someone charged to create a manuscript such as MS 1760. That Bernonneau planned the manuscript and created the tabula is suggested by his position as the music director of the king's chapel and the fact that the only piece without a composer attribution is his own chanson. That he enjoyed the confidence of the French monarchs and the sort of intimacy required to create a document as personal as MS 1760 is indicated by his status at the court ${ }^{93}$ and appointment after Louis's death as a personal body servant for Francis I, a valet de chambre, a position shared during the early years of Francis's reign by two other distinguished musicians, Bernonneau's successor as the musical director of the chapelle du roi Antoine de Longueval, and Antoine Divitis. ${ }^{94}$

THE RESOLUTION AND SIGNIFICANCE OF GASCONGNE’S CANON

chappelle dud feu sr estans soubz maistre Hillaire, qui est pour chacun robbe et chapperon au feur de xx st vallent la somme de c sts.'

93 During the late fifteenth and early sixteenth centuries music directors of the chapelle du roi such as Ockeghem, Longueval and Bernonneau bore several titles, one of which was 'conseiller du roi'.

94 A newly uncovered archival notice indicating that Hilaire Bernonneau died in 1524 recently has come to light. Documents in the Archives Départementales of Vienne, série G (clergé séculier) note that 'Hilaire Béronneau' served as the Dean of the cathedral of St-Pierre-le-Grand in Poitiers from 1511 until his death in 1524. The catalogue entry for these records reads as follows: '15111524.- - Hilaire Béronneau. Le Gallia ne l'a pas connu. La date de sa mort, arrivée en 1524, nous est donnée dans une réintégrande en la possession du doyenné de l’Église de Poitiers pour $\mathbf{M}^{\text {re }}$ Bertrand de Kneringhen, faite par le lieutenant général de la sénéchaussée de Poitiers, du 21 mars 1537 (Arch. de la Vienne, G 181 et 189)' (Inventaire-sommaire des archives départementales antérieures à 1790. Vienne. Archives ecclésiastiques, Série G. - nos. 1 à 1343, ed. L. Rédet et A. Richard. Tome premier (Poitiers, 1883], i, pp. viii-ix). This information neatly dovetails with documents discovered in the Vatican archives by Richard Sherr concerning Bernonneau's acquisition of this benefice (Sherr, 'The Membership of the Chapels', p. 64). The Inventairesommaire notes that Bernonneau was preceded as Dean by two other individuals with close ties to the French royal court, Olivier de Pontbriant, who worked as the Dean in Poitiers from 1456 to 1505 and concurrently served as the treasurer of the Sainte-Chapelle du Palais in Paris starting in 1476, and Aymar Gouffier, brother of Guillaume Gouffier (c. 1488-1525), one of the most influential figures at the French royal court in the early years of Francis I's reign, who held the deanship from 1505 to 1511. 
The theory that MS 1760 was ordered by Louis as a wedding gift for Mary Tudor and originally contained a portrait of her sheds light upon the extraordinary size and unusual musical content of the unique motet just below the portrait, Gascongne's canon Ista est speciosa (see Appendix III). As was noted above, Gascongne composed a number of occasional motets during the middle of the second decade of the sixteenth century for Louis and Francis I, and his heavy representation in MS 1760 strongly suggests that he was a favourite of the former monarch after Antoine de Févin's death and that he played a significant role in the preparation of the Pepys manuscript. There is reason to suspect that Gascongne’s canon was commissioned specifically for MS 1760, to judge from the following factors: (1) its small footprint, which barely fits within the allocated space on fol. $\mathrm{I}^{\mathrm{v}}$; (2) its highly restricted dissemination; (3) its text, whose choice reflected not only the Marian traditions associated with the liturgical text 'Ista est speciosa', but also its use in the liturgy for the processional entry of a queen into a city and its appearance at the beginning of the first entry in which Mary Tudor participated after her arrival on English soil; and (4) physical evidence from MS 1760 suggesting that the single canonic voice of the motet was copied into the manuscript very late in its preparation, possibly even after the major decorations and the owner-portrait had been added to fol. Iv .

This motet is preceded by the canonic inscription in Latin that puzzled Burney's friend Thomas Twining, which reads 'Canon. Epithoniza bina tempora pausando vel econverso.' The term 'epithoniza' appears to derive from the Greek preposition 'epi’ (above or higher) and a verbal form of the Latin 'tonus'. 95 The inscription may be translated 'Canon. Perform at a higher tone after waiting two tempora, or vice versa'. The musical realisation of the canon is greatly aided by the presence of eleven signs of congruence, each consisting of three dots and a tail. Such signs appear in all three canonic motets in MS 1760 to show where each canonic voice concludes. ${ }^{96}$ The eleven signs of congruence in Ista est speciosa indicate that the work is a twelve-voice canon. No other composition in Pepys 1760 has more than five voices, and over half the pieces in the manuscript are set for only three voices. Canonic works such as Ista est speciosa in which each voice part enters one step

${ }^{95}$ Similar terminology may be found as part of the canonic instructions for two movements of Compère's Missa L'homme armé in VatC 234, the Sanctus ('Tempora bina pausa. post has uni postonisa') and the Agnus Dei III ('Fuga unius temporis in epithono'). The former phrase indicates a canon at the lower $2^{\text {nd }}$, the latter a canon at the upper $2^{\text {nd }}$. See the facsimile edition of VatC 234, fols. 227 and 231 ${ }^{\mathrm{v}}$ in Renaissance Music Sources in Facsimile, vol. 22 (New York \& London, 1987).

${ }^{96}$ In the only other source of Gascongne's canon, RegB 220-2, there are two sets of signs. The signs above the melody indicate where the successive voices enter, and the signs below the melody show where each part ends. 
higher than the preceding part have been described as examples of 'stacked canon' by Alan Gosman, a term also adopted by David Burn in his analytical study of Ista est speciosa and a canonic mass setting by Forestier. ${ }^{97}$ Following the research of Willem Elders, Burn suggested that the use of twelve voices in Gascongne's motet was inspired by the reference in Revelation 12:1-6 of a woman 'clothed with the sun, with the moon under her feet and a crown of twelve stars on her head', imagery that commonly referred to the Virgin Mary in contemporaneous iconography. ${ }^{98}$ It may be suggested additionally that both the rising fifth that starts the canonic melody and the steady ascent of the tessitura as the successive voices enter could have been inspired by the text of the previous motet in MS 1760, Févin’s Quae est ista quae ascendit, which refers to an object steadily rising like a column of smoke from the desert.

The pitch content of Gascongne's canon poses problems of interpretation, as was noted by Burn. ${ }^{99}$ It is clear that the successive comes were not meant to provide 'real' answers to the $d u x$, since a 'real' answer in the second entrance would require an $F\{\operatorname{sh}\}$ on bar $4_{2}$, which then would force the third voice to enter outside of the G Dorian scale indicated by the key signature. Two features in the canonic melody are especially noteworthy: (1) it contains three perfect melodic intervals, an opening perfect fifth (bb. 1-2), an octave (bb. 67) and a perfect fourth (bb. 8-9); and (2) the melody returns to its beginning pitch before leaping an octave (cf. bb. 1-7). If one applies these principles to the successive entries of the canonic melody, it rapidly becomes clear that the sixth canonic entrance in T.1 must be on $E\{f l\}$ and not $E\{n a\}$ (b. 11), to judge from the leap of a perfect fourth from $B\{f l\}$ to $E\{f l\}$ in bars $10-11$ of $\mathrm{B} .2$ and the octave leap of $\mathrm{B}\{\mathrm{fl}\}$ to $\mathrm{B}\{\mathrm{fl}\}$ in B.1. To avoid diminished and augmented melodic intervals all $\mathrm{E}$ pitches must be read as $\mathrm{E}\{\mathrm{fl}\}$ from bar 10 . At bars 15-16 the $E\{f l\}_{S}$ in A.2, A.3, T.1 and T.2 require that the ninth voice, A.1, must enter on $A\{f l\}$. From bar 16 all pitches of $\mathrm{E}$ and A must be flatted in order to avoid augmented and diminished melodic intervals. In bars 22-3 the octave in A.1 and the perfect fourth in A.2 require that the twelfth canonic entrance in Tr.1 must be on $\mathrm{D}\{\mathrm{fl}\}$, and other $\mathrm{D}\{\mathrm{fl}\}$ s occur on the downbeat of bar 23 in Tr.3, A.2, T.1, T.2, T.3, B.2 and B.3. The leap of a fourth in B.2 in bars $24-5$ requires the introduction of $\mathrm{G}\{\mathrm{fl}\}$ on the downbeat of bar 25 , a reading that is replicated with G\{ft $\}$ pitches in Tr.1, Tr.2, Tr.3, A.1 and A.2. In bars 25-6 the G $\{\mathrm{fl}\} \mathrm{s}$ in B.2,

97 See A. Gosman, 'Stacked Canon and Renaissance Compositional Procedure', Journal of Music Theory, 41 (1997), pp. 289-317; and D. Burn, 'Further Observations on Stacked Canon and Renaissance Compositional Procedure: Gascongne’s Ista est speciosa and Forestier’s Missa L'homme armé', Journal of Music Theory, 45 (2001), pp. 73-118.

98 W. Elders, Symbolic Scores: Studies in the Music of the Renaissance (Leiden, 1994), pp. 171-9.

99 Burn, 'Further Observations', pp. 80-1. 
T.3, A.2, A.1, Tr.3, Tr.2 and Tr.1 demand that all C pitches in bar 26 must be read as C $\{\mathrm{fl}\}$. The modulatory cycle into the soft side of the hexachordal system continues in bar 27 with the introduction of $\mathrm{F}\{\mathrm{fl}\}$ in B.3, B.1, T.3, T.1, A.3, A.2, Tr.3 and Tr.1. The leap in bars 28-9 in $\mathrm{T} .3$ from $\mathrm{F}\{\mathrm{fl}\}$ to $\mathrm{B}$ requires that the latter pitch be read as $\mathrm{B}\{2 \mathrm{fl}\}$ to avoid a melodic tritone, and B\{2fl $\}$ s also appear in bar 29 in Tr.1, Tr.2 and Tr.3. In bar 30 the B\{2fl $\}$ in T.3 requires a following $\mathrm{E}\{2 \mathrm{fl}\}$ (descending perfect fifth), which is matched in Tr.1. The E $\{2 \mathrm{fl}\}$ at the end of bar 30 in Tr.1 demands a leap to $A\{2 f l\}$ on the downbeat of bar 31, a pitch that is replicated throughout the texture. In bars 32-3 leaps of a descending fifth from A $\{2 \mathrm{fl}\}$ (B.2) and of an ascending fourth from $A\{2 \mathrm{fl}\}$ (T.1) require $\mathrm{D}\{2 \mathrm{fl}\}$ s on the downbeat of bar 32. The entire motet comes to rest upon a euphonious sonority built over $\mathrm{G}\{2 \mathrm{fl}\}$ in bars $33-$ 4.

Both the consistency of the structure of Ista est speciosa and its single, simple compositional principle, that direct melodic fourths, fifths, and octaves must always be perfect intervals, provide the ideal sonorous analogue to the view of Mary Tudor as expressed in the royal entries as the 'filloeule' of the Blessed Virgin. It perfectly matches Elders's and Burn's insight that the use of twelve voices might well be a reference to the Woman in the book of Revelation who was 'clothed with the sun, with the moon under her feet and a crown of twelve stars on her head', a scriptural passage that commonly was interpreted as a reference to the Virgin Mary. Both in voicing and in contrapuntal structure, therefore, Gascongne's motet embodies the perfection of the Blessed Virgin even as it praises the beauty of her 'godchild' Mary Tudor. As David Burn has noted (though his edition does not attempt to eliminate all tritones), 'it is not too farfetched to see Ista est speciosa as an earthly reflection of the music of Heaven. The vision imagines a perfect system free from the tyranny of the diabolus in musica, even if we must wait until we are in the actual presence of the Angelic choir before we can really experience what that may mean. ${ }^{, 100}$ In a broader sense, the motet thus fits smoothly into the overall ethos of MS 1760 , which appears to have been created as a gift to a woman referred to as a 'Paradise' by contemporary commentators; one that celebrates the joining of England and France, an event compared to the original perfection of the Garden of Eden in Mary's entries; and whose musical contents appear to have been selected to provide a numerological embodiment of divine perfection through the use of exactly three canons, twenty-seven $(3 \times 3 \times 3)$ motets, and twenty-seven $(3 \times 3 \times 3)$ secular works.

Although the harmonic language of Ista est speciosa may be surprising at first glance, it

${ }^{100}$ Ibid., p. 93. 
is not incompatible with contemporaneous composition. Gascongne's motet does not exceed the tonal palette of either the anonymous double canon $a 4$ on Salve radix in LonBLR $11 \mathrm{E}$. xi, a source prepared and offered to Henry VIII in the spring of 1516 to celebrate his reunion with his two sisters Margaret and Mary, ${ }^{101}$ nor that of Willaert's famous chromatic duo Quid non ebrietas (What cannot be accomplished through drinking), a piece that reportedly mystified and frustrated the papal singers of Pope Leo X (r. 1513-21) when they attempted it, according to Gioseffo Zarlino’s Dimostrationi harmoniche. It cannot be accidental that all three of these experimental pieces were written within a few years of each other. Indeed, if Willaert truly visited the papal court of Pope Leo X after having studied both law and musical composition in Paris, the latter with Jean Mouton, as Zarlino states, it may well be that his idea for a chromatic motet derived from his knowledge of Gascongne’s canon. Moreover, Ista est speciosa may well have been known in England prior to the spring of 1516, since there is good reason to suppose that the manuscript was transferred from France to England one year earlier.

\section{TRANSFERRAL OF MS 1760 TO ENGLAND}

Mary's ownership of the Pepys manuscript provides a mechanism that readily explains how and when it migrated to England and found its way into the royal library of Henry VIII. After Louis XII died on 1 January 1515, less than three months after the marriage in Abbeville, Mary was required to stay at the Hôtel de Cluny in Paris as dowager queen for some time in order to see whether or not she was pregnant with the next heir to the French throne. ${ }^{102}$ She was sure enough that she was not pregnant in early January that she could inform François d'Angoulême that he could go ahead with his coronation as the next French king, which he did with unseemly haste on 25 January 1515. Mary, however, could not return to England yet, since extensive negotiations had to take place between the new French king and English representatives over the ownership of the precious jewels Mary had been given by Louis during their eighty-two-day marriage, as well as discussions about the return

101 Theodor Dumitrescu has made a convincing case that LonBLR $11 \mathrm{E}$. xi was prepared and offered to Henry VIII in the spring of 1516 to celebrate his reunion with his two sisters Margaret and Mary (Dumitrescu, The Early Tudor Court and International Musical Relations (Aldershot, 2007), pp. 129-47). In 'Constructing a Canonic Pitch Spiral: The Case of Salve radix', in K. Schiltz and B. J. Blackburn (eds.), Canons and Canonic Techniques, 14th-16th Centuries: Theory, Practice, and Reception History (Leuven, 2007), pp. 141-70, Dumitrescu not only argues persuasively that Salve radix spirals from $\mathrm{G}$ to $\mathrm{G}\{\mathrm{fl}\}$, but also provides contemporaneous theoretical justification for such a reading.

102 The following account of Mary's actions in early 1515 derives largely from Richardson, Mary Tudor, pp. 127-85. See also Perry, The Sisters of Henry VIII, pp. 108-14, and Sadlack, The French Queen’s Letters, pp. 91-118. 
of Tournai to the French, and what to do about the million gold crowns due to England from Mary's wedding contract. The leader of the English negotiating team was Charles Brandon, Duke of Suffolk, whom Mary had known since her childhood and had admired even before leaving England for France in October 1514. While waiting for the negotiations to be completed, Mary determined that she would marry Brandon rather than let her brother shop her off to another European ruler for political ends. This course of action must have seemed reasonable to her, since letters from the queen to her brother in early 1515 indicate that she believed that he had promised her when she left Dover for France that if she married Louis 'for the advancement of the said peace and for the furtherance of your causes' she would be permitted to marry whomever she wished after Louis's death. ${ }^{103}$ Henry probably was aware that Mary admired Brandon before she left England, and Brandon demonstrably spoke with the king about the possibility that he might marry his sister before he went to France in late January 1515, although subsequent events leave no doubt that Henry expected Brandon to wait for his approval. Notwithstanding Henry’s wishes, Mary and Brandon were secretly married in front of a handful of witnesses in the Cluny chapel in late February. After this secret marriage, which Henry's adviser Cardinal Wolsey learned about in a letter written to him by Brandon on 5 March, both Brandon and Mary quickly wrote to Henry in attempts to avert his wrath over what he could only have viewed as broken promises and obvious contravention of his will.

Since both Mary and Brandon earnestly desired to return to England, Cardinal Wolsey and Henry shamelessly exploited the couple's weak position to extract every bit of financial gain that they could out of the situation. In early March Mary secretly sent her brother the French crown jewels she had received from Louis, including the famous Mirror of Naples and eighteen pearls worth 10,000 crowns, largesse that strongly irked Francis I, who viewed the jewels as a French national possession to be held by her queen and not as a personal gift to Mary. On 9 March Mary signed over 'all such plate and vessel of clean gold as the late King Loys of France, the XIIth of that name, gave unto me the said Mary his wife; and also, by these presents I do freely give unto my said brother, King of England, the choice of such special jewels as my said late husband King of France gave me'. ${ }^{104}$ Since the new French king Francis I was delighted that Mary was marrying an Englishman, and was not being used as a pawn of Henry's foreign policy, in a treaty of 5 April he agreed to pay the arrears of the

103 Richardson, Mary Tudor, pp. 146-7.

${ }^{104}$ Letters and Papers, Foreign and Domestic, of the Reign of Henry VIII, Preserved in the Public Record Office, the British Museum, and Elsewhere in England, vol. 2, pt. 1, ed. J.S. Brewer (London, 1864), p. 78. 
1 million gold crowns due from Louis XII to Henry, and on 14 April reimbursed Mary 200,000 crowns of her dowry ('dote') just before she left Paris for Calais, where she and Brandon had to wait for two more weeks before being allowed to return to England. ${ }^{105}$ Mary's final note to Henry from Calais, in which she begs his goodwill and states that she will wait until she hears from him, essentially signs over her entire life and fortune to her brother to regain his goodwill, including her dowry, all gold plate and jewels that she received from Louis, and 'such securities for repayment of her dowry as he shall see fit'. ${ }^{106}$ Because of groundless fears that Mary might have become pregnant by Brandon, with Henry's approval they enacted a more public marriage ceremony in Paris in front of a bishop at the end of March. To ensure that the English people would recognise the legitimacy of Mary's children, the couple also married a third time at Greenwich on Sunday, 13 May. ${ }^{107}$

The most probable time for the redecoration and repurposing of MS 1760 was March and early April 1515, between the revelation of the secret marriage and Mary’s departure from Paris on 16 April. The overpainting of the Saint Michael shields was necessary in a gift offered by a French queen to an English king because the gift came from a woman, not a man, and a woman could not use the heraldry of the military order of Saint Michael. Mary's options were to overpaint the shields of Saint Michael with gold paint (which would have left gaps in the decoration of fols. $\mathrm{I}^{\mathrm{v}}$ and $\mathrm{II}^{\mathrm{l}}$ ), to overpaint them with her own French arms (unlikely, since she already had eschewed her position as queen of France by marrying Charles Brandon), or to overpaint them with heraldry appropriate for Henry, the shields of Saint George. The modification of the colour of the garter from blue to white in the English royal arms above the tabula may be a simple error by a French painter, as noted earlier, but it may also reflect an attempt by Mary to personalise her gift to her brother by changing the garter colour to the colour white, which she herself recently had worn during the forty days of her official period of mourning, while reminding him of her contrition for marrying Charles Brandon without his permission. The lack of a loop in the Garter simply reflects space and design considerations on fol. $2^{\mathrm{v}}$, since a downward loop would have forced the artist to reduce the overall size of the royal emblem to avoid going beyond the bottom of the frame and onto the remainder of the Latin dedication to the Virgin Mary. The overpainting of Mary's own portrait with Henry's probably would have taken somewhat longer than the shields or royal arms, but not excessively so, given the presence of Jean Perréal at the royal court, who not only is the most likely source of the original miniature in MS 1760, but also

\footnotetext{
${ }^{105}$ Ibid., p. 102.

${ }^{106}$ Ibid., pp. 75-6, 96. See also Richardson, Mary Tudor, pp. 176-85.

${ }^{107}$ Richardson, Mary Tudor, pp. 173-4, 190; Letters and Papers, Foreign and Domestic, pp. 87-8.
} 
apparently had very recently painted both Louis XII and a youthful Henry VIII, the latter almost certainly sans the beard he wore in his iconic depictions by Hans Holbein the Younger (see Figure 9). ${ }^{108}$

\section{ANALYSIS OF PRIOR THEORIES OF THE CREATION OF MS 1760}

The new evidence and analysis presented above makes possible a re-evaluation of prior theories concerning why and when Pepys 1760 was created. There are four theories of the manuscript's creation: (1) MS 1760 was ‘written for' Henry VIII and his wife Catherine of

${ }^{108}$ On this image of Louis XII taken from the British Royal Collection (www.royalcollection.org.uk/collection/403431/louis-xii-king-of-france-1462-1515, (c) Her Majesty Queen Elizabeth II 2016), see Dupont, 'A Portrait of Louis XII Attributed to Jean Perréal'. The image provided for Mary Tudor is a painting hanging in the National Gallery in London under the name 'The Magdalen' that has a nineteenth-century label on the back identifying Mary Tudor as the sitter (see www.nationalgallery.org.uk/paintings/netherlandish-themagdalen). The attribution to Perréal is given in the explanatory notes to the Exhibition Illustrative of Early English Portraiture (London, 1909), p. 104, which were written by Lionel Cust, Director of the British National Portrait Gallery in 1909 (the image is taken from this source). The image of a youthful but jowly Henry VIII around 1525-6 was painted by Lucas Horenbout, a Flemish painter who worked at the English royal court from 1525 until his death in 1544. It may be seen at 222.royalcollection.org.uk/collection/420010/henry-viii-1491-1547, (C) her Majesty Queen Elizabeth II 2016. Notwithstanding the 1959 Sotheby's sale of a portrait of Henry VIII 'as a young man' attributed to Perréal (see above, n. 76), no painting of Henry VIII can be definitively identified as the work of Perréal. That any portrait of Henry prior to 1519 almost certainly was beardless was demonstrated by the late John Fletcher, who used dendrochronological (tree-ring) evidence to show that a series of early portraits of Henry painted on oak boards, all but one of which show him beardless, must date from the second or early third decade of the sixteenth century. The beard in the single bearded early portrait of Henry, the Anglesey Abbey portrait, can be shown to have been a later addition through the use of x-ray analysis (see Tudor-Craig, 'Iconography of the Painting', pp. 307-15, and especially the X-ray image of the Anglesey painting on p. 311). In addition to the articles and books on Henry's portraiture cited by Tudor-Craig see also Lionel Cust, 'Notes on Pictures in the Royal Collections-XXXIX: On the Portraits of King Henry VIII', Burlington Magazine, 31 (1917), pp. 217-24, and Frederick Hepburn, 'The Portraiture of Arthur, Prince of Wales', Journal of the British Archaelogical Association, 148 (1995), pp. 163-4 and n. 68. The portrait of Henry as a young man that emerges from these studies differs shockingly from the conventional modern view of the monarch, which derives largely from several portraits painted by Hans Holbein the Younger in the 1530s and 1540s that show a large, overweight, and bearded monarch. As TudorCraig notes (n. 65), Henry rapidly gained weight between c. 1512 and 1515-20. The image of a skinny, beardless youth with underhung jaw depicted in the youthful portrait of the king now located in the Berger Collection of the Denver Art Museum (http://www.bergercollection.org/?id=5\&artwork_id=69), though clearly the same individual appearing in the early portraits of Henry analysed by Fletcher and Tudor-Craig, is hardly recognisable as the person painted by Holbein. Tradition holds that Henry first grew a beard in about 1519 under the influence of Francis I. 
Aragon upon the birth of their daughter Mary on 18 February 1516; ${ }^{109}$ (2) it was originally 'intended' for Louis XII or both Louis and Anne of Brittany, but was repurposed as a diplomatic gift to Henry VIII on short notice upon the death of Henry VII on 22 April 1509 and the coronation of Henry VIII in June of the same year; ${ }^{110}$ (3) it was commissioned by Louis XII to be given as a wedding gift to Mary Tudor in late 1514 and subsequently was regifted to Henry VIII when Mary returned to England after Louis’s death in January of 1515; ${ }^{111}$ and (4) it was created for Louis or Anne of Brittany around 1512, but was repurposed to be offered as a wedding gift to Mary Tudor in late 1514, before being re-gifted a second time to Henry VIII. ${ }^{112}$

As noted previously, since the overpainting on the opening folios precludes the possibility that Henry VIII was the original recipient of the Pepys manuscript, he could not have commissioned MS 1760 for either his own use or to be given as a gift, nor could its careful planning have been inspired by a commission from a member of the French royal court to serve as a present to him. Thus if it was given to Henry in 1516 to celebrate the birth of his daughter Mary, as suggested by Lowinsky’s article, this gift resulted from re-gifting, and not original creation. All of the evidence adduced in support of this theory (that the coat of arms above the tabula was that of a king and not a Prince of Wales; that the luxuriousness of the manuscript made it well suited to be a gift for a king or queen; that MS 1760 might well have provided a retrospective anthology of the works of Févin after his death; that Févin's On a mal dit chanson cycle would 'make excellent sense in a manuscript dedicated to a happy young couple’; and that the heavy representation of Marian motets in MS 1760 was appropriate in a gift offered to celebrate the birth of Henry’s daughter Mary), ${ }^{113}$ also could be used to support the theory that the manuscript was created for Mary Tudor as a wedding gift. Indeed, it could be argued that the Févin chanson cycle, which pertains to a couple mal marié and not a 'happy young couple', actually is more appropriate for Mary and Louis than for Henry and Catherine. Although the 1516 theory as originally presented does not recognise the evidence linking MS 1760 to Mary Tudor's royal entries, it is not completely incompatible with the Mary Tudor theory, provided that the gift to Henry is viewed as a re-gifting after Louis XII died and Mary returned to England. But the probability

\footnotetext{
${ }^{109}$ Lowinsky, ‘A Music Book for Anne Boleyn’, pp. 162-4.

${ }^{110}$ Litterick, 'The Manuscript Royal 20.A.XVI', pp. 46-57, and Fenlon, Cambridge Music Manuscripts, p. 125.

${ }^{111}$ Brobeck and Dobbins; see above, n. 48.

112 Robinson, 'Le Manuscrit', pp. 54-69.

${ }^{113}$ Lowinsky, ‘A Music Book for Anne Boleyn’, pp. 162-4.
} 
that MS 1760 was gifted to Henry by Mary to signify her penitence in May 1515, rather than as a celebratory gift from the French royal court in 1516 is indicated by two pieces of evidence: (1) since the overpainted portrait indicates that Henry could not have commissioned MS 1760 but could only have received it as a gift, it would not have been necessary to overpaint the shields of Saint Michael unless it came as a gift from a woman; (2) the presence of a white Garter in the royal arms above the tabula makes perfect sense in a gift offered by Mary to her brother, since in early 1515 she demonstrably did repent her rash decision to secretly marry Charles Brandon and had just finished a period of forty days in which she was forced to wear white as a sign of mourning. If, on the other hand, the manuscript was given to Henry as a celebratory gift in 1516, one is forced to assume that the French royal court artists either were careless in their depiction of heraldry intended to honour a powerful rival who was very well known to the court, or simply didn't know any better, theses that are difficult to defend given the existence of other illuminated manuscripts from the Continent that do correctly render English royal heraldry.

One can scarcely overstate the importance of Louise Litterick's research for all subsequent studies of MS 1760, the present study included. She was the first to link the decorations of the Pepys manuscript to the atelier of Jean Bourdichon, to recognise the importance of the overpainting, and to identify the overpainted shields as those of Saint Michael. She was the first to suggest that Samuel Pepys might have mistakenly assigned MS 1760 to the reign of Henry VII because of confusion about the status of Henry when the miniature portrait on fol. $\mathrm{I}^{\mathrm{v}}$ was painted, a suggestion that now can be emphatically corroborated by dendrochronological studies of early paintings of the king that reveal that his appearance changed shockingly between 1513 and the 1530s. Moreover, she recognised that the incorporation of Févin's Adiutorium nostrum could have significance for the dating of the manuscript, and suggested that the presence of this motet 'would indicate that it must have been made before the death of Anne of Brittany in January 1514', a conclusion later adopted by Iain Fenlon and Alexander Robinson. Since England and France were more or less continuously at war between 1511 and January 1514, she concluded that the manuscript 'was converted into a gift for its English royal recipient on rather short notice, following an unexpected event. The most likely circumstance would appear to be the death of Henry VII on 22 April 1509 and the subsequent coronation of Henry VIII in June’' ${ }^{114}$

Clearly the specific date suggested by Litterick for the gifting of MS 1760 to the English royal court is incompatible with the evidence presented in this essay, since her theory places

${ }^{114}$ Litterick, ‘The Manuscript Royal 20.A.XVI’, pp. 54 and 55. 
the manuscript in England five years before Mary Tudor's royal entries in France, events that provided most of the imagery and symbolism that appear to have guided Hilaire Bernonneau or whoever planned MS 1760. The following list identifies a number of the most significant ways in which the new evidence adduced in this essay either casts doubt upon or conflicts with the 1509 theory:

$<$ half-line space $>$

1. Although the 1509 theory recognises as a hypothetical possibility that the portrait of Henry VIII could have been painted over an earlier portrait, it does not emphasise the point that the meticulous preparation of MS 1760 argues strongly that this type of overpainting actually did occur, and that there was an earlier portrait of a member of the French royal court under Henry's missing miniature. Thus, although the theory states that MS 1760 was 'intended' for Louis, it tacitly assumes that the first time MS 1760 was presented to anyone was to the English court in 1509.

2. The 1509 theory does not recognise that the original portrait on fol. $\mathrm{I}^{\mathrm{v}}$ of MS 1760 must have been a woman, not a man, because it does not identify the close association between the text 'Ista est speciosa' and Marian religious observance; consider the plain meaning of the text; recognise that it was the first song sung at the Processional Entry of an Empress or Queen in the Roman Catholic liturgy around the time the Pepys manuscript was created; or note the significance of the placement of Gascongne's twelve-voice canon directly below the missing portrait, the only piece on one of only two highly decorated folios in the manuscript.

3. The 1509 theory does not take into account that both the text 'Ista est speciosa' and the preceding text in MS 1760, 'Quae est ista quae ascendit', were spoken directly to Mary Tudor at the beginning of her first royal entry on French soil while she stood in front of a boat decorated with lilies and roses.

4. It does not recognise that the principal decoration on fol. $I^{\mathrm{v}}$ of MS 1760, the lily and the rose, almost certainly was not incorporated into the manuscript by chance, but rather symbolised the joining of France and England in the marriage of Louis and Mary, and that this imagery was one of the principal symbols employed in Mary's four royal entries, including her first entry at Boulogne. No references to roses occur in either of the two royal entries Anne of Brittany made into Paris after her coronations in 1492 and 1504, nor do roses appear in the royal entry made in 1517 by Claude, Anne's daughter and the first wife of King Francis I. Indeed, the imagery and symbols used in Anne’s and Claude’s royal entries are 
completely different from those employed for Mary in 1514, and do not praise the new queens for their freshness, beauty, and fecundity, but rather are highly impersonal, as has been argued in detail by the historian Cynthia J. Brown. ${ }^{115}$ As in the Grandes heures d'Anne de Bretagne, the dominant heraldic symbol in the entries of Anne and Claude was not the rose, but rather the ermine tail (martre, martin), since both women were simultaneously Queen of France and Duchess of Brittany. The difference in heraldic symbolism between the 1514 entry and Claude’s in 1517 may be exemplified by the differing decorations and texts spoken as part of the tableaux vivants at the Fontaine de Ponceau. On both occasions the tableau vivant had texts praising the joining of the king and the queen. But in 1514 the fountain was decorated with a lily and rose intermingled, and the accompanying poetry was completely devoted to the union of the rose and lily. In 1517, the symbols were an ermine of Brittany (Claude) and the salamander of Francis I, and the poetry praised 'ce beau jardin francoys'. ${ }^{116}$ In contrast to the thematic use of the Annunciation in the 1514 entry, the tableau vivant at the Porte aux paintres in the 1504 entry placed Queen Anne in the midst of five biblical female figures named Anne or Hannah, at least two of whom had difficulty conceiving children, but finally bore them through the gift of God. ${ }^{117}$

5. The 1509 theory fails to recognise that not only the lily and the rose, but also virtually every other painted image on fols. $\mathrm{I}^{\mathrm{v}}$ and $\mathrm{II}^{\mathrm{r}}$ of MS 1760 had symbolic significance for Mary and Louis, an interpretation corroborated by the fact that every image on these folios also appears on a single decorated folio added in 1514 to Lyon, BM MS 1558, a manuscript demonstrably offered to Mary Tudor by Louis XII as a wedding gift.

6. It does not recognise that the selection of Dulcis amica dei for the second decorated folio, a text that has no obvious relation to Anne's and Louis's relationship, could have been motivated by the unique situation faced by Mary and Louis at the end of 1514, and that the opening words of the motet closely reproduce the textual imagery applied to Mary Tudor in her royal entries.

${ }^{115}$ Detailed discussion of royal entries by French queens from Isabelle of Bavaria (1389) through to Claude of France (1517) with original texts of the entries appears in Pierre Gringore, Les Entrées royales à Paris de Marie d'Angleterre (1514) et Claude de France (1517), ed. C. J. Brown (Geneva, 2005), passim. See pp. 195-214 (Anne in 1492); 215-56 (Anne in 1504); 127-56 and 257-72 (Mary in 1514); and 157-94 and 273-327 (Claude in 1517). See also C. J. Brown, The Queen's Library: Image-Making at the Court of Anne of Brittany (Philadelphia, 2011), pp. 19-27, 41-62.

${ }^{116}$ Brown, The Queen's Library, p. 48.

${ }^{117}$ Gringore, Les Entrées royales, pp. 246-7. 
7. The 1509 theory posits that Antoine de Févin was still alive at the time MS 1760 was created, but forces one to assume that Mathieu Gascongne was composing heavily for the crown at least two to three years prior to the earliest evidence associating him with the French royal court, and almost a decade prior to the earliest archival document that refers to him as a singer in the chapelle du roi.

8. The 1509 theory does not explain the significance of the most extraordinary work in MS 1760, Gascongne’s twelve-voice canon Ista est speciosa, which appears directly under the missing portrait; that it contains three to four times as many voices as virtually every other piece in the manuscript; that its text appears to pay tribute to Mary Tudor's widely heralded beauty; that its voicing and contrapuntal structure embody the perfection of the Virgin Mary and by extension her 'godchild' Mary Tudor; and that it can be linked to two similar chromatic works that go far afield harmonically and were apparently composed within a year or two of each other, one written for Henry VIII, and the other composed by a pupil of the French royal court composer Jean Mouton.

9. Finally, the 1509 theory does not place the careful planning and preparation of MS 1760 within a broader context of pre-compositional intent since it does not recognise that not only Ista est speciosa, but in fact the entire content of the Pepys manuscript, including the exact numbers of canons, motets, and chansons that were included, probably was carefully planned to honour Mary Tudor along with her namesake the Virgin Mary, and to symbolise the perfection that the French people attributed to the Blessed Virgin, her godchild Mary, and the peaceful joining of France and England after a period of active warfare, a condition that contemporaries described as a 'paradise'.

$<$ half-line space $>$

It is true that the theory that MS 1760 was created by Louis XII in 1514 for Mary Tudor closely matches the evidence presented in this article, since it was initially developed in recognition of a significant portion of this evidence, but there is one aspect of the content of MS 1760 that plays an important role in points (2) and (4) that remains to be explained within the context of a wedding gift to Mary Tudor: why would a motet narrowly associated with Anne of Brittany's attempts to bear a male heir such as Adiutorium nostrum, as well as three Lamentation settings and Sufficiebat nobis, be included in a manuscript intended as a wedding gift? Since the Mary Tudor theory is based upon codicological, decorative, and textual evidence indicating that MS 1760 was created over a short period of time around the time of her royal entries and wedding, and was not the result of a re-gifting of an earlier 
manuscript prepared for Anne or Louis, it must necessarily presuppose that Anne was deceased at the time the manuscript was created.

Given the evidence presented by Dulcis amica dei suggesting that Louis XII had a measure of personal involvement in the preparation of MS 1760 as a wedding gift, it may be suggested that the inclusion of Adiutorium nostrum, the Lamentations settings, Sufficiebat nobis, and occasional ermine-tail continuation signs could have stemmed from the king's desire to recall the sacrifices made by his previous queen (whom he demonstrably cherished) and his residual sorrow at her death and the death of the majority of the children they produced together. That the original meaning of the text of Adiutorium nostrum was meant to be modified when the motet was included in MS 1760 is indicated by a textual variant appearing only in the Pepys manuscript. All other sources of Adiutorium nostrum present the third line as 'Orat, plorat, exorat, Anna sibi’ (Anna prays, laments and obtains help for herself). MS 1760, however, casts the third verb in the optative subjunctive, 'Orat, plorat, et exoret Anna sibi' (Anna prays, laments, and may she obtain help for herself). The complete text in MS 1760 may be translated as follows:

$<$ EXT $>$ Adiutorium nostrum in nomine domini. Quis non confitebitur tibi? Orat plorat et exoret Anna sibi. Te orantes deprecamur fac ut cito adiuvemur per tuam clementiam. O Regnate tam beate, Ludovicus clamat ad te. Audi queso vocem nostram.

Our help is in the name of the Lord. Who will not confess to you? Anna prays, laments, and may she obtain help for herself. Praying, we beseech you to bring it about that we may be quickly helped through your mercy. O René so blessed, Louis cries to you: hear, I beg, our voice. ${ }^{118}<$ EXT/>

The textual variant indicates that Anne still required help at the time MS 1760 was prepared. Since she was deceased in October 1514, the help could not be to produce more children, but rather must refer to the desire of all deceased Catholics to obtain remission of time in Purgatory, a doctrine very much in force in the early sixteenth century. This interpretation of the variant uncouples the motet from the specific pilgrimages Anne made to the chapel of St René in Angers in 1508 and following, and places it within the needs of the French court and people in 1514: to obtain divine favour for their recently deceased and much-beloved former queen, and to implore St René's aid for the most pressing problem facing Louis XII and the French nation in the fall of 1514 , how to obtain a male heir to ensure the continuation of the

${ }^{118}$ I am grateful to Dr. Cynthia White of the University of Arizona for pointing out the nuances of this construction and assisting me with this translation. 
Orléans cadet branch of the ruling Valois family.

Evidence suggesting that prayers such as this were offered by courtiers on behalf of Anne well after her demise may be drawn from an anonymous twenty-line poem appearing on the first folio of British Library, MS Cotton Vespasian B II. As noted previously, the primary content of this manuscript (which was prepared by Pierre Gringore as a gift to Queen Mary Tudor) is the author's description and explanation of the theatrical productions he created for Mary's entry into Paris on 6 November 1514. The first folio of the manuscript, however, additionally provides a poetic épigramme written in the first person singular in which Anne of Brittany posthumously describes her reign and calls upon the French people to pray to God that he 'mecte ma poure âme en celéste lumyère' (place my poor soul in heavenly light). The poetry comprises lines 11-30 of the final poem in Pierre Choque’s Commémoration de la mort de madame Anne .. . Royne de France, the most detailed description of the ceremonies surrounding Anne's funeral services. As Cynthia J. Brown has noted, numerous copies of the Commémoration were prepared by Choque for Anne's female relatives and other female members of the French nobility, including one made for Louise of Savoy that refers to the latter as the 'mother of the king' (Francis I), a reference dating its preparation from January 1515 or later. ${ }^{119}$

As noted previously, the physical structure of MS 1760 provides no indications that the manuscript was created in France for Louis or Anne and then repurposed as a wedding gift to Mary Tudor, as suggested by Alexander Robinson, ${ }^{120}$ and virtually all of the problems posed by the new evidence for the 1509 theory apply with equal force to the double re-gifting hypothesis. Moreover, evidence used to support the latter theory that is drawn from the texts of pieces appearing in MS 1760, and in particular motets dealing with birth and three chansons that allude to a lack of money (Faulte d'argent, Celle qui and J'ay veu), applies to Mary Tudor as well or better than to Anne. Finally, an important component of this theory, that the missing portrait actually portrayed Louis and not Henry VIII, seems insupportable in the light of Burney's confirmation of the description given in Bernard's 1697 catalogue and the evidence presented above concerning Ista est speciosa.

\section{CONCLUSIONS}

\footnotetext{
119 The poem in Vespasian B II is transcribed in Gringore, Les Entrées royales, p. 104, n. 248. Choque's Commémoration is discussed in detail and the final epigram is transcribed and translated in Brown, The Queen's Library, pp. 279-305.

${ }^{120}$ Robinson, 'Le Manuscrit', pp. 54-69.
} 
It now is possible to sketch a somewhat more complete history of MS 1760. Like the decorated book of hours Lyon, BM MS 1558, known as the Hours of Mary of England, MS 1760 was prepared at the behest of Louis XII as a wedding gift for Mary Tudor sometime in mid- to late 1514. Unlike Mary’s book of hours, however, MS 1760 was newly created. Its rapid creation over a period of a few months was facilitated by the fact that it contained relatively little new music, since the great majority of its pieces were drawn from the standard musical repertory performed at the court of Louis XII. The decoration of MS 1760 suggests that it was prepared either at the royal court in Paris or possibly in Tours. ${ }^{121}$ If the latter was its place of origin, it might lend some credence to the identification of Maître Jean Boitel, vicar of the church of Tours in 1503, as the composer of the canonic Ave Maria that opens the manuscript. MS 1760 was very carefully planned in advance, with the musical contents being laid out in conformity with the order and foliation laid down in the current tabula. The manuscript contents were planned to fit within twelve quaternions of parchment, of which exactly eleven were to be devoted to music, with empty ruled folios at the beginning of the first music quaternion and at the end of the last quaternion. The twelfth quaternion of parchment was to be used for (1) three unruled folios at the beginning of the manuscript, including the front flyleaf and the tabula; (2) two folios at the end, the first of which was ruled to approximate the appearance of the beginning of the manuscript and the second the rear flyleaf; (3) one folio at the end that was clipped off and is no longer a part of the manuscript; and (4) seventh and eighth folios that either served as the original covers or provided the paste-downs that attached the body of the manuscript to the gold-cloth covers. With the exception of fol. $\mathrm{I}^{\mathrm{v}}$, the gatherings devoted to four-voice music (gatherings $1-5$ and 11) were uniformly ruled, with space being left at the beginning of the first and fifth staves on each page for either an illuminated majuscule or an illuminated depiction of a flower. Gatherings 6-10, which are entirely devoted to motets and chansons $a$ 3, omit staves and the fifth stave blank initial space on verso pages. The illuminated majuscules and flowers, which were painted either by the court painter Jean Bourdichon or a member of his atelier, were consistently executed on every folio where there is music. After the opening illuminated folios, the music was disposed in such a way that every piece begins on the verso side of the opening designated by the tabula foliation. The music was the first item to be copied (with the exception of Gascongne’s canon Ista est speciosa, which was added very late), and it appears to have been copied into the manuscript sequentially from beginning to end. The music was followed by the texts. Several small errors in the manuscript suggest that the

${ }^{121}$ Frank Dobbins suggested to me in 2007 that he thought MS 1760 might have been created in Blois. See above, n. 48. 
music and texts were added prior to the addition of the red foliation, which appears both on the current tabula and on the top right corner of each recto page. The composer attributions in the body of the manuscript and the illuminations seemingly were added after the foliation.

After an introductory section on the two opening illuminated folios consisting of three canonic motets and Dulcis amica dei, the remainder of the music was symmetrically laid out in four sections: (1) four-voice motets; (2) three-voice motets; (3) three-voice chansons; and (4) four- and five-voice secular songs. Because the first three-voice motet, Févin’s $O$ preclara stella maris, required more space than was anticipated by the musician who organised the music in MS 1760 and determined how much manuscript space to allot to each piece (very probably the royal chapelmaster Hilaire Bernonneau, d. 1524), works after $O$ preclara had to begin one folio later than was originally planned. This led to the introduction of two folios numbered XXXIX, and also meant that one extra folio had to be ruled and placed after the final piece, Prioris's Consommo, in order to provide a match for the blank ruled folio at the beginning of the manuscript.

The manuscript's contents were carefully planned to match the themes and symbolism that were used in the four entries that greeted Mary to France as well as to convey personal messages from the king and/or royal court to the new queen. MS 1760 opens with the angelic salutation 'Hail Mary', followed by settings of the Latin texts spoken on 2 October 1514 at the beginning of the first royal entry that greeted Mary Tudor upon her arrival on French soil. The linking of the Virgin Mary and Mary Tudor through their names, their beauty and youthful innocence, and their status as the bringer of peace and the potential mother of a king was frequently reiterated in the four royal entries that Mary participated in during the months of October and early November 1514. Mathieu Gascongne must have been intimately involved in the creation of MS 1760, since not only did he contribute more works than any other composer save the king's recently deceased favourite Antoine de Févin, but also he provided a motet, Ista est speciosa, that was designed to serve as a caption for a miniature portrait of the intended recipient of the manuscript, Mary Tudor. This miniature probably was painted by the king’s portrait painter Jean Perréal, who had painted the princess in England only a matter of weeks prior to the completion of MS 1760, or possibly by another royal court miniaturist who worked from Perréal’s portrait. The crowding visible in the lower right corner of this motet strongly suggests that it was added very late in the compilation of the manuscript, after the illumination on fol. $\mathrm{I}^{\mathrm{v}}$ was complete, and conceivably even after the miniature portrait was added. Almost certainly Gascongne was commissioned by Bernonneau to compose this motet for inclusion at this point in the manuscript, to judge from its unusual scope and contrapuntal structure (a twelve-voice canon 
that both honours the Virgin Mary and embodies the ideal of perfection) and its text (the liturgical text sung during the processional entrance of queens during the late fifteenth and early sixteenth centuries). The decoration of roses and lilies on fol. $\mathrm{I}^{\mathrm{v}}$ mirrors the decorations Mary saw at her first entrée, which took place at Boulogne, and also observes the floral metaphor of the joining of lily and rose that was one of the main themes linking Mary's royal entrées. The last motet on the opening illuminated folios, Prioris's Dulcis amica dei, was given prominent placement on the final fully decorated folio because its text called on the Virgin Mary and her 'godchild' Mary Tudor to pray for the latter's new husband Louis XII, who had commissioned the creation of MS 1760 as a wedding gift. This interpretation of the textual and musical content of fols. $\mathrm{I}^{\mathrm{v}}$ and $\mathrm{II}^{\mathrm{r}}$ is strongly supported by the particular flora and fauna chosen to appear on these pages, each of which possessed well-defined meanings in French folk culture that were relevant either to the young bride Mary or her aged betrothed, and all of which also appear on fol. $8^{\mathrm{r}}$ of Lyon, BM MS 1558, a book of hours demonstrably offered as a wedding gift from Louis to Mary and then re-gifted from Mary to her brother Henry VIII.

Most of the other Latin-texted compositions in the manuscript appear to have been selected from readily available court repertory, some of it up to a decade old or older. The selection of motets was largely based upon the congruity of each work's text with the major themes presented in the royal entrées, which included Mary’s youthful beauty, the wish that she be fecund and produce a male heir to the French throne, and the desire for God to bless the union of the two rulers. A notable exception to this rule is provided by a group of five works towards the end of the four-voice Latin section of MS 1760, Adiutorium nostrum, three settings of the Lamentation of Jeremiah, and Richafort's motet Sufficiebat nobis/Mon souvenir my faict mourir. These pieces, like the ermine-tail continuation signs on some folios in gatherings 6-10, apparently were inserted to express the king's continuing regret at the loss of his previous queen Anne of Brittany and the loss in childbirth or infancy of the numerous infants that she bore him. Louis could assume that any personal messages conveyed by the manuscript to his new queen would not be broadcast widely, since MS 1760 was never intended to be used for public performance, although Mary undoubtedly heard these pieces performed individually by the musicians of the royal court; indeed, perhaps she followed along in her music book.

The chansons in the manuscript, the great majority of which are examples of what has been termed 'three-part arrangements', appear to have been chosen to provide Mary with a good selection of her new husband's favourite type of music, although a number of pieces (the opening chanson cycle beginning with On a mal dit and the final two secular pieces, Si 
jeusse Marion and Consommo), may have been included to represent Louis's recognition of the incongruity of his marriage with a young and beautiful princess, his desire to consummate his relationship with her, and his frustration at his age and poor physical condition. With the possible exception of the chansons composed by Gascongne, most of the rest of the manuscript's secular music appears to have been selected from the standard repertory performed at the court between c. 1500 and $1514 .{ }^{122}$

The musical content of the manuscript, which comprises three canons, twenty-seven motets and twenty-seven chansons, apparently reflects its planner's intent to mirror the perfection ascribed to the Garden of Eden, the Virgin Mary, and by extension her 'godchild' Mary Tudor, by making the number of each type of music a multiple of three. The same intent explains the use of only perfect melodic fourths, fifths and octaves in the motet providing a caption for Mary Tudor's portrait, Ista est speciosa. Given that the royal entries describe Mary Tudor as stella maris, the desire to symbolise perfection numerically may also explain why Févin's motet $O$ preclara stella maris (a work whose text has obvious parallels with Dulcis amica dei) was placed on fol. XXXIX[I] (39), and one also notes that Ista est speciosa is the third piece in the manuscript. Of course, it is equally possible that these placements were not intended to have any symbolic significance.

Mary did not own MS 1760 for very long. Louis XII died less than three months after the marriage. After his death on 1 January 1515 she was required to stay at the French royal court as dowager queen for several months in order to see whether or not she was pregnant and during the negotiations over financial settlements between the governments of France and England. During this period she determined that she would marry an English nobleman she admired, Charles Brandon. She essentially forced Brandon to marry her secretly in Paris, thus presenting her brother Henry VIII with a fait accompli before he could marry her off a second time to serve the needs of state policy. Because of his anger at her independence (although it was an independence based upon Mary's belief that her brother would honour a promise he made to her before she went to France), Henry, through his adviser Cardinal Wolsey, imposed punitive measures upon her before she was allowed to return to England with her new husband. These included large financial penalties and the turning over of gifts she had received in France. The nature of the modifications to the original French decoration and heraldry strongly suggests that Mary gave MS 1760 to her brother shortly after she

122 The change in the title of Gascongne's final chanson in MS 1760 from 'Sy javoys marion' (tabula) to 'Sy jeusse marion' (actual chanson) may indicate that this piece had not yet been composed at the time the tabula was created. 
returned to England in May 1515, although she did not give her personal book of hours (decorated by Poyet and Bourdichon) to him until much later (1530), just three years before her death. The new miniature portrait, like the original, probably was painted by the French royal court painter Jean Perréal, who painted a portrait of Mary just a matter of weeks before the compilation of MS 1760, is known to have painted portrait miniatures, and also is thought to have painted a portrait of Henry VIII as a young man.

By not later than 1542 MS 1760 had become a part of the Westminster Palace library. It eventually became the property of Anne Stanhope Seymour, wife of Edward Seymour, the Lord Protector of England during the minority of Henry VIII's son Edward VI. She bequeathed a gold-covered book that may well have been MS 1760 to Honora Rogers, the wife of her grandson, at her death in 1587.

The manuscript then disappeared for over a century until it resurfaced in the personal library of Samuel Pepys sometime prior to $1693 .{ }^{123}$ Pepys added a leather spine to MS 1760 in order to make it look like the other volumes in his library, but left the gold cloth covers that graced the book during its period of ownership by Anne Stanhope Seymour. The information Pepys placed on the spine, 'K. Hen.7 / Musick', almost certainly derived not from his knowledge of the history of the manuscript, its musical repertory or its decoration, but simply from his recognition that the major items in the English coat of arms above the tabula - the Cadwallader dragon, the Nevill hound, the Garter, and the royal crown - were a part of the royal arms of King Henry VII, whereas the portrait painted on fol. $\mathrm{I}^{\mathrm{v}}$ was recognisable as a youthful Henry VIII. Since these arms are primarily associated with Henry VII and clearly were meant to represent the king's arms and not those of a Prince of Wales, Pepys logically assumed that the manuscript was created for the English royal court during the reign of Henry VII, but that somehow it had become the personal property of the king's second son. His identification was echoed in 1779 by Charles Burney when he saw the manuscript, and undoubtedly was based upon the same reasoning, even though Burney was much better informed about the music and musicians represented in MS 1760. The portrait of a youthful Henry VIII appears to have been a part of the manuscript as late as 1779, although it is equally possible that Burney’s identification of its subject as Henry VIII was simply based upon conversation with librarians or scholars familiar with the history of the manuscript. These observations complete this sketch of the complicated history of MS 1760, an illuminated music manuscript created at the French royal court in the summer and fall of 1514, passed as a gift to Henry VIII in 1515 and owned by at least two other English owners 
during the sixteenth and seventeenth centuries before being purchased for Samuel Pepys’s library, but originally intended to serve as a music book for Mary Tudor, Queen of France.

University of Arizona

$<$ Appendix I follows here $>$

$<$ Appendix II follows here $>$

\section{APPENDIX III}

Gascongne’s motet Ista est speciosa

Pepys 1760, fol. $\mathrm{I}^{\mathrm{v}}$

Figure 1 Decorative borders by Jean Bourdichon and his school: (a) Grandes heures d'Anne de Bretagne, Paris, BnF lat. 9474, fol. 27r; (b) Pepys 1760, fol. Iv; (c) border of Hours of Mary of England, Lyon, Bibliothèque municipale, MS 1558, fol. $8^{r}$

Figure 2 Shelf numbers on the front paste-down and the front flyleaf of MS 1760

Figure 3 Folios $2^{\mathrm{v}}$ and $3^{\mathrm{r}}$ from the opening section of MS 1760

Figure 4 Depictions of the shield and banner of St Michael: (a) MS 1760, fol. IIv; (b) banner of St Michael, from the Battle of the Spurs (1513); (c) Jean Fouquet, title page of the Statutes of the Order of St Michael

Figure 5 Ultraviolet photography of the opening folios of MS 1760: (a) fol. 4v; (b) front flyleaf recto; (c) fol. $2^{\mathrm{r}}$, the back side of the first page of the tabula (image flipped)

Figure 6 Ruling on fol. $4^{\mathrm{v}}$ and fol. $\mathrm{I}^{\mathrm{v}}$

Figure 7 Miniature portraits on French royal court books of hours: (a) Grandes heures d'Anne de Bretagne, Paris, BnF lat. 9474, fol. 3r; (b) Hours of Louis XII, Los Angeles, John Paul Getty Museum, MS 79a; (c) Hours of Charles VIII, Madrid, Biblioteca Nacional, MS vit.24-1, fol. $13^{\mathrm{v}}$

Figure 8 Depiction of Louis XII (Phebus) and Mary Tudy (Stella Maris); detail from British Library, MS Cotton Vespasian B II. Published by permission of (CThe British Library Board.

Figure 9 Portraits of Louis XII, Mary Tudor (?) and Henry VIII: (a) Louis XII, attr. Jean Perréal (Windsor Castle, The Royal Collection); (b) Mary Tudor (?) (The Magdalen), attr. Jean Perréal; (c) Henry VIII, c. 15256, by Lucas Horenbourt (The Royal Collection) 
Brobeck - 62

Example 1 Gascongne’s motet Ista est speciosa (Pepys 1760, fol. Iv) 


\section{APPENDIX I}

\section{Concordances for pieces in Cambridge, Magdalene College, Pepys MS 1760}

\begin{tabular}{|c|c|c|c|c|}
\hline No. & Fols. & Composition & Attributions (Tabula/MS) & Concordances \\
\hline 1 & $\mathrm{I}^{\mathrm{r}}$ & $\begin{array}{l}\text { [Ave Maria gratia plena] } \\
\text { 'Canon. ...ternas. Totum dat quarta. } \\
\text { pausas hinc quod canis apta. Psalle } \\
\text { breves dyapa[son]. Sed semibreves } \\
\text { dyathessa. O. cane tres partes, } \\
\text { quartam. <C/> psallere debes' }\end{array}$ & Io. Boytel/Io. Boytel & unicum \\
\hline 2 & $\mathrm{I}^{\mathrm{r}}$ & Que est ista que ascendit ( $a$ 4) & A. de fevin/A. de fevin & $\begin{array}{l}1540^{7}, \text { no. } 101 \text {, Antonius Fevin (Quae est ista quae processit) } \\
1545^{7} \text {, no. } 118 \text {, Anto. Fevin (Quae est ista quae processit) }\end{array}$ \\
\hline 3 & $\mathrm{I}^{\mathrm{v}}$ & $\begin{array}{l}\text { Ista est speciosa (a } 12 \text { ) } \\
\text { 'Canon. Epithoniza bina tempora } \\
\text { pausando vel econverso' }\end{array}$ & M. gascongne/M. gascongne & contrafactum: Verbum Domini in RegB B220-2, fol. 87v, Gascongne \\
\hline \multirow[t]{13}{*}{4} & $\mathrm{II}^{\mathrm{r}}$ & Dulcis amica dei (a 3) & Prioris/Prioris & AmiensBM 162, fol. 117v, anon. (a 3) \\
\hline & & & & $\begin{array}{l}\text { CambraiBM 125-8, fol. } 133^{v} \text {, anon. (a } 4 \text {; 'O dulcis amica dei’; 4th } \\
\text { lower, with si placet altus part and written out final repetition) }\end{array}$ \\
\hline & & & & CopKB 1848, p. 413, anon. (a 3) \\
\hline & & & & LonBL 31922, fols. 88v-89, anon. (a 3) \\
\hline & & & & LonBL 35087, fols. 61 -62 , anon. ( a 3) \\
\hline & & & & ParisBNF 2245, fols. 31ㄴ-32, anon. (a 3) \\
\hline & & & & SGallS 462, fol. 1, anon. (a 4) 'Dulcis Maria dei' \\
\hline & & & & SGallS 463, fol. 52, anon. ( $a$ 4) \\
\hline & & & & UppsU 76a, fols. 55ㄴ56, Prioris (a 4) \\
\hline & & & & WashLC L25, fols. 139v-140, anon. (a 3) \\
\hline & & & & [c.1521] $]^{7}$, fol. $16^{\mathrm{v}}$, anon. (tenor only) \\
\hline & & & & $1540^{2}$, no. 1 , anon. (a 3) \\
\hline & & & & $1546^{1}$, no. 1 , anon. (a 3) \\
\hline 5 & $\mathrm{II}^{\mathrm{v}}-\mathrm{IIII}^{\mathrm{r}}$ & Dei genitrix virgo semper Maria (a 4) & prioris/Prioris & unicum \\
\hline \multirow[t]{2}{*}{6} & III $-V^{\mathrm{r}}$ & Verbum bonum et suave ( $a$ 4) & A.de fevin/P. de therache & FlorD 666, fols. $40^{\mathrm{v}}-41$, Therache \\
\hline & & & & LonBLR 8.G.VII, fol. 30v, anon. \\
\hline
\end{tabular}


LonRC 1070, fols. 36-38, anon.

$1519^{1}$, no. 1 , Therache

$1521^{5}$, fols. $6^{\mathrm{v}-7}(\mathrm{~S}), 21^{\mathrm{v}}-22(\mathrm{~T}), 35^{\mathrm{v}}-36(\mathrm{~A}), 51^{\mathrm{v}}-52$ (B), Therache $1526^{2}$, no. 1 , Therache (ATB)

$7 \quad \mathrm{~V}^{\mathrm{v}}-\mathrm{VII}{ }^{\mathrm{r}} \quad$ Suscipe verbum virgo Maria (a 4)

$8 \quad$ VII $^{\mathrm{v}}-\mathrm{IX}^{\mathrm{r}} \quad \mathrm{O}$ admirabile commercium (a 4)

$9 \quad \mathrm{IX}^{\mathrm{v}}-\mathrm{XI}^{\mathrm{r}}$

Quando natus est ( $a$ 4)

$10 \quad \mathrm{XI}^{\mathrm{v}}-\mathrm{XII}{ }^{\mathrm{r}}$

Rubum quem viderat ( $a$ 4)

11 XII - XIII

Germinavit radix Iesse (a 4)

12 XIII $-\mathrm{XV}^{\mathrm{r}}$

Ecce Maria genuit nobis (a 4)

$13 \quad \mathrm{XV}^{\mathrm{v}}-\mathrm{XVI}$

Ave Maria gratia dei (a 4)

$14 \quad \mathrm{XVI}^{\mathrm{v}}-\mathrm{XVII}{ }^{\mathrm{r}}$

Ecce Maria genuit nobis (a 4)

15 XVII $^{\mathrm{v}}-\mathrm{XIX}^{\mathrm{r}}$

Sub tuum presidium ( $a$ 4)

16

$\mathrm{XIX}^{\mathrm{v}}-\mathrm{XXI}^{\mathrm{r}} \quad$ Sancta Trinitas unus Deus $(a$ 4)

17

XXI $^{\mathrm{v}}-\mathrm{XXIII}{ }^{\mathrm{r}} \quad$ Nobilis progenie (a 4)

$18 \mathrm{XXIII}^{\mathrm{v}}$ $\mathrm{XXV}^{\mathrm{r}}$
Bontemps [Louis l’Ormeau] / [no attribution]

Io. des prez/Iosquin des prez

Io. des prez/Io. des pres

des prez/Io. des prez

Io. des prez/Iosquin des pretz

Io. des prez/Iosquin des pretz

Io. Mouton/Io. Mouton

Io. Mouton/Io. Mouton

Brumel/A. Brumel

A. de fevin/A. de fevin

A. de fevin/Anthoine de fevin

fevin/A. de fevin unicum

For concordant sources for the $O$ admirabile commercium cycle see NJE 21, Motets on Non-biblical Texts, Critical Commentary, ed. B. J. Blackburn (Utrecht, 2007), pp. xiv-Xv.

unicum

unicum

FlorBNC II.I.232, fols. 88v-89, anon.

LonRC 1070, fols. 35ㄴ-36, anon.

$[1521]^{6}$, fols. $10^{\mathrm{r}}, 11^{\mathrm{r}}, 10^{\mathrm{v}}, 9^{\mathrm{v}}$, Anton Brumel (index)

For concordant sources see NJE 26, Motets on Texts Pro Diversis

Temporibus et Festis and Miscellaneous Texts, Critical

Commentary, ed. T. Braas (Utrecht, 2013), pp. 59-63

BolSP 38, fols. 9v-10, anon.

PadBC A17, fols. 137ㄴ-38, anon.

1514 ${ }^{1}$, fol. 7 (S), 24 (T), 39ㄴ-40 (A), 55 (B), Antonius de Fevin

$1526^{1}$, no. [8], Ant. de Fevin

Lon BLR 8.G.VII, fols. $4^{\text {v }}-6$, anon. [Henry/Catherine text]

LonRC 1070, fols. 128v-130, anon.

OxfBLL a.8, fols. 2-3 , anon. [Margareta text]

VatP 1976-9, fols. 97v-99, anon.

$1514^{1}$, fol. 13 (S), 29ㄴ-30 (T), 46 (A), 61 (B), Io. Mouton [as 2.p. of Caeleste]

$1526^{1}$, no. [22b], Io. Mouton [as 2.p. of Caeleste] 


\begin{tabular}{|c|c|c|c|c|}
\hline 19 & $\begin{array}{l}\mathrm{XXV}^{\mathrm{v}}- \\
\mathrm{XXVIII}^{\mathrm{r}}\end{array}$ & Aleph. Prima lectio (a 4) & $\begin{array}{l}\text { Ro. de fevin/orig. attrib. 'Ant. } \\
\text { de fevin', overwritten 'Ro. de } \\
\text { fevin' }\end{array}$ & $\begin{array}{l}\text { LeipU 49, fols. } 74 \text { (D \& A), } 63 \text { (T), } 76 \text { (B), Georgius Forster } \\
\text { ('Jherusalem’ only; see note below for } 3^{\text {a }} \text { lectio). } \\
1549^{1} \text {, no. } 29 \text {, N. Fevin } \\
1557^{7} \text {, fols. } 3^{\text {v}}-5 \text {, Fevin }\end{array}$ \\
\hline 20 & $\begin{array}{l}\text { XXVIII } \\
\text { XXXI }^{\mathrm{r}}\end{array}$ & Gimel. $2^{\mathrm{a}}$ lectio ( $a$ 3) & Ro. de fevin/A. de fevin & 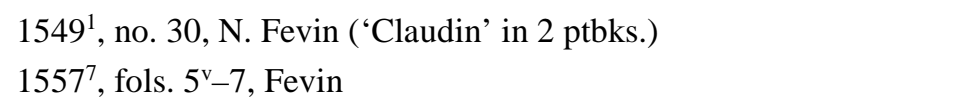 \\
\hline 21 & $\begin{array}{l}\mathrm{XXXI}^{\mathrm{v}}- \\
\mathrm{XXXIII}^{\mathrm{r}}\end{array}$ & Zay. $3^{\text {a }}$ lectio (a 4) & A. de fevin/Anthoine de fevin & 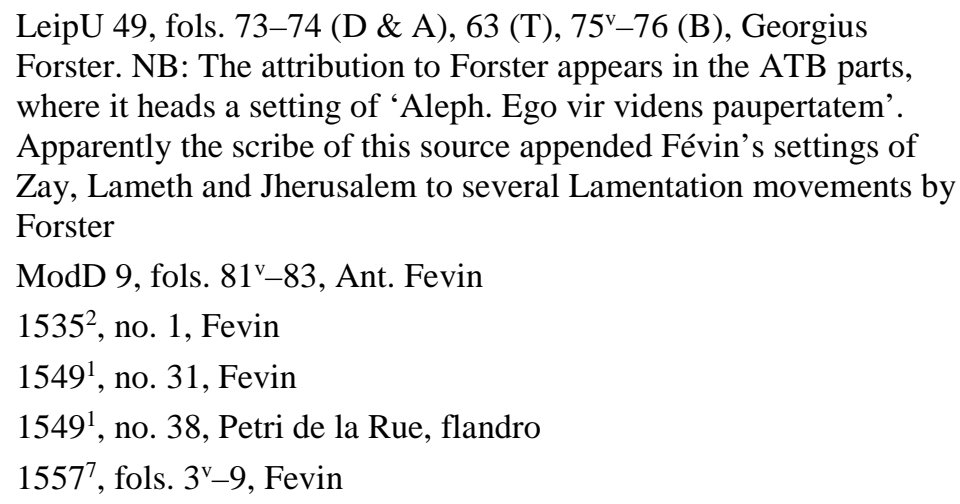 \\
\hline 22 & $\begin{array}{l}\text { XXXIII }{ }^{v}- \\
\text { XXXIIII }^{\mathrm{r}}\end{array}$ & Quam pulchra es ( $a$ 4) & Prioris/Prioris & unicum \\
\hline 23 & $\begin{array}{l}\text { XXXIIII- } \\
\text { XXXVI }^{\mathrm{v}}\end{array}$ & Benedicite Dominus. Amen. (a 4) & Io. Mouton/Io. Mouton & unicum \\
\hline 24 & $\begin{array}{l}\text { XXXVIv- } \\
\text { XXXVIII }^{\mathrm{r}}\end{array}$ & $\begin{array}{l}\text { Sufficiebat nobis paupertas/ } \\
\text { (Mon souvenir my faict morir) (a } 4 \text { ) }\end{array}$ & Richafort/Io. Richafort & 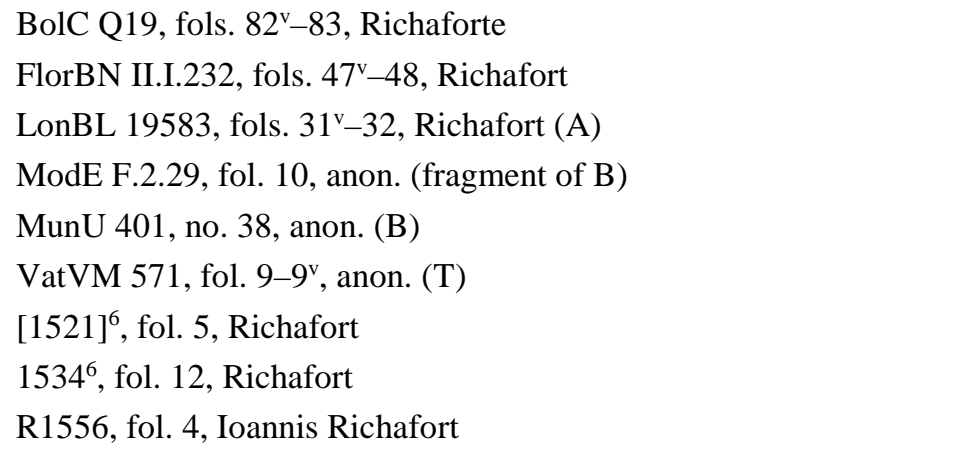 \\
\hline 25 & $\begin{array}{l}\text { XXXVIII"- } \\
\text { XXXIX }^{\mathrm{r}}[2]\end{array}$ & O preclara stella maris ( $a$ 3) & $\begin{array}{l}\text { A. de fevin/Anthoine de fevin } \\
\text { [on second and third openings] }\end{array}$ & CopKB 1848, pp. 92-3, anon. \\
\hline 26 & $\begin{array}{l}\text { XXXIX }{ }^{\mathrm{v}}[2]- \\
\mathrm{XLI}^{\mathrm{r}}\end{array}$ & Dulcis mater dulci nato ( $a$ 3) & M. gascongne/M. gascongne & BrusC 27511, fol. 34, anon. (D only) \\
\hline 27 & $X L I^{v}-X L I I^{r}$ & $\begin{array}{l}\text { Ave Maria gratia dei plena per secula } \\
\left(\begin{array}{l}\text { ( } 3)\end{array}\right.\end{array}$ & prioris/Prioris & unicum \\
\hline
\end{tabular}




\begin{tabular}{|c|c|c|c|c|}
\hline 28 & "XLIIV-XLIII ${ }^{\mathrm{r}}$ & Inclita pura sanctissima virgo (a 3) & fevin/Anthoine de fevin & unicum \\
\hline 29 & $\begin{array}{l}\text { XLIIIV_- } \\
\text { XLVIr }\end{array}$ & Nigra sum sed formosa ( $a$ 3) & M. gascongne/M. gascongne & unicum \\
\hline 30 & $\begin{array}{l}\text { XLVIV_- } \\
\text { XLVII }^{r}\end{array}$ & Parce domine populo tuo (a 3) & obrek/[no attribution $]$ & 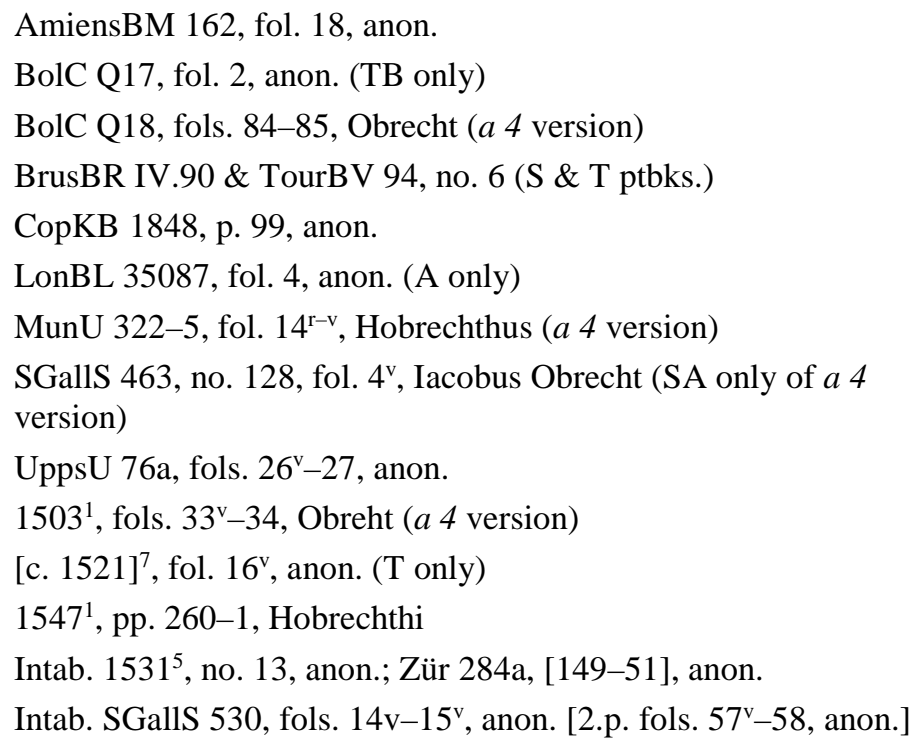 \\
\hline 31 & $\begin{array}{l}\mathrm{XLVII}^{\mathrm{V}}- \\
\mathrm{XLVIII}^{\mathrm{r}}\end{array}$ & On a mal dit de mon amy ( $a$ 3) & fevin/Anthoine de fevin & 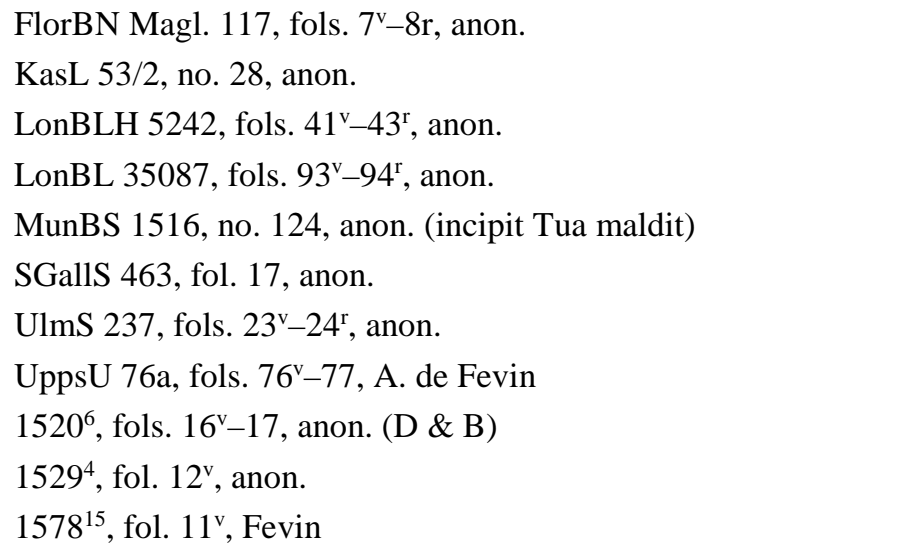 \\
\hline 32 & $\begin{array}{l}\text { XLVIII }^{\mathrm{V}}- \\
\text { XLIX }^{\mathrm{r}}\end{array}$ & Tres doulce dame de bonnayre ( $a$ 3) & A. de fevin/Anthoine de fevin & LonBLH 5242, fols. $13^{\mathrm{v}}-15$, anon. \\
\hline 33 & XLIX ${ }^{\mathrm{v}}-\mathrm{LI}^{\mathrm{r}}$ & Mauditz soient ces maryz jaleux ( $a$ 3) & fevin/Anthoine de fevin & LonBLH 5242, fols. $7^{\mathrm{v}}-9$, anon. \\
\hline 34 & LIV-LII ${ }^{\mathrm{r}}$ & Helas je suys mary ( $a$ 3) & fevin/An. de fevin & FlorBN Magl. 117, fols. (1v)-2, anon. \\
\hline
\end{tabular}


LonBLH 5242, fols. 24v-26, anon.

UppsU 76a, fols. $47^{\mathrm{v}}-48$, anon.

$1541^{2}$, no. 86, Ianequin

$* 1541^{13}$, no. 49 , Ianequin

$* 1543^{23}$, p. 36, Ianequin

35

LII - LIII

Ie le laire puys ( $a$ 3)

36

LIII $-\mathrm{LV}^{\mathrm{r}} \quad$ Chacun maudit ces jaleux ( $a$ 3)

37

LV - LVII $\quad$ En amours na sinon (a 3)

38

LVII ${ }^{\mathrm{v}}-\mathrm{LVIIII}^{\mathrm{r}}$ Petite camusette [...la mort] (a 3) 3)
fevin/Anthoine de fevin

fevin/Anthoine de fevin

fevin/Anthoine de fevin

fevin/Anthoine de fevin

fevin/Anthoine de fevin

fevin/Anthoine de fevin
CopKB 1848, p. 168, anon. (D only, textless)

FlorBN Magl. 117, fols. 6 ${ }^{\mathrm{v}}-7 \mathrm{r}$, anon.

LonBLH 5242, fols. $5^{\vee}-7$, Anth. de feuin

UppsU 76a, fols. 43ㄴ -44 (A. de Fevin)

FlorBN Magl. 117, fols. 2 ${ }^{\mathrm{v}}-4 \mathrm{r}$, anon.

UppsU 76a, fols. 74v-76, anon.

$1520^{6}$, fols. $19^{\mathrm{v}}$ (D), $70^{\mathrm{v}}-71$ (B), anon.

CopKB 1848, pp. 120-1, anon.

TurBN I.27, fol. $46^{\mathrm{v}}$, anon.

UppsU 76a, fols. 33ㄴ -35, A. de fevin

$1520^{6}$, fol. 16 (D), 66 (B), anon.

$1541^{2}$, no. 74 , anon. (incipit only)

LonBL 35087, fols. 87ㄴ8, anon.

MunBS 1516, no. 154, anon.

$1538^{9}$, no. 79 , anon.

$1578^{16}$, fols. 23v-24, Iosquin (SA only)

CopKB 1848, pp. 102-3, anon. (AB only; A = Févin's setting, B is completely different).

CopKB 1873, no. [33], anon. (incipit only)

LonBL 31922, fols. $104^{\mathrm{v}}-5$, anon. (textless)

MusBS 1516, no. 129, anon. (5th lower)

SGallS 463, fol. 18, anon.

$1520^{6}$, fols. 4 (D), $52^{\mathrm{v}}-53$ (B), anon.

[C.1535] ${ }^{14 c}$, no. 51 , anon.

$1538^{9}$, no. 31, anon. (5th lower, textless; later attrib. to 'J'skin')

$1541^{2}$, no. 73 , anon.

$1578^{14}$, fols. $14^{\mathrm{v}}-15$, Fevin (S1, S2 only)

LonBLH 5242, fols. 38v-40, anon.

CopKB 1848, p. 168, anon. (T, textless) 


\begin{tabular}{|c|c|c|c|c|}
\hline 41 & 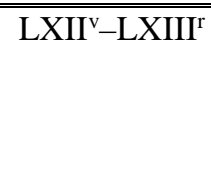 & Iayme bien mon amy ( $a$ 3) & $\begin{array}{l}\text { fevin/N. le petit [written in very } \\
\text { light ink over erased 'Anth. de } \\
\text { fevin', visible in ultraviolet } \\
\text { light] }\end{array}$ & unicum \\
\hline 42 & $\begin{array}{l}\text { LXIII }^{\mathrm{v}}- \\
\text { LXIIII }^{\mathrm{r}}\end{array}$ & Adieu solas tout plaisir ( $a$ 3) & fevin/Anthoine de fevin & $\begin{array}{l}\text { FlorBN Magl. 117, fols. } 14^{\mathrm{v}}-15 \mathrm{r} \text {, anon. } \\
\text { LonBLH 5242, fols. } 20^{\mathrm{v}}-21 \text {, anon. } \\
\text { LonBL 35087, fols. } 53^{\mathrm{v}}-54 \text {, anon. } \\
\text { UppsU 76a, fols. } 35^{\mathrm{v}}-36 \text {, A. de Fevin }\end{array}$ \\
\hline 43 & $\begin{array}{l}\text { LXIIIIV- }^{-} \\
\text {LXV }^{\mathrm{r}}\end{array}$ & $\begin{array}{l}\text { Faulte dargent cest doleur non pareille } \\
\text { (a 3) }\end{array}$ & $\begin{array}{l}\text { fevin/['Anth. de fevin' erased, } \\
\text { but visible in ultraviolet light] }\end{array}$ & unicum \\
\hline 44 & $\begin{array}{l}\text { LXV }_{-}- \\
\text {LXVII }^{\mathrm{r}}\end{array}$ & Iay veu la beaute mamye ( $a$ 3) & fevin/Anthoine de fevin & unicum \\
\hline 45 & $\begin{array}{l}\text { LXVII }^{\mathrm{v}}- \\
\text { LXVIII }^{\mathrm{r}}\end{array}$ & $\begin{array}{l}\text { Il mest advis que je voy perrichon ( } a \\
\text { 3) }\end{array}$ & [no attribution]/hyllayre & $\begin{array}{l}\left.\text { HerdF 9821, fols. [281 }-282^{v}\right] \text {, Antho. Fevin } \\
1520^{6} \text {, fols. } 18^{v} \text { (D), } 69 \text { (B), anon. }\end{array}$ \\
\hline 46 & $\begin{array}{l}\text { LXVIIIV- }^{\text {v }} \\
\text { LXX }^{\mathrm{r}}\end{array}$ & Dieu gard de mal (a 3) & Mouton/Io. Mouton & LonBL 35087, fols. 91-93, anon. \\
\hline 47 & $\begin{array}{l}\mathrm{LXX}^{\mathrm{v}}- \\
\mathrm{LXXII}^{\mathrm{r}}\end{array}$ & Iay mys mon cuer ( $a$ 3) & M. gascongne/M. gascongne & unicum \\
\hline 48 & $\begin{array}{l}\text { LXXIIV- }^{\text {LXXIII }^{\mathrm{r}}}\end{array}$ & Ie voys je viens mon cueur ( $a$ 3) & M. gascongne/M. gascongne & unicum \\
\hline 49 & $\begin{array}{l}\text { LXXIIIV- }^{v}- \\
\text { LXXIIIII }^{r}\end{array}$ & Pastourelle dieu te doint joye ( $a$ 3) & M. gascongne/M. gascongne & unicum \\
\hline 50 & $\begin{array}{l}\text { LXXIIII"- }^{v} \\
\text { LXXVI }^{r}\end{array}$ & Pour avoir faict au gre (a 3) & M. gascongne/M. gascongne & unicum \\
\hline 51 & $\begin{array}{l}\text { LXXVIV }^{v_{-}} \\
\text {LXXVIII }^{\mathrm{r}}\end{array}$ & En ce joly temps gratieux ( $a$ 3) & M. gascongne/M. gascongne & unicum \\
\hline 52 & $\begin{array}{l}\text { LXXVIIIv- }^{v} \\
\text { LXXIX }^{\mathrm{r}}\end{array}$ & Celle qui ma demande ( $a$ 3) & gascongne/M. gascongne & unicum \\
\hline
\end{tabular}



iiiiXXIIIIr
Naymes iames une villaine a 4

Damours ie suys desheritee a 5

Consommo la vita mya a 4
Io. Brunet/Io. Brunet

fevin/A. de fevin

Richafort/Io. Richafort

prioris/Prioris unicum

FlorBN Magl. 117, fols. 78v-79r, anon

UppsU 76b, fols. 133ㄴ-134, anon.

[c. 1535$]^{14 a}$, no. 42 , anon

SGallS 463, no. 204 (SA), Richafort

SGallS 464, fol. 11, Richafort (S)

VienNB Mus. 18746, fols. 25는 26 (T), 29 (S), 31 (A), 29 (B), 26ㄴ 27 (T2), anon.

*Le Roy et Ballard-68 (Eitner 1560c), fol. 36, Richafort

$1572^{2}$, fol. 48, Richafort

unicum

FlorBN Magl. 117, fol. 43v, anon. (a 3)

LonBL 35087, fols. 27늘, anon. (a 3)

ParisBNF 1597, fol. [78], anon. (a 3)

SGallS 462, p. 103, anon. (a 3)

SGallS 463, no. 170, anon. (ST)

WashLC L25, fols. [136ㄴ-37], anon. (a 4)

This table of concordances was made possible by the expertise and scholarly generosity of Herbert Kellman, the director of the Microfilm Archive of Renaissance Sources at the University of Illinois at Champaign-Urbana, and his assistants.

\section{Abbreviations:}

BernC

L. Bernstein, 'La Courone et fleur des chansons a troys: A Mirror of the French Chanson in Italy in the Years between Ottaviano Petrucci and Antonio Gardano', Journal of the American Musicological Society, 26 (1973), pp. 1-68

BernCF

L. Bernstein, 'Cantus Firmus in the French Chanson for Two and Three Voices, 1500-1550' (Ph.D. diss., New York University, 1969)

Braithwaite

J. Braithwaite, 'The Introduction of Franco-Netherlandish Manuscripts to Early Tudor England: The Motet Repertory' (Ph.D. diss., Boston 
University, 1967)

BrownMF

BrownTC

$\mathrm{CRH}$

Couchman

CrawSC

HeartzPC

HewFS

Jeppesen

Lowinsky

Maldeghem

MerrCS

NJE

RokTM

RRMR

ShippC

WexP

H. M. Brown, Music in the French Secular Theater, 1400-1550 (Cambridge, Mass., 1963)

H. M. Brown, 'The Transformation of the Chanson at the End of the Fifteenth Century', IMSR (Ljubljana, 1967), pp. 78-94

U. Chevalier, Repertorium hymnologicum : Catalogue des chants, hymnes, proses, séquences, tropes en usage dans l'église latine depuis les origines jusqu'à nos jours, 6 vols. (Louvain and Brussels, 1892-1921)

J. Couchman, 'The Lorraine Chansonnier: Antoine de Lorraine and the Court of Louis XII’. Musica Disciplina, 34 (1980), pp. 85-157

D. Crawford, Sixteenth-Century Choirbooks in the Archivio Capitolare at Casale Monferrato (Renaissance Manuscript Studies, 2; [s.l.], 1975)

D. Heartz, Preludes, Chansons and Dances for Lute Published by Pierre Attaingnant, Paris (1529-1530) (Neuilly-sur-Seine, 1964).

H. Hewitt, 'Fors seulement and the Cantus Firmus Techniques of the Fifteenth Century', in Essays in Musicology in Honor of Dragan Plamenac on His 70th Birthday (Pittsburgh, Pa., 1969). 91-126

K. Jeppesen, K. Die mehrstimmige Italienische Laude um 1500: Das 2. Laudenbuch des Ottaviano dei Petrucci (1507) in Verbindung mit einer Auswahl mehrstimmiger Lauden aus dem 1. Laudenbuch Petrucci's (1508) und aus verschiedenen gleichzeitigen Manuskripten (Leipzig, 1935) The Medici Codex of 1518: A Choirbook of Motets Dedicated to Lorenzo de' Medici Duke of Urbino, ed. E. Lowinsky (Monuments of Renaissance Music, 3-5; Chicago, 1968)

R.-J. van Maldeghem (ed.), Trésor musical; collection authentique de musique sacrée \& profane des anciens maitres belges, recueillie et transcrite en notation moderne, 6 vols. (Brussels, 1865-93; repr., 1965)

A. T. Merritt, ‘A Chanson Sequence by Fevin', in Essays on Music in Honor of Archibald Thompson Davison by his Associates (Cambridge, Mass., 1957), 91-9.

New Josquin Edition

Treize motets et un prélude pour orgue, parus en 1531 chez Pierre Attaingnant, ed. Y Rokseth (Publications de la Société francaise de musicologie, Première série, t. 5; Paris, 1968)

Recent Researches in the Music of the Renaissance

C. Shipp, 'A Chansonnier of the Dukes of Lorraine: The Paris Manuscript Fonds Français 1597' (Ph.D. diss., North Texas State College, 1960)

R. Wexler, 'The Complete Works of Johannes Prioris’ (Ph.D. diss., New York University, 1974) 


\section{APPENDIX II \\ Mary Tudor’s Entry into Boulogne in September $1514^{1}$}

Text

Entrée solennelle de Marie d'Angleterre seconde femme de Louis XII en la ville de Boulogne le ... septembre 1514.

En l'an de grace mil v cens et xiiij le ${ }^{2}$ jour du moys de septembre, à dix heures devant disner, entra au hable de Boullongne Marie soeur du roy Henry d'Engleterre [VIIIe] et fille du Roy Henry [VIIe], et avec elle grande noblesse de Engleterre, tant princes que princesses, ducz et comtes, ducesses et comtesses et plusieurs prelas d'Eglise; et venoit pour espouser le roy de France Loys xije de ce non, qui estoit vefve de la ducesse de Bretaigne Anne. Incontinent les navires posés à terre audit hable, qui estoient biaulx à veoir, icelle Marie et sa compagnie descendirent à terre dedens ledit hable, auprès de le Burrière; et leur mena on ${ }^{3}$ des chevaulx et hacquenées de c'est ville, pour ce que les navires où estoient leurs chevaulx et bagages ne estoient point venus, pour le rude temps qu'il faisoit, mais vindrent ${ }^{4}$ certains jours après; et

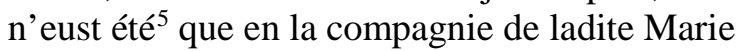
avoit plusieurs bons maronniers, ${ }^{6}$ tant de ceste ville que d'Engleterre, elle n'eust point prins le hable de ceste marée; et dura assés long tamps ledite tempeste, tellement que l'endemain que elle s'en alla en Franche, il fallu bailer les chevaulx de ceste ville, dont notre baiard ${ }^{7} \mathrm{y}$ futt. Quant ladite Marie vint au grand Boullovard sur le Bourcq, messieurs de Notre-Dame, qui estoient partis de leur maison en procession, à tous croix, capes et relicques, passèrent devant
Translation

Solemn Entry of Marie of England, second wife of Louis XII, into the town of Boulogne the ... September 1514.

In the year of grace 1514 the ... day of the month of September, at ten hours before dinner, entered into the harbour of Boulogne Mary, sister of King Henry [VIII] of England and daughter of King Henry [VII], and with her a great part of the nobility of England, both princes and princesses, dukes and counts, duchesses and countesses and many prelates of the church; and she came to marry the King of France Louis XIIth of this name, who was the widower of Anne the duchess of Brittany. Once the ships were anchored in the said harbour, which was a handsome thing to see, the said Mary and her company descended to the ground inside the said harbour, near the Burrière, and they were given horses and carriages of this village, because the ships that had their horses and baggage had not arrived, because of the rough weather, but only came several days later; and if the company of the said Mary had not had numerous good sailors, both from this town and from England, she would never have been able to make the harbour from this tide; and the tempest lasted a long time, so that the next day when she went into France, it was necessary to borrow some horses from the town, of which our bay horse was one. When the said Mary came to the great boulevard on the Bourcq, messieurs of [the church of] Notre-Dame, who had left their house in procession, with the cross, capes, and relics,

1 Text taken from Abbé Haigneré, 'Réception solennelle de Marie d’Angleterre à Boulogne’, Recueil historique du Boulonnais (notices, articles, éphémérides), 1845-93, III (Boulogne-sur-mer, 1899), pp. 715, after original account by Abbé Jacques Leest, abbé de Saint-Vulmer de Boulogne. I have included Haigneré's footnotes where they clarify the meaning of the text.

2 Cette date est restée en blanc.

3 Et on leur mena.

4 Vinrent.

5 Nous dirions aujourd'hui: Et sinon qu'en la compagnie de ladite Marie il y avait, etc.

6 Maronnier est l'ancienne forme du mot marinier, marin.

7 Notre baiard, notre cheval bai, celui qui appartenait à l'abbaye; On trouve ce mot dans Fleuranges: Louis XII arriva à Abbeville sur un grand cheval Bayard qui saultoit. 
notre maison; et nous adoncques ${ }^{8}$ devant notre portail nous jondismes ${ }^{9}$ avecq eulx à tout nos croix, capes et relicques, et encontrasmes ledite Marie ou dit [au] Boullvard; et adoncques Monsieur de Notre-Dame luy bailla à baisier la relicque du lait Notre-Dame, et je luy baillay à baissier le chief de Sainct Wilmer; puys s'en vint ledite Marie jusques au pont, à l'entrée de la ville; et au dessus dudit pont y avoit ung bastiau, dedens lequel avoit une josne fille et deux josnes enfans, abilliés les dits deux josnes enfans en angeles [anges/angelus], et la josne fille comme la Vierge Marie; et avoit ladite jone fille en sa main le present que la ville faisoit à ladite Marie, qui estoit ung chyne ${ }^{10} \mathrm{~d}$ 'argent qui par le col se ouvroit, et dedens luy pendoit ung Coeur d'or pesant LX escus d'or: et estoit ledit batiau bien paint de fleurs de lys et de rozes; et y avoit escript au tour dudit batiau UNG DIEU, UNG ROY, UNE FOY, UNG LOY. Et quant ladite Marie aprocha, ledit batiau s'avalla ${ }^{11}$ par engin, et commença à dire ladite josne fille qui representoit la Vierge Marie ce qui s'ensieut: $\{\#\}$

Que est ista que ascendit per desertum sicut virgula fumi ex aromatibus mirre et thuris? (Canticorum, iii).

$\{\#\}$

Qui est la belle et triumphant pucelle

Plaine d'honneur, de biauté et de sens,

Que nous veons monter comme l'enchens, Pardevant nous, o noble jouvencelle?

$\{\#\}$

Et le premier angle dizoit:

Ista est speciosa inter filias.

$\{\#\}$

C'est de biaulté la rosette flourie,

La souveraine et illustre princesse,

Votre filloeulle appellée Marie,

Par quy la guerre et discord a prins cesse.

Comme de paix vous fustes la deesse,

Fille et espouse au roy celestien;

Pareillement, ceste fleur de noblesse

Est fondement de paix et de leesse ${ }^{12}$

Et chierre espouse au roi très chrestien.

$\{\#\}$

Et le second angle dizoit:

Et circumdabant eam flores rosarum et lilia passed before our house; and we then joined with them before our door with all our crosses, capes and relics, and encountered Mary on the said boulevard; and then Monsieur de Notre-Dame gave her a relic of the milk of Our Lady to kiss, and I gave her to kiss the head of Saint Wilmer; then Mary went up to the bridge at the entry of the town; and above the said bridge there was a boat, within it a young girl and two young children, the two children dressed as angels, and the young girl as the Virgin Mary; and the young girl had in her hand the present that the town made to Mary, which was a silver swan which opened by the neck, and inside there hung a heart of gold valued at 60 gold écus; and the said boat was beautifully painted with fleurs-de-lis and roses; and there was written around the boat ONE GOD, ONE KING, ONE FAITH, ONE LAW. When Mary approached, the ship descended before her by the means of some machinery, and the young girl who represented the Virgin Mary began to say the following:

$\{\#\}$

Que est ista que ascendit per desertum sicut virgule fumi ex aromatibus mire et thuris? (Song of Songs, 3)

$\{\#\}$

Who is the beautiful and triumphant maid

Full of honour, of beauty and sense,

That we see rise like incense

Above us, O noble youth?

$\{\#\}$

And the first angel said:

Ista est speciosa inter filias.

\{\#\}

This is the flowering rose of beauty,

The sovereign and distinguished princess,

Your godchild called Mary,

By whom war and discord have ceased.

As of peace you were the deity,

Daughter and spouse of the celestial king;

Similarly, this flower of nobility

Is the basis of peace and rejoicing

And dear spouse of the most Christian king.

$\{\#\}$

And the second angel said:

Et circumdabant eam flores rosarum et lilia

8 Alors.

9 Nous nous joignimes.

10 Chyne, c'est-à-dire cygne. On croyait avec raison en 1514 avoir le cygne et non l'oie pour emblème.

11 S'avalla par engien, c'est-à-dire descendit par engin; ou à l'aide d'une mécanique. Le patois dit encore dévaller.

12 Leesse ou liesse, joie. Le mariage de Louis XII avec la princesse Marie était la conséquence d’un traité de paix fait avec l’Angleterre. 
convallium. ${ }^{13}$

$\{\#\}$

Comme lassus ${ }^{14}$ vous estes adornée ${ }^{15}$

De biaulx fleurons vertueux et jollis;

Semblablement elle est advironnée

De bruyt d'honneur et de gens anoblis.

Icy veons ${ }^{16}$ rozes et fleurs de lys

Tout d'un accord à sa noble venue;

Loenge à Dieu, le roy de Paradis,

Ou non duquel, Madame, je vous dis

Que vous soyés ycy la bien venue!

$\{\#\}$

Puis ledite josne fille, en presentant le present, dizoit:

$\{\#\}$

Fleur de biaulté, princesse noble et gente,

Prendrés en gré, douce benignité,

Ce petit don, que la communité

De ceste ville humblement vous presente.

$\{\#\}$

Puys entra la dite dame en la ville; et sa compagnie et ceulx de Notre-Dame et nous la convoiasmes, à tout croix etc, jusques à l'église Notre-Dame; et puys, à tout nosdits croix et relicques, retournasmes cheens. ${ }^{17}$

$\{\#\}$

Et Messieurs maieur et eschevins nous

donnerent ledit batiau, pour tant qu'il avoit esté

fait et paint cheens; et que sire Leurens

Framery, prieur de cheens, avoit compose ce qui

cy dessus est escript en rethoricque, et est mis

en notre eglise, tout hault, au bout, en bas

d'ycelle, où lieu où solloient ${ }^{18}$ estre nostres grosses orgues.

$\{\#\}$

Et ne furent point les dits roy et royne ensamble longuement; car au moys de janvier oudit an, mourut ledit roy Loys xije de ce [nom]; et fu roy Franchois, premier de ce nom, qui estoit duc d'Angoulesme, qui avoit espouse dame Claude, fille dudit roy Loys et de ledite Anne ducesse de Bretaigne.

[Terrier de Saint-Wimer de 1505, fol. 152v et 153r, Archives de la ville de Boulogne].

Almanach de Boulogne, 1863. convallium.

$\{\#\}$

As there above, you are adorned

With beautiful flowers virtuous and pretty;

Likewise she is encompassed

With sounds of honour and of noble people.

Here we see roses and fleurs-de-lis

All together for her noble entrance;

Praise to God, the king of Paradise,

Or not of which, Madame, I tell you

That you are here most welcome!

\{\#\}

Then the young girl, in presenting the present, said:

$\{\#\}$

Flower of beauty, princess noble and fair,

Take willingly, sweet blessed one,

This little gift, which the community

Of this town humbly presents to you.

\{\#\}

Then the lady entered into the town; and her company and those of Notre-Dame and ours walked together, with the crosses, etc., up to the church of Notre Dame, and then we returned home with our crosses and relics.

$\{\#\}$

And Messieurs the major and merchants gave us the boat, because it had been built and painted by us; and sir Leurens Framery, our prior, had composed what was here said and written in rhetoric, and it was put in our church, up high, behind, below the place where we normally keep our great organ.

$\{\#\}$

And the said king and queen were not together long; for in the month of January of the said year, the said king Louis XII died; and Francis, first of this name, who was duke of Angoulême, who had married Claude, daughter of Louis and Anne duchess of Brittany, became king.

[Rent roll of Saint-Wilmer (Wulmer) from 1505, fols. $152^{\mathrm{v}}$ and $153^{\mathrm{r}}$, Archives of the town of Boulogne]. Almanach de Boulogne, 1863.

13 Ces paroles sont encore empruntées au Cantique et font une poétique allusion aux lis de France et aux roses des Plantagenets: 'Et les fleurs des roses et les lys des champs entouraient ma bien-aimée.'

14 Lassus, c'est a-dire là sus, ou là haut, au ciel.

15 Adornée, c'est-à-dire ornée.

16 Veons, c'est-à-dire nous voyons.

17 Cheens, c'est-à-dire ici chez nous.

18 Solloient, c'est-à-dire avaient coutume. 
Appendix III Gascongne’s motet Ista est speciosa

"Canon. Epithoniza bina tempora pausando vel econverso. M. gascongne" (Pepys 1760, fol. Iv)

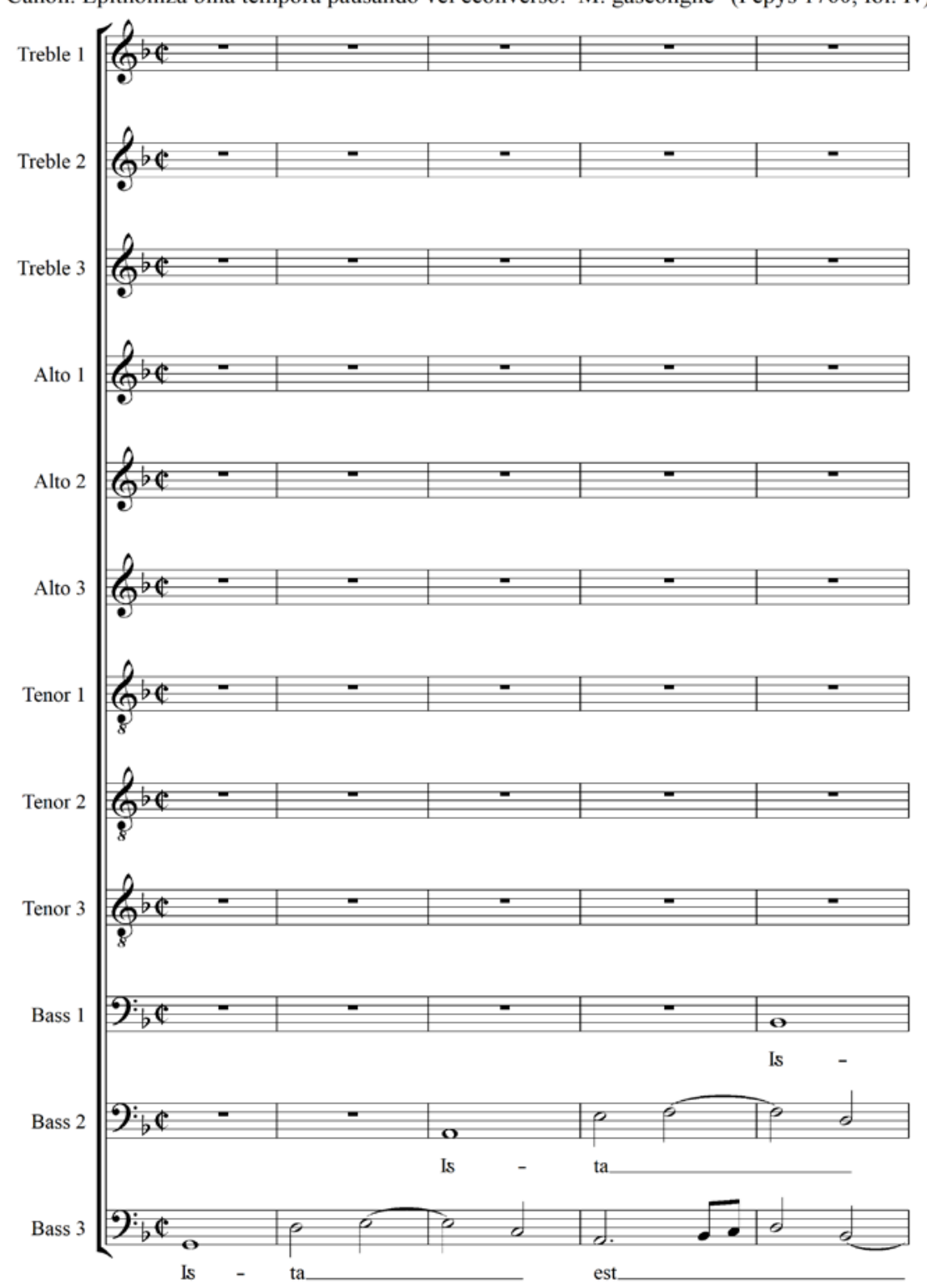

2

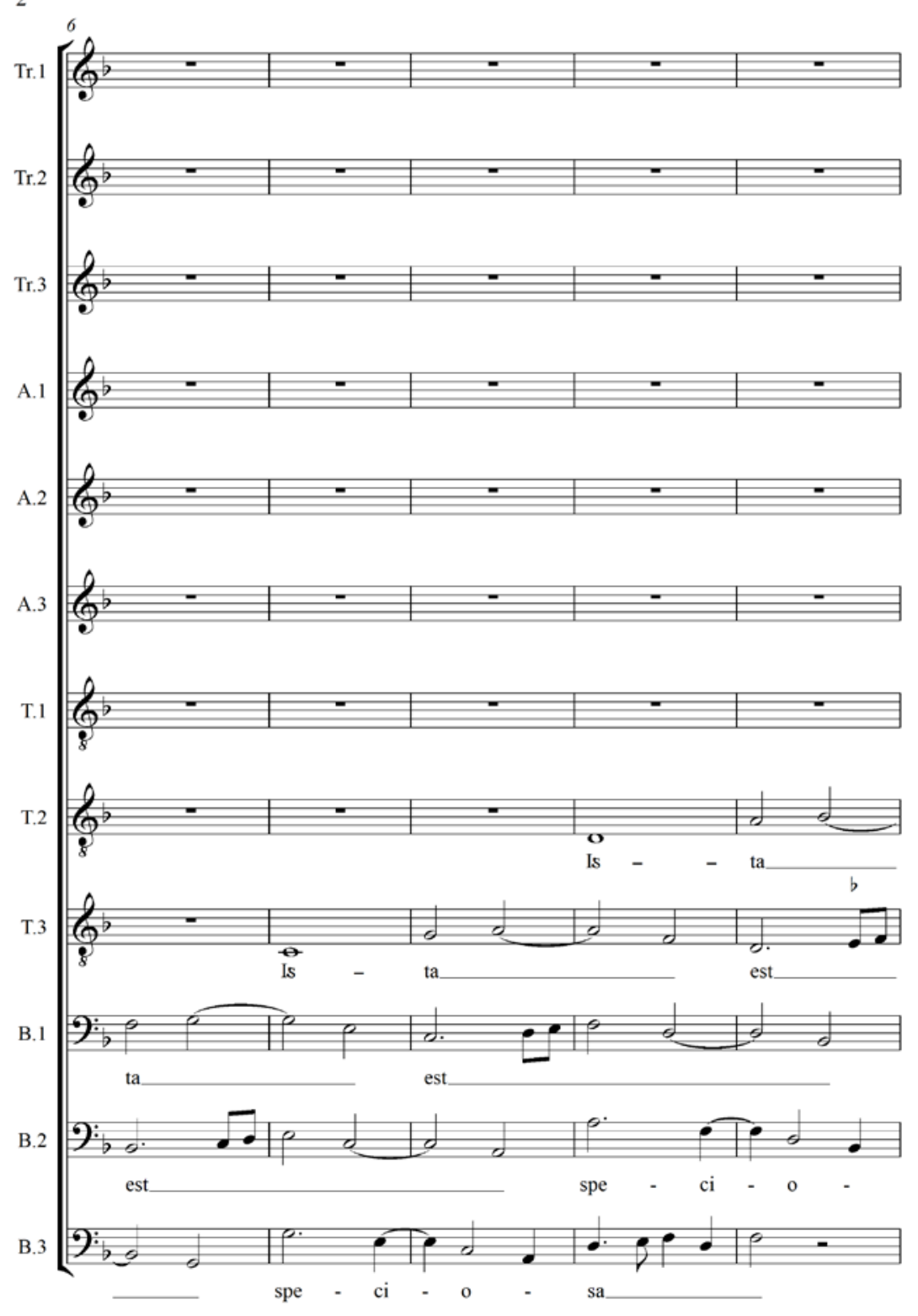



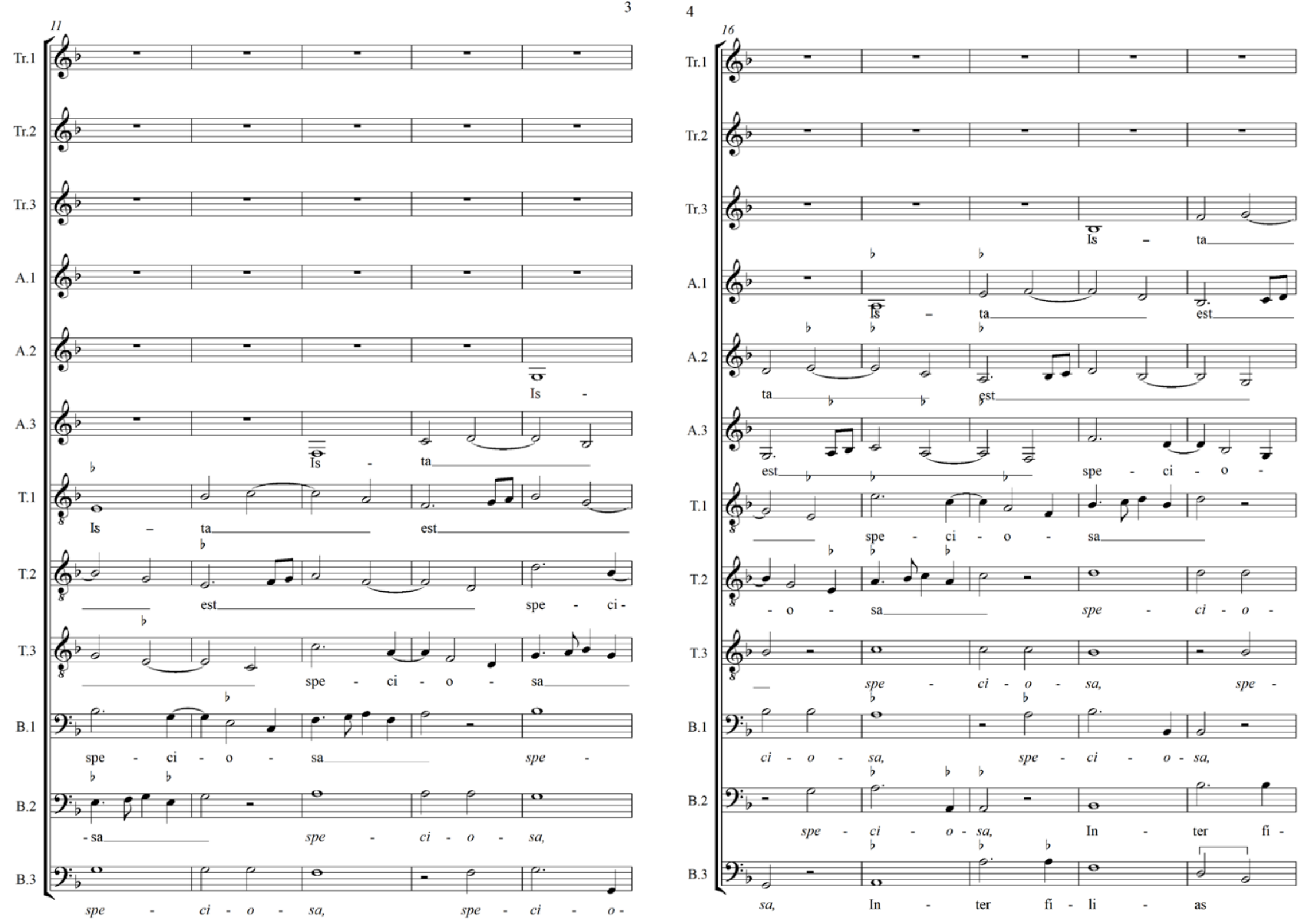

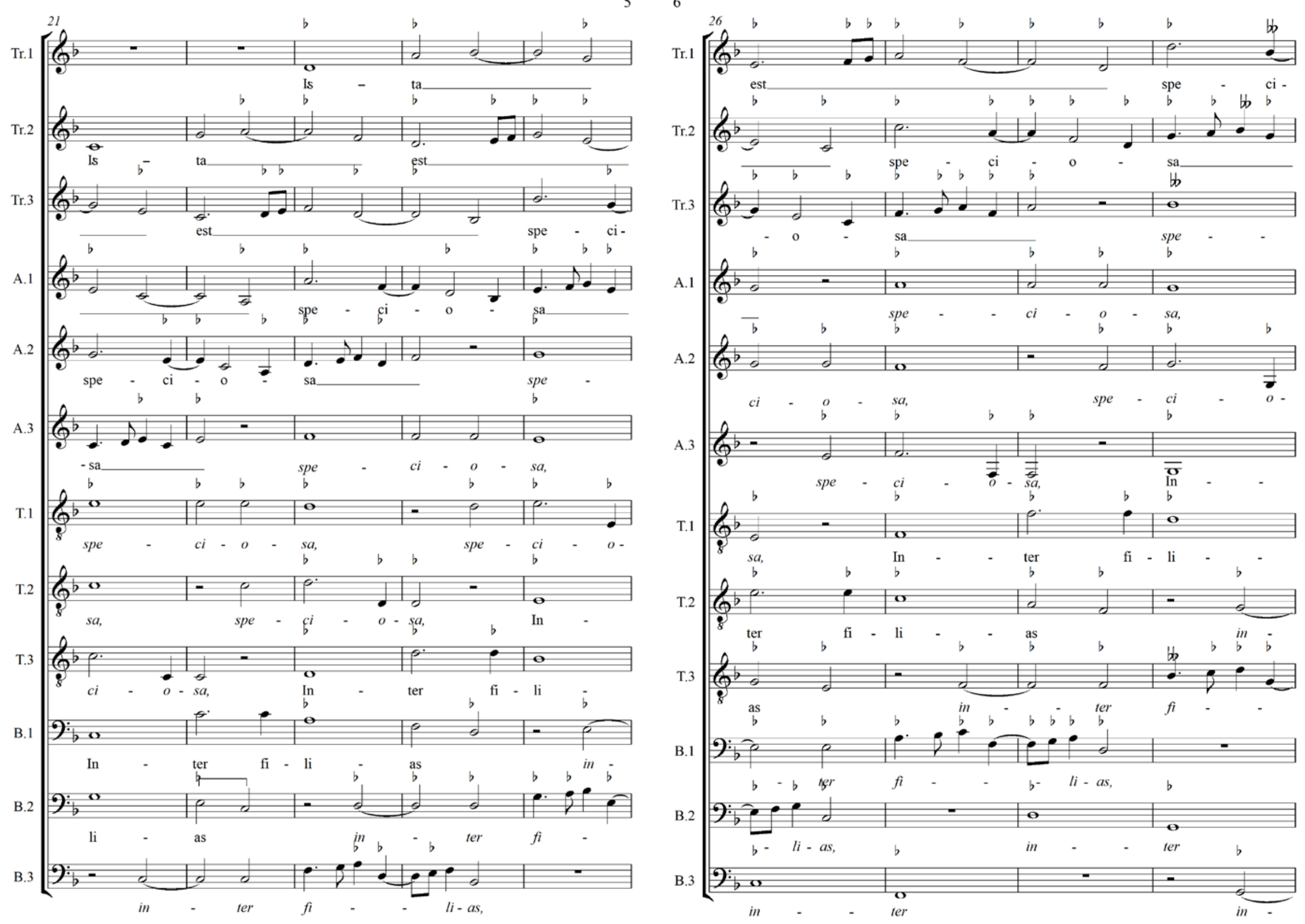

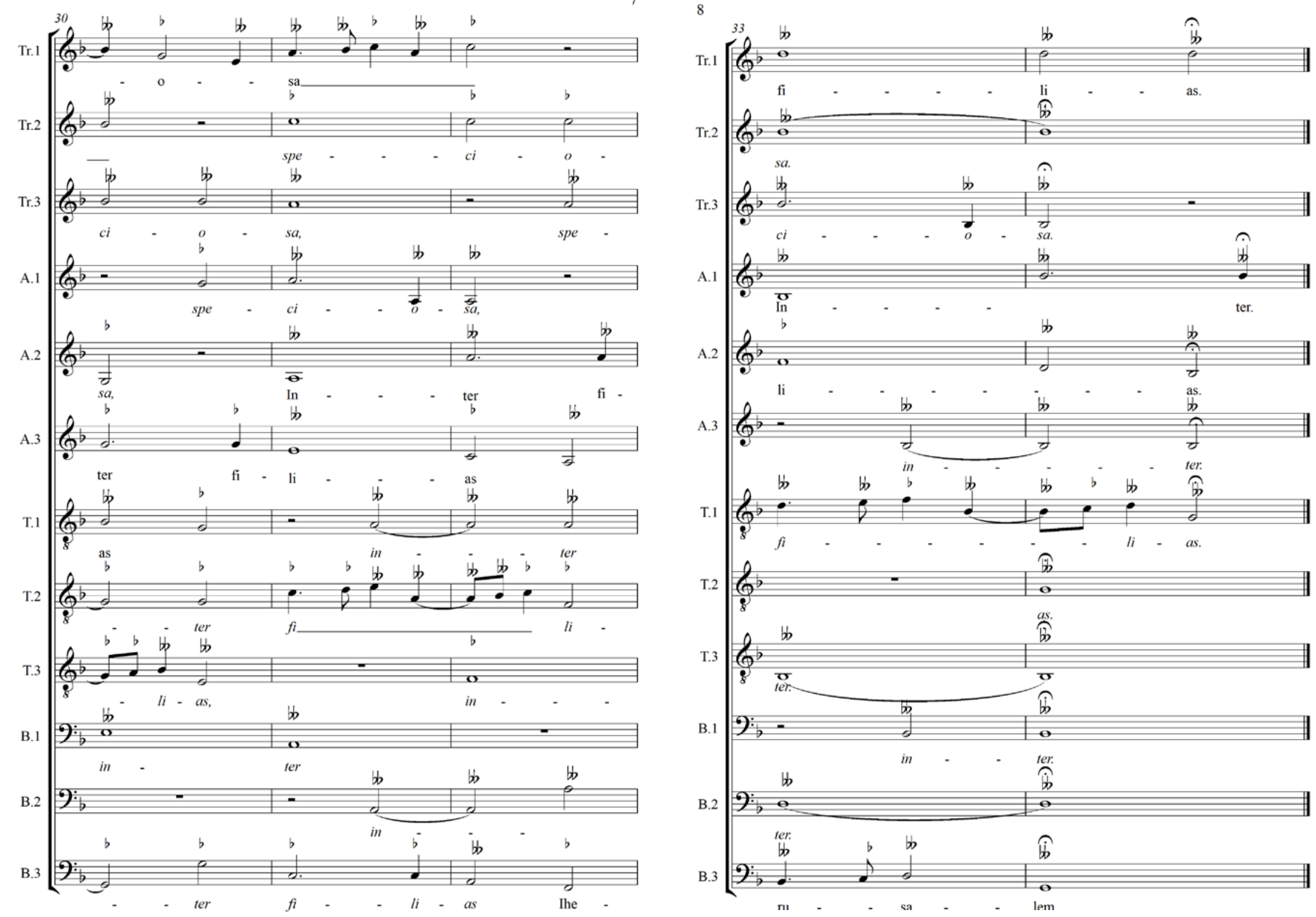


\begin{tabular}{|c|c|c|c|}
\hline $\begin{array}{l}\text { Antoine de Févin (c. 1470- } \\
\text { 1511/12) }\end{array}$ & 21 & $\begin{array}{l}\text { by } 1506 ; d . \\
1511 / 12\end{array}$ & Priest and singer in service of King Louis XII \\
\hline $\begin{array}{l}\text { Josquin des Prez (c. 1450- } \\
\text { 1521) }\end{array}$ & 5 & $\begin{array}{l}1475-80 \\
1480-83 \\
1498-1500 ?\end{array}$ & $\begin{array}{l}\text { Singer for René, duke of Anjou (uncle of King Louis XI) } \\
\text { Singer for Louis XI (Ste-Chapelle, Paris) } \\
\text { Connections with the court of King Louis XII }\end{array}$ \\
\hline $\begin{array}{l}\text { Jean Mouton (bef. 1459- } \\
\text { 1522) }\end{array}$ & 4 & $\begin{array}{l}1502 / 1509-14 \\
1514 \\
1515-d .1522\end{array}$ & $\begin{array}{l}\text { Magister in chapel of Queen Anne of Brittany } \\
\text { Chapel of King Louis XII? } \\
\text { Chapel of King Francis I }\end{array}$ \\
\hline $\begin{array}{l}\text { Jean Richafort (c. 1480-after } \\
\text { 1547) }\end{array}$ & 2 & $\begin{array}{l}1512 \\
\text { before } 1515 \\
1515-16\end{array}$ & $\begin{array}{l}\text { Received benefice in Brittany through agency of French crown } \\
\text { Composed Consolator captivorum for Louis XII } \\
\text { Chapel of King Francis I }\end{array}$ \\
\hline $\begin{array}{l}\text { Robert de Févin/Antoine de } \\
\text { Févin }\end{array}$ & 2 & Before 1516-18 & $\begin{array}{l}\text { Robert de Févin, brother of Antoine de Févin, apparently master } \\
\text { of Savoy ducal chapel; probably deceased by 1516-18 }\end{array}$ \\
\hline [no attribution]/‘Hyllayre’ & 1 & $\begin{array}{l}1505-9 \\
1510-15 \\
1519-20\end{array}$ & $\begin{array}{l}\text { Hilaire Bernonneau held a canonicate at St-Sauveur, Blois } \\
\text { Hilaire Bernonneau's service as chapelmaster for Louis XII } \\
\text { Bernonneau’s service as a Valet de chambre for King Francis I }\end{array}$ \\
\hline $\begin{array}{l}\text { ‘A.de fevin’/Pierrequin } \\
\text { Thérache (1470-1528) }\end{array}$ & 1 & ? & $\begin{array}{l}\text { Verbum bonum composed by Thérache, who has no known } \\
\text { direct links to the French royal court, but served the ducal court } \\
\text { of Lorraine 1492-1527 }\end{array}$ \\
\hline 'Fevin’/‘N. le Petit’' & 1 & $?$ & $\begin{array}{l}\text { 'Ninot' [Jean] le Petit has no known links to the French royal } \\
\text { court. He worked at Langres cathedral 1506-29 }\end{array}$ \\
\hline Johannes Brunet & 1 & ? & $\begin{array}{l}\text { Probably a Breton priest, in Rome 1486-93; d. } 1515 \text { at St- } \\
\text { Mathieu-de-Finistère, Brittany }\end{array}$ \\
\hline Io. Boytel & 1 & ? & Maître Jean Boitel was a vicar at the cathedral of Tours in 1503 \\
\hline Jacob Obrecht (1457-1505) & 1 & ? & None known; Obrecht travelled in France 1492-93 \\
\hline
\end{tabular}


Note. For the original orthography of the names of these composers, see Appendix I. 
Table 2 Gathering structure of music folios in MS 1760

\begin{tabular}{|c|c|c|c|c|c|}
\hline $\begin{array}{c}\text { Gathering } \\
1 \\
\end{array}$ & Fols. $^{1}$ & $\begin{array}{l}\text { Piece (according to } \\
\text { tabula foliation) }^{2}\end{array}$ & $\begin{array}{c}\text { Gathering } \\
5 \\
\end{array}$ & Fols. & Piece \\
\hline[ & $\begin{array}{l}4 \\
\text { I } \\
\text { II } \\
\text { III } \\
\text { IIII } \\
\text { V } \\
\text { VI } \\
\text { VII }\end{array}$ & $\begin{array}{l}\text { [empty staves on recto and verso] } \\
\text { Ave Maria }\left[\mathrm{I}^{\mathrm{r}}\right] \text {, Que est ista }\left[\mathrm{I}^{\mathrm{r}}\right] \\
\text { Ista est }\left[\mathrm{I}^{\mathrm{v}}\right] \text {, Dulcis amica }(a 3)\left[\mathrm{II}^{\mathrm{r}}\right] \\
\text { Dei genitrix ( } a \text { 4) } \\
\text { Verbum bonum }(a \text { 4) } \\
\text { Suscipe verbum }(a \text { 4) }\end{array}$ & $\bar{E}$ & $\begin{array}{l}\text { XXXII } \\
\text { XXXIII } \\
\text { XXXIIII } \\
\text { XXXV } \\
\text { XXXVI } \\
\text { XXXVII } \\
\text { XXXVIII } \\
\text { XXXIX[1] }\end{array}$ & $\begin{array}{l}\text { Zay. } 3^{\mathrm{a}} \text { lectio (a 4) } \\
\text { Quam pulchra es ( } a \text { 4) } \\
\text { [Benedicite] Dominus ( } a \text { 4) } \\
\text { Sufficiebat nobis (a 4) } \\
\text { O preclara stella maris (a 3) }\end{array}$ \\
\hline $\begin{array}{c}\text { Gathering } \\
2 \\
\end{array}$ & & & $\begin{array}{c}\text { Gathering } \\
6 \\
\end{array}$ & & \\
\hline[ & $\begin{array}{l}\text { VIII } \\
\text { IX } \\
\text { X } \\
\text { XI } \\
\text { XII } \\
\text { XIII } \\
\text { XIIII } \\
\text { XV }\end{array}$ & $\begin{array}{l}\text { O admirabile commercium ( } a \text { 4) } \\
\text { Quando natus est }(a \text { 4) } \\
\text { Rubum quem }(a \text { 4) } \\
\text { Germinavit radix }(a \text { 4) } \\
\text { Ecce Maria genuit }(a \text { 4) }\end{array}$ & $\Gamma$ & $\begin{array}{l}\text { XXXIX[2] } \\
\text { XL } \\
\text { XLI } \\
\text { XLII } \\
\text { XLIII } \\
\text { XLIIII } \\
\text { XLV } \\
\text { XLVI }\end{array}$ & $\begin{array}{l}\text { Dulcis mater dulci nato }(a \text { 3) } \\
\text { Ave Maria gratia dei plena (a 3) } \\
\text { Inclita pura sanctissima }(a \text { 3) } \\
\text { Nigra sum sed formosa }(a \text { 3) }\end{array}$ \\
\hline $\begin{array}{c}\text { Gathering } \\
3\end{array}$ & & & $\begin{array}{c}\text { Gathering } \\
7\end{array}$ & & \\
\hline[ & $\begin{array}{l}\text { XVI } \\
\text { XVII } \\
\text { XVIII } \\
\text { XIX } \\
\text { XX } \\
\text { XXI } \\
\text { XXII } \\
\text { XXIII }\end{array}$ & $\begin{array}{l}\text { Ave Maria gratia dei (a 4) } \\
\text { Ecce Maria genuit (a 4) } \\
\text { Sub tuum presidium (a 4) } \\
\text { Sancta Trinitas (a 4) } \\
\text { Nobilis progenie }(a \text { 4) }\end{array}$ & {[} & $\begin{array}{l}\text { XLVII } \\
\text { XLVIII } \\
\text { XLIX } \\
\text { L } \\
\text { LI } \\
\text { LII } \\
\text { LIII } \\
\text { LIIII }\end{array}$ & $\begin{array}{l}\text { Parce domine populo tuo (a 3) } \\
\text { On a mal dit de mon amy (a 3) } \\
\text { Tres doulce dame (a 3) } \\
\text { Mauditz soient (a 3) } \\
\text { Helas je suys mary (a 3) } \\
\text { Je le laire puys ( } a \text { 3) } \\
\text { Chacun maudit (a 3) }\end{array}$ \\
\hline $\begin{array}{c}\text { Gathering } \\
4\end{array}$ & & & $\begin{array}{c}\text { Gathering } \\
8\end{array}$ & & \\
\hline[ & $\begin{array}{l}\text { XXIIII } \\
\text { XXV } \\
\text { XXVI } \\
\text { XXVII } \\
\text { XXVIII } \\
\text { XXIX } \\
\text { XXX } \\
\text { XXXI }\end{array}$ & $\begin{array}{l}\text { Adiutorium nostrum (a 4) } \\
\text { Aleph. Prima lectio (a 4) } \\
\text { Gimel. 2a lectio }(a \text { 3) }\end{array}$ & {[} & $\begin{array}{l}\text { LV } \\
\text { LVI } \\
\text { LVII } \\
\text { LVIII } \\
\text { LIX } \\
\text { LX } \\
\text { LXI } \\
\text { LXII }\end{array}$ & $\begin{array}{l}\text { En amours na sinon ( } a \text { 3) } \\
\text { Petite camusette ( } a \text { 3) } \\
\text { Fors seullement }(a \text { 3) } \\
\text { Il faict bon ayme loyselet ( } a \text { 3) }\end{array}$ \\
\hline
\end{tabular}

${ }^{1}$ All folio numbers appear on top right recto.

${ }^{2}$ After fol. $\mathrm{II}^{\mathrm{r}}$ all pieces start on the verso side of the opening given by the tabula foliation (e.g., Dei genitrix begins on the opening consisting of fols. $\mathrm{II}^{\mathrm{v}}$ and $\mathrm{III}^{\mathrm{r}}$ ). The canonic melody for Ista est speciosa appears in its entirety on fol. $\mathrm{I}^{\mathrm{v}}$. 


\begin{tabular}{|c|c|c|c|c|c|}
\hline $\begin{array}{c}\text { Gathering } \\
9 \\
\end{array}$ & Fols. & Piece & $\begin{array}{c}\text { Gathering } \\
11\end{array}$ & Fols. & Piece \\
\hline$\sqrt{[}$ & $\begin{array}{l}\text { LXIII } \\
\text { LXIIII } \\
\text { LXV } \\
\text { LXVI } \\
\text { LXVII } \\
\text { LXVIII } \\
\text { LXIX } \\
\text { LXX }\end{array}$ & $\begin{array}{l}\text { Iayme bien mon amy ( } a \text { 3) } \\
\text { Adieu solas }(a \text { 3) } \\
\text { Faulte dargent }(a \text { 3) } \\
\text { Iay veu la beaute }(a \text { 3) } \\
\\
\text { Il mest advis ( } a \text { 3) } \\
\text { Dieu gard de mal }(a \text { 3) }\end{array}$ & $\overline{[}$ & $\begin{array}{l}\text { LXXIX } \\
\text { iiiii }^{\mathrm{XX}} \\
\mathrm{iiii}^{\mathrm{XXI}} \\
\mathrm{iiii}^{\mathrm{XXII}} \\
\mathrm{iiiii}^{\mathrm{XXIII}} \\
\text { iiiii }^{\mathrm{XXIIII}} \\
\text { iiiii }^{\mathrm{XXV}} \\
\text { iiii }^{\mathrm{XXVI}}\end{array}$ & $\begin{array}{l}\text { Celle qui ma demande (a 3) } \\
\text { Hellas madame (a 3) } \\
\text { Naymes james (a 4) } \\
\text { Damours je suys (a 5) } \\
\text { Sy jeusse marion }(a \text { 4) } \\
\text { Consommo la vita }(a 4)^{4}\end{array}$ \\
\hline \multicolumn{6}{|l|}{$\begin{array}{c}\text { Gathering } \\
10\end{array}$} \\
\hline$\sqrt{5}$ & $\begin{array}{l}\text { LXXI } \\
\text { LXXII } \\
\text { LXXIII } \\
\text { LXXIIII } \\
\text { LXXV } \\
\text { LXXVI } \\
\text { LXXVII } \\
\text { LXXVIII }\end{array}$ & $\begin{array}{l}\text { Iay mys mon cueur ( } a \text { 3) } \\
\text { Ie voys je viens ( } a \text { 3) } \\
\text { Pastourelle dieu }(a \text { 3) } \\
\text { Pour avoir faict au gre ( } a \text { 3) } \\
\text { En ce joly temps ( } a \text { 3) }\end{array}$ & & & \\
\hline
\end{tabular}

3 'Sy Iavoys marion' in the tabula.

${ }^{4}$ Listed as fol. iiii ${ }^{\mathrm{XXv}}$ in the tabula. The song appears in its entirety on fol. iiii ${ }^{\mathrm{XXVIv}}$. 
Table 3 Content and presumed structure of non-music folios at the beginning and end of MS 1760

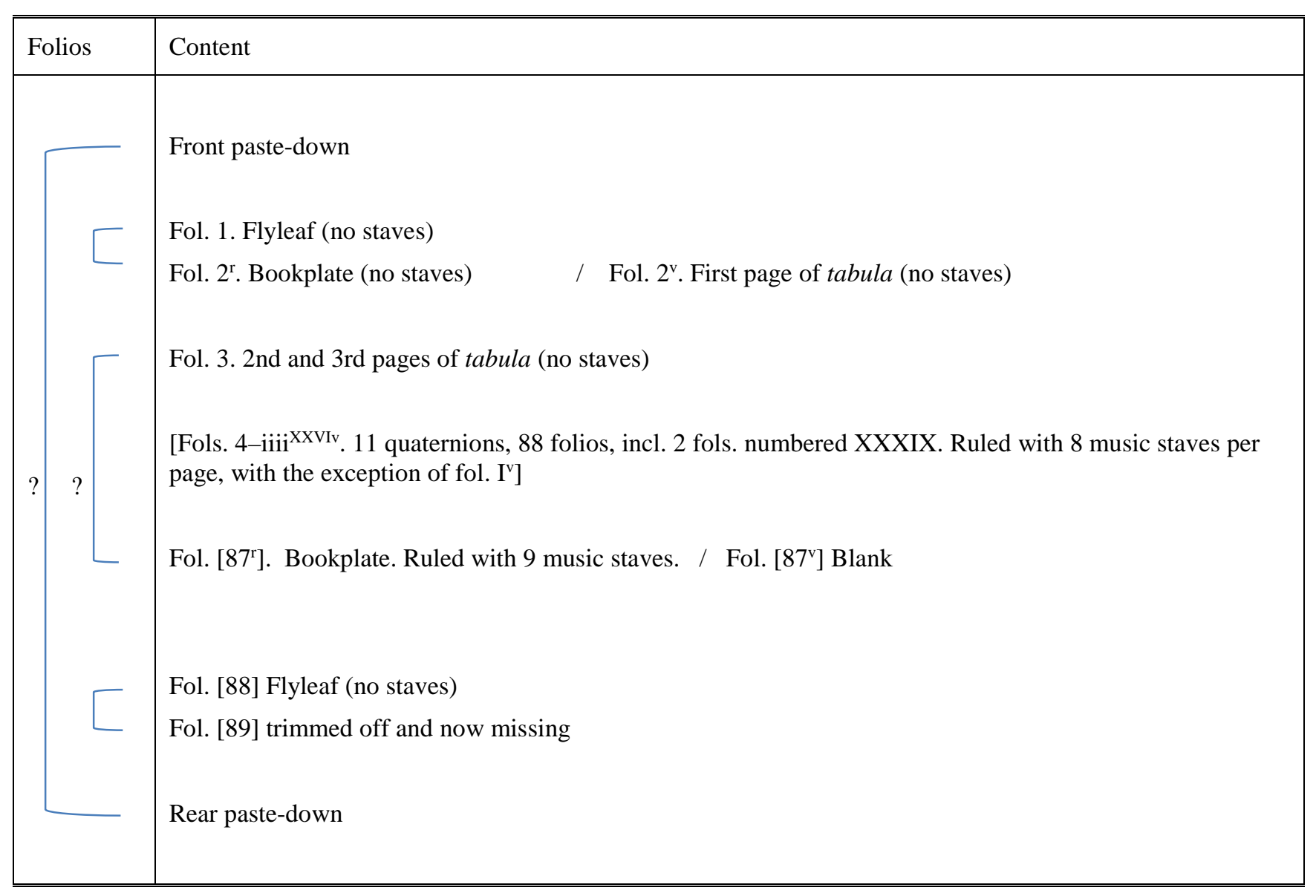

